\title{
Emergency Department Care Survey
}

Güven Bektemür', Nurgül Osmanbeyoğlu², Başar Cander ${ }^{3}$

'Istanbul Beyoglu Public Hospitals Union, Chief Executive Officer, Istanbul, Turkey

${ }^{2}$ Sisli Hamidiye Etfal Teaching Hospital, Deputy Chief of Staff, Istanbul, Turkey

${ }^{3}$ Clinic of Emergency Medicine, Okmeydani Training and Research Hospital, Istanbul, Turkey

\section{ISTANBUL BEYOGLU PUBLIC HOSPITALS UNION}

Through its Healthcare Transformation Program, Turkey has successfully introduced health system changes to provide its citizens with the right to health. One of the most important changes that was brought about by the Program was the rearrangement of the organizational structure of the Ministry of Health. Within this framework, The Turkish Public Hospitals Union was founded and commissioned to carry out the operations of secondary and tertiary level healthcare facilities.

The establishment of the Union has aimed to provide savings, increase productivity, distributes human resources equally and provide cooperation between partners to carry out equal, high quality and efficient care delivery.

As a result, 89 hospital unions were launched countrywide. Secondary and tertiary level public healthcare facilities within the same province have been unified under the management of a Public Hospitals Union. More than one Union has been established in the same province if the size of the service provided was appropriate. There are 6 such Unions serving in the city of Istanbul and Beyoglu Public Hospitals Union (BKHB) is one of them. It was established in November 2012 and encompasses 11 hospitals. The union mainly serves a population of 2.3 Million in the Beyoglu, Şişli, Beşiktaş and Sarıyer local municipalities; although patients from other districts are free to apply. $63 \%$ of the people residing in this region have at least once visited our hospitals. Approximately $25 \%$ of patients come from other districts.

There are 5 Teaching Hospitals (TH), 5 secondary level Public Hospitals (PH) and 1 Oral and Dental Health Hospital within our union and the union is responsible for providing health services to the citizens efficiently. Our union is also positioned as the Coordinating Union for Istanbul and manages Human Resource and Medical Services planning for the whole city.

\section{OUR HOSPITALS}

\section{Okmeydanı Teaching Hospital}

Okmeydanı Teaching Hospital started serving the city as Beyoglu Hospital with 1000 registered beds and got authorized for residency training in all its clinics in 1979. In 1983, it was registered as SSK Okmeydanı Teaching Hospital and in 2005 its control was transferred to the Ministry of Health. It has a special pediatric emergency department, serving only for patients under the age of 15 . It has an enclosed area of $60.370 \mathrm{~m}^{2}, 753$ registered beds and 2640 employees.

\section{Şişli Hamidiye Etfal Teaching Hospital}

The hospital was established in June 1899 as Hamidiye Etfal Hospital after the death of Sultan II. Abdulhamid's eight month old daughter, Sultan Hatice. It is the first public hospital that started medical residency training. Medical specialty training that had started with 5 physicians in 1904 has expanded in different fields. Nurses, assistant nurses, midwives, laboratory worker and different technicians in various specialties were trained in the hospital since 1930.

The orthopedics and pediatrics clinics of Istanbul Medical School were located here, between 1933 and 1949. The hospital, being one of the outstanding teaching hospitals in Turkey, still provides training in 21 medical specialties. There are 3 separate emergency departments for adults, children, and gynecology and obstetrics patients. It has an enclosed area of $83704 \mathrm{~m}^{2}, 677$ registered beds and 2.498 employees.

\section{Gaziosmanpaşa Taksim Teaching Hospital}

The hospital started serving under the name of Taksim Hospital in 1969 but its history dates back to 1910's, when it served as a nursing home. The hospital has moved to its new building in Gaziosmanpaşa, at the end of 2012. It has an enclosed area of $61193 \mathrm{~m}^{2}, 300$ registered beds and 1.384 employees.

\section{Metin Sabancı Baltalimanı Orthopedic Teaching Hospital}

The hospital was opened to service by the Ministry of Health in 1944 under the name of Bone and Joint Tuberculosis Hospital. Its name was changed as Baltalimanı Orthopedic Hospital in 1960. It was transformed into specialty teaching hospital by the Ministry of Health in December 3, 2001 and it is the first specialty Teaching Hospital in orthopedics and traumatology. It has an enclosed area of $15236 \mathrm{~m}^{2}, 136$ registered beds and 537 employees. It has an emergency department, however is not included in our report because it is a specialty hospital.

\section{Prof. Dr. Reşat Belger Beyoğlu Ophthalmology Teaching Hospital}

During the cholera epidemic in 1865, a shop was rented in Galata Kuledibi and the patients were cared here. Thus, the hospital was founded and took the name of Beyoglu Municipality Hospital in 1948, with 102 beds. In 1998, its management was transferred to the Ministry of Health and transformed into specialty Teaching Hospital training physicians in Ophthalmology. It is the first and only ophthalmology hospital in Istanbul. It has an enclosed area of $10301 \mathrm{~m}^{2}$, 
100 registered beds and 389 employees. It has an emergency department, however is not included in our report because it is a specialty hospital.

\section{Eyüp Public Hospital}

The hospital was founded as Eyüp SSK Hospital in 1952 and its name was changed as Eyüp Public Hospital in 2005. It serves as a secondary level public hospital with its buildings and its district outpatient clinics. It has an enclosed area of $19155 \mathrm{~m}^{2}, 140$ registered beds and 576 employees.

\section{Sarıyer İstinye Public Hospital}

The hospital was founded in 1948, as a two-floor building, with its first floor being Tuberculosis Control Dispensary and the second floor being a health center with 10 beds. It moved to its current building in 1998 and it serves as a secondary level public hospital. It has an enclosed area of $8935 \mathrm{~m}^{2}, 128$ registered beds and 442 employees.

\section{Kâğıthane Public Hospital}

The hospital was founded as an ambulatory care clinic in 2005 and started providing inpatient care since 2007. It serves as a secondary level public hospital. It has an enclosed area of $11073 \mathrm{~m}^{2}, 51$ registered beds and 361 employees.

\section{Sarıyer İsmail Akgün Public Hospital}

The hospital was built by a philanthropist named İsmail Akgün and started serving as a dispensary in 1948. Its management was transferred to the Ministry of Health in 1985 and continued serving as a secondary level public hospital in Sarıyer district. It has an enclosed area of $3344 \mathrm{~m}^{2}, 40$ registered beds and 223 employees.

\section{Beşiktaş Sait Çiftçi Public Hospital}

The hospital was built by a philanthropist named Sait Çiftçi in 1972 and its ownership was transferred to municipal authority as a dispensary. Its control was transferred to the Ministry of Health in 1982. It has been serving under the name of Beşiktaş Sait Çiftçi Public Hospital since 2010. The hospital doesn't have inpatient clinics and is not included in our report because it doesn't have 24 hour serving emergency department. It has an enclosed area of $4180 \mathrm{~m}^{2}$ and 163 employees.

\section{Okmeydanı Oral and Dental Health Hospital}

The hospital was founded as Şişli Etfal Teaching Hospital Dental Clinic and became a separate institution as Şişli Oral and Dental Health Center in April 27, 1999. It moved to its separate and current building in 2003. It is one of the biggest hospitals serving as an oral and dental health hospital in Turkey. It has an enclosed area of $12.100 \mathrm{~m}^{2}$, 12 registered beds and 582 employees. It has an emergency department, however is not included in our report because it is a specialty hospital.

\section{MATERIALS AND METHODS}

Hospital and Emergency Department visit numbers for Turkey and Istanbul are obtained from Directorate General of Health Services Statistics, Analysis and information Systems via official correspondence.

We conducted our detailed Emergency Department analysis based on the data obtained from the hospitals managed by Beyoglu
Public Hospitals Union. All data are obtained from Beyoglu Decision Support System (DSS) which retracts data from 11 different Hospital Management and Information System (HMIS).We used the electronic records of 4 secondary level and 3 tertiary level public hospitals for year 2014. 3 of the specialty hospitals and one secondary level acute care hospital were excluded because their emergency department did not provide full range of conventional emergency care. We analyzed variables including but not limited to number of visits, age, sex, triage category, arrival time and day, admission rate and diagnosis according to ICD 10 code.

While analyzing the data, we calculated descriptive statistics such as mean (M), standard deviation, maximum value (Max), minimum value (Min). Then data was controlled to check whether it was suitable for "Normal Distribution". Then we decided whether or not to apply parametric or nonparametric test.

The significance level ( $p$ ) is taken as \% $5(0.05)$ and two tests are applied; "independent samples t test" (parametric test) and "Mann Whithey'u test". ANOVA test is applied when the data include more than two groups. "Coefficient of correlation" is used to measure the relationship between the variables. We performed statistical analysis using "IBM SPSS Statistic Version 22".

\section{EMERGENCY CARE IN TURKEY}

As a result of the Health Transformation Program and the concurrent Social Security Reform started in 2003, access to healthcare has improved and increased across the country. Number of visits to a healthcare provider per person has risen dramatically especially after 2003. Doctor visit per capita increased from 3.2 in 2002 to 8.2 in 2011, even surpassing the OECD average of 6.7 (Table 1).

When we look at Table 1, we see that the number of visits tend to increase continuously between 2002 and 2013. Although the number of primary care visits decreased in 2010, 2011 and 2013, secondary and tertiary care visits per patient tended to continue climbing. There isn't any significant difference in the distribution of visits per patient between 2002 and 2013; the average is $36.9 \%$ for primary care and $63.1 \%$ for secondary and tertiary care.

The rate of increase in primary care visits per patient between 2002 and 2013 is $164 \%$ and $165 \%$ for secondary and tertiary care. The most dramatic increase in doctor visits is in Emergency Departments (ED). Per capita Emergency Department visits (EDV) was 0.29 in 2002; however it reached to 1.31 with an increase of $352 \%$ in 2013 (Table 2, 3). When we compare this with the international data we see that the EDV per patient is 0.4 in the US and Britain in 2013, and EDV is quite high in our country (1).

When we analyze hospital visits for the whole country, we see that the growth rate of visits to ED shows a faster increase than the others (Figure 1, Table 4). The highest increase was at the time when Social Insurance Institution Hospitals and Public Hospitals merged and the hospitals of the Ministry of Health started providing service to the blue-collar workers and their families. As a result of this upsurge, the number of visits to ED throughout Turkey surpassed the population and reached to over 100 million (Table 5). We think the reason for this increase was because patients were able to use the ED of all the hospitals of if they needed immediate attention without any need for referral including private hospitals with and without Social Security Institution contracts for free. 
EDV throughout Turkey in the hospitals of the Ministry of Health has increased continuously until 2009 (Table 6). In 2002, $16.79 \%$ of the visits to the hospitals of the Ministry of Health were emergency patients, and in 2009 the rate went up to $31.76 \%$. Similarly, the rate of emergency patients in private hospitals went up dramatically from $5.65 \%$ to $16.92 \%$ in 2013 (Table 6). The main reason for this was the increase in the number of private hospitals. There was a slight decrease from $15.09 \%$ to $13.26 \%$ of EDV in university hospitals (Figure 2 ).

This rate didn't change dramatically in the hospitals of the Ministry of Health in Istanbul during the same years and was approximately $25 \%$ which went up to $26.83 \%$ in 2013 . A decrease was seen for the same years in EDV in the university hospitals and private hospitals of Istanbul (Table 7, 8, 9). The reason may be the number of private hospitals increased more rapidly in Anatolia rather than in Istanbul.

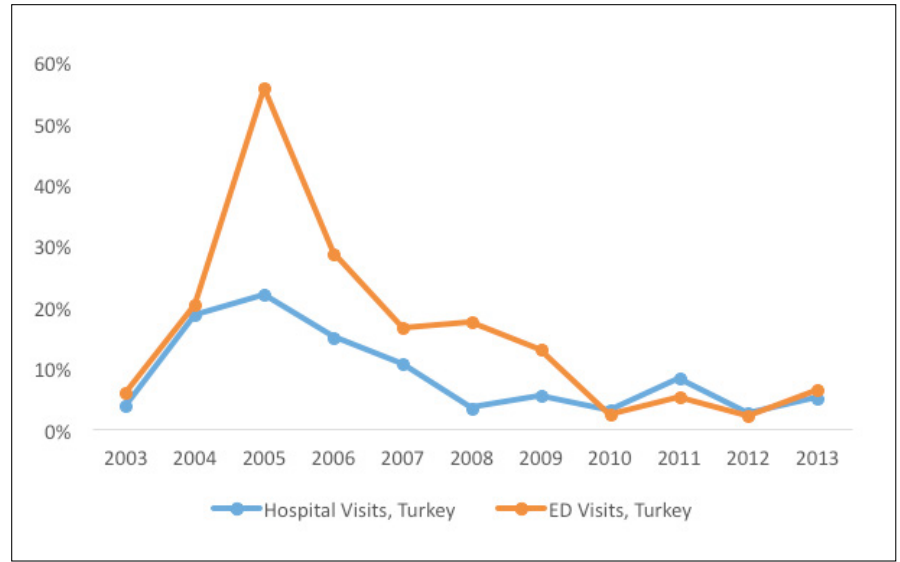

Figure 1. Annual Rate of Increase in Hospital and Emergency Department visits, Turkey

Table 1. Number of Doctor Visits per Capita, Turkey 2002-2013

\begin{tabular}{|c|c|c|c|c|c|c|c|c|c|c|c|c|}
\hline Type of institution & 2002 & 2003 & 2004 & 2005 & 2006 & 2007 & 2008 & 2009 & 2010 & 2011 & 2012 & 2013 \\
\hline Primary care & 1.10 & 1.30 & 1.30 & 1.70 & 1.90 & 2.20 & 2.50 & 2.80 & 2.70 & 3.30 & 3.10 & 2.90 \\
\hline $\begin{array}{l}\text { Secondary and } \\
\text { Tertiary Care }\end{array}$ & 2.00 & 2.10 & 2.40 & 3.00 & 3.40 & 3.90 & 4.20 & 4.50 & 4.60 & 4.90 & 5.10 & 5.30 \\
\hline $\begin{array}{l}\text { Emergency } \\
\text { Department }\end{array}$ & 0.29 & 0.31 & 0.38 & 0.58 & 0.74 & 0.86 & 0.97 & 1.11 & 1.14 & 1.23 & 1.24 & 1.31 \\
\hline Total & 3.10 & 3.40 & 3.70 & 4.70 & 5.30 & 6.10 & 6.70 & 7.30 & 7.30 & 8.20 & 8.200 & 8.20 \\
\hline
\end{tabular}

Table 2. Number of Emergency Department Visits Per Capita, Turkey 2002-2013

\begin{tabular}{|c|c|c|c|c|c|c|c|c|c|c|c|c|}
\hline Type of institution & 2002 & 2003 & 2004 & 2005 & 2006 & 2007 & 2008 & 2009 & 2010 & 2011 & 2012 & 2013 \\
\hline Ministry of Health & 0.27 & 0.28 & 0.34 & 0.52 & 0.67 & 0.77 & 0.90 & 1.00 & 1.01 & 1.04 & 1.05 & 1.11 \\
\hline University & 0.02 & 0.02 & 0.02 & 0.02 & 0.02 & 0.03 & 0.02 & 0.03 & 0.04 & 0.04 & 0.05 & 0.05 \\
\hline Private & 0.005 & 0.01 & 0.02 & 0.04 & 0.05 & 0.06 & 0.04 & 0.08 & 0.09 & 0.14 & 0.13 & 0.15 \\
\hline Total & 0.29 & 0.31 & 0.38 & 0.58 & 0.74 & 0.86 & 0.97 & 1.11 & 1.14 & 1.23 & 1.24 & 1.31 \\
\hline
\end{tabular}

Table 3. Number of Emergency Department Visits Per Capita, Istanbul 2002-2013

\begin{tabular}{|c|c|c|c|c|c|c|c|c|c|c|c|c|}
\hline Type of institution & 2002 & 2003 & 2004 & 2005 & 2006 & 2007 & 2008 & 2009 & 2010 & 2011 & 2012 & 2013 \\
\hline Ministry of Health & 0.32 & 0.32 & 0.35 & 0.38 & 0.46 & 0.49 & 0.55 & 0.59 & 0.61 & 0.66 & 0.69 & 0.78 \\
\hline University & 0.03 & 0.03 & 0.02 & 0.03 & 0.03 & 0.03 & 0.04 & 0.05 & 0.04 & 0.04 & 0.04 & 0.04 \\
\hline Private & 0.04 & 0.04 & 0.05 & 0.06 & 0.08 & 0.08 & 0.08 & 0.08 & 0.09 & 0.10 & 0.10 & 0.10 \\
\hline Total & 0.38 & 0.39 & 0.42 & 0.47 & 0.57 & 0.60 & 0.67 & 0.72 & 0.74 & 0.81 & 0.83 & 0.92 \\
\hline
\end{tabular}

Table 4. Number of Hospital Visits, Turkey 2002-2013

\begin{tabular}{|c|c|c|c|c|c|c|c|c|c|c|c|c|}
\hline Type of institution & 2002 & 2003 & 2004 & 2005 & 2006 & 2007 & 2008 & 2009 & 2010 & 2011 & 2012 & 2013 \\
\hline Ministry of Health & $109,793,128$ & $113,934,570$ & $135,169,229$ & $164,758,149$ & $189,422,137$ & $209,630,370$ & $216,723,712$ & $228,279,139$ & $235,172,924$ & $254,342,943$ & $260,974,401$ & $274,200,691$ \\
\hline University & $8,823,361$ & $9,637,840$ & $10,685,275$ & $11,493,879$ & $12,588,872$ & $15,025,079$ & $18,290,800$ & $19,364,865$ & $20,098,754$ & $24,437,107$ & $27,080,436$ & $29,985,697$ \\
\hline Private & $5,697,170$ & $5,123,899$ & $6,187,371$ & $9,533,509$ & $15,529,416$ & $24,485,650$ & $38,688,313$ & $47,618,186$ & $47,712,540$ & $59,069,486$ & $66,582,098$ & $66,933,495$ \\
\hline Total & $124,313,659$ & $128,696,309$ & $152,041,875$ & $185,785,537$ & $217,540,425$ & $249,141,099$ & $273,702,825$ & $295,262,190$ & $302,984,218$ & $337,849,536$ & $354,636,935$ & $371,119,883$ \\
\hline
\end{tabular}


Based on the numbers retrieved from the DSS, the hospitals appertained to our union provided ambulatory care to 5,678,753 patients and emergency healthcare to $2,081,138$ patients in 2013 . Thus, the rate of EDV went in line with the average of Istanbul which is $27 \%$. About $16 \%$ of the EDV in Istanbul and 19\% of EDV to the hospitals of the Ministry of Health were made to the hospitals of our Union. $82 \%$ of the patients visiting to Emergency Department are the ones residing within our region.

When we look at the visits to the hospitals in general, approximately $74 \%$ of the patients in Turkey are cared by the hospitals of the Ministry of Health and this ratio is $66 \%$ in Istanbul (Table 10). In contrast, $85 \%$ of all emergency care throughout Turkey and Istanbul are provided by the hospitals of the Ministry of Health (Table 11, 12, 13, Figure 3). This shows that Turkish people prefer emergency healthcare in the hospitals of the Ministry of Health. We believe this is because people think they would have to make payment in private hospitals even though hospitals are not allowed to charge payment in ED and the illegal practices might be an issue.

As suggested in the statement published in 2009 by the Ministry of Health, a 3-level triage system has been commonly used in Turkey. In 3-level triage system, patients are categorized as emergent (red), urgent (yellow) and non-urgent (green). Emergency care was totally free until 2012 for all patients. Currently the care is free for patients triaged as yellow or red including those without health insurance. A small copayment is charged for green category patients.

In Turkey, Emergency Medicine was first accepted as an area of specialization in 1993. It is stated in the Public Hospitals Almanac that

1124 Emergency Medicine Specialists has served countrywide as of 2014. Because the number of specialists in emergency medicine is not adequate, emergency care is usually provided by the general practitioners in secondary level $\mathrm{PH}$.

\section{CHARACTERISTICS OF EMERGENCY DEPARTMENT VISITS}

\section{Number of Emergency Department Visits}

In Table 14, we can see the hospital visit figures for 2014. Okmeydanı TH and İstinye PH's emergency visit rates are nearly 32\% and abo-

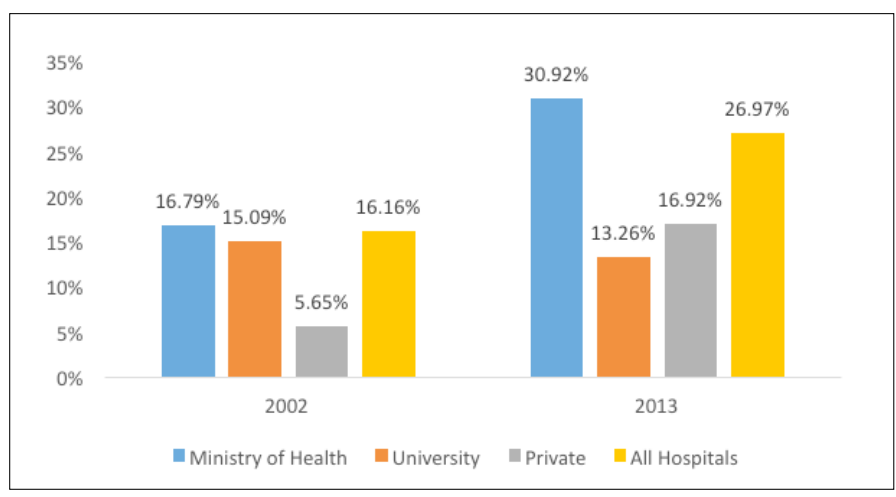

Figure 2. The Rate of Emergency Department Visits by Type of Institution, 2013

Table 5. Number of Emergency Department Visits, Turkey 2002-2013

\begin{tabular}{|c|c|c|c|c|c|c|c|c|c|c|c|c|}
\hline Type of institution & 2002 & 2003 & 2004 & 2005 & 2006 & 2007 & 2008 & 2009 & 2010 & 2011 & 2012 & 2013 \\
\hline Ministry of Health & $18,433,610$ & $19,512,127$ & $23,468,744$ & $36,520,482$ & 46,98 & $54,699,892$ & $64,227,137$ & 72,50 & 61 & $78,037,743$ & $79,672,782$ & 84,7 \\
\hline University & $1,331,356$ & דר 106 & & דרת 169 & (106 1026 & & & & $2,786,125$ & $3,330,028$ & & $3,976,656$ \\
\hline Private & ,929 & $1,243,16$ & 1,55 & $2,835,3$ & $3,343,84$ & 7,75 & $4,650,8$ & 5,4 & 6,96 & 10,4 & 10,2 & 11,32 \\
\hline Total & $0,086,895$ & $21,419,596$ & $26,346,204$ & $40,820,287$ & $51,955,730$ & $60,451,456$ & $70,886,871$ & $80,225,415$ & $83,995,802$ & $91,813,636$ & $93,491,395$ & $100,081,171$ \\
\hline
\end{tabular}

Source: Department of Statistics, Analytics and Information Systems, Ministry of Health, Turkey

Table 6. Rate of Emergency Department Visits within Total Hospital Visits (\%), Turkey 2002-2013

\begin{tabular}{|c|c|c|c|c|c|c|c|c|c|c|c|c|}
\hline Type of institution & 2002 & 2003 & 2004 & 2005 & 2006 & 2007 & 2008 & 2009 & 2010 & 2011 & 2012 & 2013 \\
\hline Ministry of Health & 16.79 & 17.13 & 17.36 & 22.17 & 24.80 & 26.09 & 29.64 & 31.76 & 31.57 & 30.68 & 30.53 & 30.92 \\
\hline University & 15.09 & 12.31 & 12.34 & 12.74 & 12.93 & 12.03 & 10.98 & 11.53 & 13.86 & 13.63 & 13.35 & 13.26 \\
\hline Private & 5.65 & 14.08 & 25.20 & 29.74 & 21.53 & 16.11 & 12.02 & 11.52 & 14.59 & 17.68 & 15.32 & 16.92 \\
\hline All Hospitals & 16.16 & 16.64 & 17.33 & 21.97 & 23.88 & 24.26 & 25.90 & 27.17 & 27.72 & 27.18 & 26.36 & 26.97 \\
\hline
\end{tabular}

Table 7. Number of Hospital Visits, Istanbul 2002-2013

\begin{tabular}{|c|c|c|c|c|c|c|c|c|c|c|c|c|}
\hline Type of institution & 2002 & 2003 & 2004 & 2005 & 2006 & 2007 & 2008 & 2009 & 2010 & 2011 & 2012 & 2013 \\
\hline Ministry of Health & $12,822,539$ & $13,784,321$ & $16,176,027$ & $17,856,927$ & $21,935,848$ & $24,671,874$ & $27,700,129$ & $31,336,312$ & $233,798,880$ & $37,000,862$ & $37,684,468$ & $41,345,527$ \\
\hline University & $1,175,894$ & $1,258,299$ & $1,253,666$ & $1,382,415$ & $1,411,665$ & $1,819,364$ & $2,344,067$ & $2,768,670$ & $2,877,526$ & $3,671,761$ & $3,894,829$ & $4,116,281$ \\
\hline Private & $3,168,623$ & $3,325,269$ & $3,491,835$ & $5,062,583$ & $6,708,973$ & $9,175,497$ & $12,653,780$ & $14,094,659$ & $913,469,869$ & $15,304,323$ & $15,464,378$ & $17,035,750$ \\
\hline Total & $17,167,056$ & $18,367,889$ & $20,921,528$ & $24,301,925$ & $30,056,486$ & $35,666,735$ & $42,697,976$ & $48,199,641$ & $50,146,275$ & $55,976,946$ & $57,043,675$ & $62,497,558$ \\
\hline
\end{tabular}


Table 8. Number of Emergency Department Visits, Istanbul 2002-2013

\begin{tabular}{|c|c|c|c|c|c|c|c|c|c|c|c|c|}
\hline Type of institution & 2002 & 2003 & 2004 & 2005 & 2006 & 2007 & 2008 & 2009 & 2010 & 2011 & 2012 & 2013 \\
\hline Ministry of Health & $3,205,635$ & $3,446,080$ & $4,044,007$ & $4,464,232$ & $5,483,962$ & $6,167,969$ & $6,925,032$ & $7,653,505$ & $8,070,829$ & $8,986,426$ & 9,590,983 & $11,093,825$ \\
\hline University & 258,697 & 276,826 & 275,807 & 304,131 & 310,566 & 400,260 & 515,695 & 611,140 & 582,071 & 606,722 & 621,384 & 505,080 \\
\hline Private & 380,235 & 465,538 & 628,530 & 759,387 & 939,256 & $1,009,305$ & $1,012,302$ & $1,080,718$ & $1,129,089$ & $1,414,802$ & $1,330,601$ & $1,414,717$ \\
\hline Total & $3,844,566$ & $4,188,444$ & $4,948,344$ & $5,527,751$ & $6,733,785$ & $7,577,533$ & $8,453,029$ & $9,345,363$ & $9,781,989$ & $11,007,950$ & $11,542,968$ & $813,013,622$ \\
\hline
\end{tabular}

Table 9. Rate of Emergency Department Visits within Total Hospital Visits (\%), Istanbul 2002-2013

\begin{tabular}{|c|c|c|c|c|c|c|c|c|c|c|c|c|}
\hline Type of institution & 2002 & 2003 & 2004 & 2005 & 2006 & 2007 & 2008 & 2009 & 2010 & 2011 & 2012 & 2013 \\
\hline Ministry of Health & 25.00 & 25.00 & 25.00 & 25.00 & 25.00 & 25.00 & 25.00 & 24.42 & 23.88 & 24.29 & 25.45 & 26.83 \\
\hline University & 22.00 & 22.00 & 22.00 & 22.00 & 22.00 & 22.00 & 22.00 & 22.07 & 20.23 & 16.52 & 15.95 & 12.27 \\
\hline Private & 12.00 & 14.00 & 18.00 & 15.00 & 14.00 & 11.00 & 8.00 & 7.67 & 8.38 & 9.24 & 8.60 & 8.30 \\
\hline All Hospitals & 22.40 & 22.80 & 23.65 & 22.75 & 22.40 & 21.25 & 19.80 & 19.39 & 19.51 & 19.67 & 20.24 & 20.82 \\
\hline
\end{tabular}

Table 10. Distribution of Hospital Visits by Type of Institution (\%). Turkey 2002-2013

\begin{tabular}{|c|c|c|c|c|c|c|c|c|c|c|c|c|}
\hline Type of institution & 2002 & 2003 & 2004 & 2005 & 2006 & 2007 & 2008 & 2009 & 2010 & 2011 & 2012 & 2013 \\
\hline Ministry of Health & 88.32 & 88.53 & 88.90 & 88.68 & 87.07 & 84.14 & 79.18 & 77.31 & 77.62 & 75.28 & 73.59 & 73.88 \\
\hline University & 7.10 & 7.49 & 7.03 & 6.19 & 5.79 & 6.03 & 6.68 & 6.56 & 6.63 & 7.23 & 7.64 & 8.08 \\
\hline Private & 4.58 & 3.98 & 4.07 & 5.13 & 7.14 & 9.83 & 14.14 & 16.13 & 15.75 & 17.48 & 18.77 & 18.04 \\
\hline All Hospitals & 100.00 & 100.00 & 100.00 & 100.00 & 100.00 & 100.00 & 100.00 & 100.00 & 100.00 & 100.00 & 100.00 & 100.00 \\
\hline
\end{tabular}

Table 11. Distribution of Emergency Department Visits by Type of Institution (\%). Turkey 2002-2013

\begin{tabular}{|c|c|c|c|c|c|c|c|c|c|c|c|c|}
\hline Type of institution & 2002 & 2003 & 2004 & 2005 & 2006 & 2007 & 2008 & 2009 & 2010 & 2011 & 2012 & 2013 \\
\hline Ministry of Health & 91.77 & 91.09 & 89.08 & 89.47 & 90.43 & 90.49 & 90.61 & 90.38 & 88.39 & 85.00 & 85.22 & 84.71 \\
\hline University & 6.63 & 5.54 & 5.00 & 3.59 & 3.13 & 2.99 & 2.83 & 2.78 & 3.32 & 3.63 & 3.87 & 3.97 \\
\hline Private & 1.60 & 3.37 & 5.92 & 6.95 & 6.44 & 6.52 & 6.56 & 6.84 & 8.29 & 11.38 & 10.91 & 11.32 \\
\hline All Hospitals & 100.00 & 100.00 & 100.00 & 100.00 & 100.00 & 100.00 & 100.00 & 100.00 & 100.00 & 100.00 & 100.00 & 100.00 \\
\hline
\end{tabular}

Table 12. Distribution of Hospital Visits by Type of Institution (\%), Istanbul 2002-2013

\begin{tabular}{|c|c|c|c|c|c|c|c|c|c|c|c|c|}
\hline Type of institution & 2002 & 2003 & 2004 & 2005 & 2006 & 2007 & 2008 & 2009 & 2010 & 2011 & 2012 & 2013 \\
\hline Ministry of Health & 74.69 & 75.05 & 77.32 & 73.48 & 72.98 & 69.17 & 64.87 & 65.01 & 67.40 & 66.10 & 66.06 & 66.16 \\
\hline University & 6.85 & 6.85 & 5.99 & 5.69 & 4.70 & 5.10 & 5.49 & 5.74 & 5.74 & 6.56 & 6.83 & 6.59 \\
\hline Private & 18.46 & 18.10 & 16.69 & 20.83 & 22.32 & 25.73 & 29.64 & 29.24 & 26.86 & 27.34 & 27.11 & 27.26 \\
\hline All Hospitals & 100.00 & 100.00 & 100.00 & 100.00 & 100.00 & 100.00 & 100.00 & 100.00 & 100.00 & 100.00 & 100.00 & 100.00 \\
\hline
\end{tabular}

Table 13. Distribution of Emergency Department Visits by Type of Institution (\%), Istanbul 2002-2013

\begin{tabular}{|c|c|c|c|c|c|c|c|c|c|c|c|c|}
\hline Type of institution & 2002 & 2003 & 2004 & 2005 & 2006 & 2007 & 2008 & 2009 & 2010 & 2011 & 2012 & 2013 \\
\hline Ministry of Health & 83.38 & 82.28 & 81.72 & 80.76 & 81.44 & 81.40 & 81.92 & 81.90 & 82.51 & 81.64 & 83.09 & 85.25 \\
\hline University & 6.73 & 6.61 & 5.57 & 5.50 & 4.61 & 5.28 & 6.10 & 6.54 & 5.95 & 5.51 & 5.38 & 3.88 \\
\hline Private & 9.89 & 11.11 & 12.70 & 13.74 & 13.95 & 13.32 & 11.98 & 11.56 & 11.54 & 12.85 & 11.53 & 10.87 \\
\hline All Hospitals & 100.00 & 100.00 & 100.00 & 100.00 & 100.00 & 100.00 & 100.00 & 100.00 & 100.00 & 100.00 & 100.00 & 100.00 \\
\hline
\end{tabular}




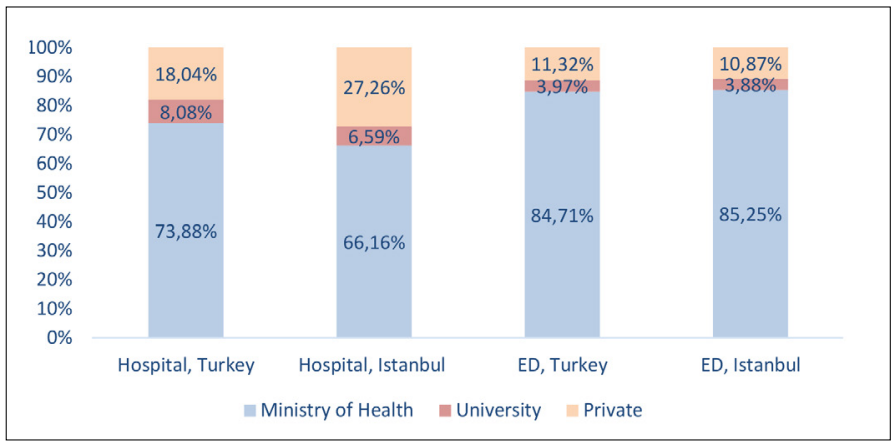

Figure 3. Distribution of Total Hospital and Emergency Department Visits by type of Institution, 2013

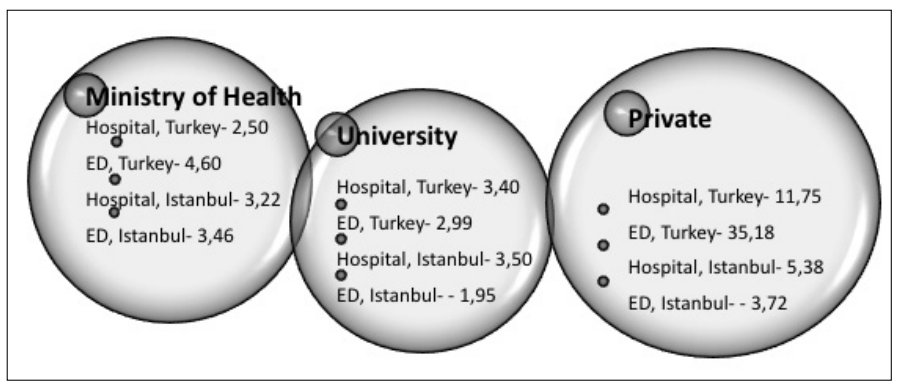

Figure 4. How many times the visits increased by between 2002 and 2013

ve the average. Kağıthane $\mathrm{PH}$ has the lowest emergency visit rate with $20.72 \%$. Easy access to the Okmeydanı TH and the hospital's comprehensive services in all medical specialties lower Kağıthane PH`s ED volume. İstinye PH has high EDV numbers because of the comprehensive medical services offered which is superior to the other hospitals in Sarıyer district. Statistically, there isn 't any significant difference in the rate of EDV between TH and secondary care hospitals (Mann-Whitney'u test $\mathrm{p}: 0.724, \mathrm{p}>0.05$ ).

The visit numbers indicates that in general distribution of total hospital visits and EDV amongst the hospitals is similar (Table 15). With total hospital visit rate of $29.6 \%$ and EDV rate of $34.16 \%$, Okmeydanı TH has the highest patient volume.

According to the data obtained from the DSS, triage rates between our hospitals vary considerably (Table 16). Although there is no requirement to triage in the ED which are registered as first level, triage is performed because of the hospital's legal obligation to collect copayment from green area patients. Generally, nearly $25 \%$ of the patients are served in the green area. There are significant differences in red and yellow areas between the hospitals because triage in ED is a relatively new practice in Turkey and triage training is still an ongoing process. Another reason is erroneous record keeping which is a widespread problem that affects all the medical information entered in HMIS.

Consequently, life-threatening cases which are intervened in the red area might get recorded as yellow. Another reason is especially in secondary care public hospitals, only the patients who are transferred to ED with an ambulance are accepted as red area patients. We see that Okmeydanı TH has a similar practice in its triage recording.

The studies conducted in the US, Australia and Europe shows that patient whose severity is triaged as red is between $10-20 \%(1-3)$. In this regard, Şişli Hamidiye Etfal TH and GOP Taksim TH can be shown as good examples both in proper triage practices and accurate record keeping.
Table 14. Number of Total Hospital Visits and Emergency Department Visits By the Hospital and rate of ED visits (\%), BKHB 2014

\begin{tabular}{|c|c|c|c|}
\hline & $\begin{array}{c}\text { Total Hospital } \\
\text { Visits }\end{array}$ & ED Visits & $\%$ \\
\hline Total & $8,050,852$ & $2,226,780$ & 27.66 \\
\hline Teaching Hospitals & $5,284,182$ & $1,496,235$ & 28.32 \\
\hline Okmeydanı & $2,382,784$ & 760,773 & 31.93 \\
\hline Şişli Hamidiye Etfal & $1,609,035$ & 422,903 & 26.28 \\
\hline GOP Taksim & $1,292,363$ & 312,559 & 24.19 \\
\hline Secondary Care Hospitals & $2,766,670$ & 730,545 & 26.41 \\
\hline Eyüp & $1,001,734$ & 255,219 & 25.48 \\
\hline İstinye & 675,544 & 215,318 & 31.87 \\
\hline Kâğıthane & 704,337 & 145,912 & 20.72 \\
\hline Sarıyer İsmail Akgün & 385,055 & 114,096 & 29.63 \\
\hline
\end{tabular}

Table 15. Distribution of Outpatient and Emergency Department visits by the Hospital (\%), BKHB 2014

\begin{tabular}{|l|c|c|c|c|}
\hline & Total \% & Total \% & EDVisits \% & EDVisits\% \\
\hline All Hospitals & 100.00 & & 100 & \\
\hline Teaching Hospitals & 65.64 & 100.00 & 67.19 & 100.00 \\
\hline Okmeydanı & 29.60 & 45.09 & 34.16 & 50.85 \\
\hline Şişli Hamidiye Etfal & 19.99 & 30.45 & 18.99 & 28.26 \\
\hline GOP Taksim & 16.05 & 24.46 & 14.04 & 20.89 \\
\hline Secondary Care Hospitals & 34.36 & 100.00 & 32.81 & 100.00 \\
\hline Eyüp & 12.44 & 36.21 & 11.46 & 34.94 \\
\hline İstinye & 8.39 & 24.42 & 9.67 & 29.47 \\
\hline Kâğıthane & 8.75 & 25.46 & 6.55 & 19.97 \\
\hline Sarıyer İsmail Akgün & 4.78 & 13.92 & 5.12 & 15.62 \\
\hline
\end{tabular}

\section{Timing of Emergency Department Visits}

When the seasonal distribution of EDV is studied, a slight increase during winter months and a slight decrease during summer months are noticed, although there is no significant difference in seasonal distribution (Table 17). Only in Kağıthane PH a dramatic decrease in EDV during summer months is observed. The same situation applies to the outpatient visits and this is because residents of the region generally spend summer months outside of Istanbul. On a monthly basis, the highest EDV volume is in January nearly in all hospitals (Table 18). February and July are noted as the months with the lowest visit rates.

Mean value of EDV monthly distribution rate in $\mathrm{TH}$ and $\mathrm{PH}$ are $8.334 \%$ and $8.333 \%$ respectively. There is no significant difference in mean values of the monthly distribution rate between $\mathrm{TH}$ and $\mathrm{PH}$. (Independent samples T test: p: 0.998, p> 0.05)

Daily patient distribution is equal in terms of total patient numbers but there is a slight increase on Mondays. Because EDV during 
weekends while the outpatient clinics are closed don't increase and it rises slightly on Mondays, we think that the patients are using the ED like the regular outpatient clinics. When the individual hospitals are analyzed, there is a significant increase in visits in Kağıthane PH and decrease in İstinye PH on weekends (Table 19).

In all hospitals, the visits are the lowest at 5:00 am. The visits are the highest in İstinye PH at 14:00, in Saryer PH at 13:00, and in others at 21:00 (Table 20). We think that insufficient specialist and outpatient clinic numbers in Sarıyer district cause the patients to visit the ED. To meet this demand, the construction of a new hospital building is underway.

When the patient volume between 05:00 am and 21:00 is compared, a significant difference is observed ("Mann-Whitney' $u$ " test: $p$ : $0.003, p<0.05)$. However, there isn't any statistically significant difference on the highest and the lowest visit hours between $\mathrm{TH}$ and $\mathrm{PH}$ (Mann-Whitney'u test for the lowest EDV hour between 05:00 am 06:00 am: p: 0.157, p>0.05. Mann-Whitney $U$ test for the highest EDV hour between 21:00-22:00: p: 0.724, p>0.05). The rapidly decreasing visit numbers after 21:00 start to increase again after 6:00 am. Increase in visits especially between 20:00 and 23:00 suggests that the number of doctors and nurses has to be increased during this time and the concept of flexible working hours is a suitable solution for ED.

EDV hourly distribution shows that the visits during working hours (8:00 am to 17:00 pm) are significantly higher in İstinye and Sarıyer PH. In Kağıthane PH visits outside of working hours are higher (Table 20). In all of our hospitals the working hour EDV rate is $47,35 \%$; outside of working hours EDV rate is $52,65 \%$ on average. This doesn't have any statistical significance (Mann-Whitney'u test: $p: 0.277$, $p>0.05$ ).

If the triage areas are assessed with their hourly distribution rates, in green area the visits are higher than other areas during working hours and the highest during lunch hours. This shows that the patients who can't get an appointment turn to ED for their general healthcare needs. In red and yellow areas the highest visit rates are at 21:00 and the lowest are at 05:00 am (Figure 5).

The green area patient rates in Sarlyer and İstinye $\mathrm{PH}$, are higher than all others, and this increases working hour visit numbers. At the same time, Kağıthane $\mathrm{PH}$ with the lowest green area visits amongst the $\mathrm{PH}$, receives $60 \%$ of its visits outside of working hours.

\section{Emergency Department Visits, Age and Gender}

When the age of patients who visit ED and the age of general population are compared (Figure 6,7 ) the first thing that comes

Table 16. Distribution of Emergency Department Visits by Triage Category (\%), BKHB 2014

\begin{tabular}{|l|c|c|c|c|c|}
\hline & Level of ED & Red & Yellow & Green & Total \\
\hline All Hospitals & & 4.48 & 71.60 & 23.92 & 100.00 \\
\hline Teaching Hospitals & & 6.57 & 71.83 & 21.60 & 100.00 \\
\hline Okmeydanı & 3. & 1.49 & 76.92 & 21.59 & 100.00 \\
\hline Şişli Hamidiye Etfal & 3. & 21.26 & 59.39 & 19.35 & 100.00 \\
\hline GOPTaksim & 2. & 9.51 & 67.41 & 23.08 & 100.00 \\
\hline Secondary Care Hospitals & & 0.46 & 71.15 & 28.39 & 100.00 \\
\hline Eyüp & 2. & 1.06 & 76.08 & 22.86 & 100.00 \\
\hline İstinye & 2. & 0.16 & 66.60 & 33.24 & 100.00 \\
\hline Kâğıthane & 1. & 0.07 & 78.06 & 21.87 & 100.00 \\
\hline Sarıyer İsmail Akgün & 1. & 0.03 & 60.96 & 39.01 & 100.00 \\
\hline
\end{tabular}

Table 17. Distribution of Emergency Department Visits by Season (\%), BKHB 2014

\begin{tabular}{|l|c|c|c|c|c|}
\hline & Spring & Summer & Fall & Winter & Total \\
\hline All Hospitals & 25.55 & 23.67 & 24.30 & 26.48 & 100.00 \\
\hline Teaching Hospitals & 25.41 & 24.04 & 24.48 & 26.07 & 100.00 \\
\hline Okmeydanı & 25.78 & 23.31 & 23.59 & 27.31 & 100.00 \\
\hline Şişli Hamidiye Etfal & 25.33 & 24.52 & 24.91 & 25.24 & 100.00 \\
\hline GOPTaksim & 24.61 & 25.18 & 26.06 & 24.15 & 100.00 \\
\hline Secondary Care Hospitals & 25.83 & 22.92 & 23.93 & 27.31 & 100.00 \\
\hline Eyüp & 26.44 & 23.50 & 22.40 & 27.67 & 100.00 \\
\hline İstinye & 25.94 & 23.56 & 23.81 & 26.69 & 100.00 \\
\hline Kâğıthane & 24.27 & 20.17 & 26.85 & 28.71 & 100.00 \\
\hline Sarıyer İsmail Akgün & 26.28 & 23.93 & 23.88 & 25.91 & 100.00 \\
\hline
\end{tabular}

Table 18. Distribution of Emergency Department Visits by Month (\%), BKHB 2014

\begin{tabular}{|c|c|c|c|c|c|c|c|c|c|c|c|c|c|}
\hline & Jan & Feb & Mar & Apr & May & Jun & July & Aug & Sep & Oct & Nov & Dec & Total \\
\hline All Hospitals & 10.33 & 7.34 & 8.58 & 8.41 & 8.56 & 8.16 & 7.32 & 8.2 & 7.93 & 8.38 & 7.99 & 8.8 & 100.00 \\
\hline Teaching Hospitals & 10.07 & 7.33 & 8.43 & 8.40 & 8.59 & 8.34 & 7.44 & 8.26 & 8.00 & 8.41 & 8.07 & 8.67 & 100.00 \\
\hline Şişli Hamidiye Etfal & 10.13 & 7.12 & 8.32 & 8.46 & 8.54 & 8.30 & 7.60 & 8.62 & 8.15 & 8.84 & 7.91 & 7.98 & 100.00 \\
\hline GOPTaksim & 8.17 & 6.75 & 8.02 & 8.09 & 8.51 & 8.56 & 7.76 & 8.86 & 8.70 & 8.83 & 8.53 & 9.23 & 100.00 \\
\hline Eyüp & 11.56 & 7.54 & 8.85 & 8.56 & 9.03 & 8.36 & 7.07 & 8.06 & 7.52 & 7.77 & 7.11 & 8.56 & 100.00 \\
\hline İstinye & 10.24 & 7.50 & 9.12 & 8.48 & 8.34 & 7.94 & 7.36 & 8.27 & 7.78 & 8.34 & 7.69 & 8.94 & 100.00 \\
\hline Kâğıthane & 10.82 & 7.01 & 8.49 & 8.03 & 7.75 & 6.30 & 6.53 & 7.34 & 8.14 & 9.19 & 9.52 & 10.88 & 100.00 \\
\hline Sarıyer İsmail Akgün & 10.47 & 7.27 & 9.09 & 8.63 & 8.56 & 8.10 & 7.20 & 8.63 & 7.97 & 8.36 & 7.55 & 8.16 & 100.00 \\
\hline
\end{tabular}


Table 19. Distribution of Emergency Department Visits by Day (\%), BKHB 2014

\begin{tabular}{|l|c|c|c|c|c|c|c|c|c|c|}
\hline & Monday & Tuesday & Wednesday & Thursday & Friday & Weekday & Saturday & Sunday & Weekend & Total \\
\hline All Hospitals & 15.11 & 14.04 & 14.28 & 13.89 & 14.05 & 71.37 & 14.27 & 14.36 & 28.63 & 100.00 \\
\hline Teaching Hospitals & 15.20 & 14.01 & 14.27 & 13.76 & 13.91 & 71.15 & 14.23 & 14.62 & 28.85 & 100.00 \\
\hline Okmeydanı & 15.45 & 13.99 & 14.28 & 13.82 & 14.03 & 71.57 & 13.99 & 14.44 & 28.43 & 100.00 \\
\hline Şişli Hamidiye Etfal & 14.94 & 13.89 & 14.22 & 13.60 & 13.79 & 70.44 & 14.56 & 15.00 & 29.56 & 100.00 \\
\hline GOP Taksim & 14.95 & 14.22 & 14.30 & 13.81 & 13.78 & 71.06 & 14.36 & 14.57 & 28.93 & 100.00 \\
\hline Secondary Care Hospitals & 14.92 & 14.09 & 14.31 & 14.17 & 14.34 & 71.83 & 14.34 & 13.83 & 28.17 & 100.00 \\
\hline Eyüp & 14.69 & 14.03 & 14.02 & 13.82 & 14.09 & 70.65 & 14.30 & 15.05 & 29.35 & 100.00 \\
\hline İstinye & 16.29 & 14.83 & 15.38 & 15.20 & 15.44 & 77.14 & 11.69 & 11.17 & 22.86 & 100.00 \\
\hline Kâğınthane & 13.24 & 13.10 & 13.10 & 13.33 & 13.35 & 66.12 & 17.77 & 16.12 & 33.89 & 100.00 \\
\hline Sarıyer İsmail Akgün & 14.99 & 14.08 & 14.47 & 14.11 & 14.08 & 71.73 & 15.07 & 13.21 & 28.28 & 100.00 \\
\hline
\end{tabular}

Table 20. Distribution of Emergency Department Visits by Hour (\%), BKHB 2014

\begin{tabular}{|c|c|c|c|c|c|c|c|c|c|c|c|c|c|c|c|c|c|c|c|c|c|c|c|c|c|c|}
\hline & 8 & 9 & 10 & 11 & 12 & 13 & 14 & 15 & 16 & WH & 17 & 18 & 19 & 20 & 21 & 22 & 23 & 24 & 1 & 2 & 3 & 4 & 5 & 6 & 7 & OWH \\
\hline All Hospitals & 3.26 & 5.02 & 5.57 & 5.64 & 5.01 & 5.92 & 6.30 & 5.59 & 5.04 & 47.35 & 4.66 & 4.86 & 5.79 & 6.60 & 6.92 & 6.23 & 4.89 & 3.57 & 2.19 & 1.44 & 1.13 & 0.92 & 0.80 & 0.96 & 1.69 & 52.65 \\
\hline Teaching Hospitals & 2.94 & 4.59 & 5.33 & 5.50 & 5.03 & 5.79 & 6.21 & 5.53 & 4.97 & 45.90 & 4.63 & 4.79 & 5.76 & 6.62 & 6.99 & 6.43 & 5.14 & 3.81 & 2.39 & 1.60 & 1.26 & 1.05 & 0.89 & 1.03 & 1.70 & 54.09 \\
\hline Okmeydanı & 3.13 & 4.86 & 5.54 & 5.56 & 5.16 & 5.95 & 6.43 & 5.67 & 5.02 & 47.32 & 4.62 & 4.80 & 5.91 & 6.71 & 7.07 & 6.32 & 4.76 & 3.60 & 2.14 & 1.39 & 1.03 & 0.85 & 0.78 & 0.95 & 1.75 & 52.68 \\
\hline Şişli Hamidiye Etfal & 2.81 & 4.35 & 5.13 & 5.31 & 4.91 & 5.62 & 5.99 & 5.46 & 5.14 & 44.72 & 4.82 & 4.75 & 5.35 & 6.15 & 6.50 & 6.09 & 5.09 & 4.16 & 2.98 & 2.08 & 1.70 & 1.43 & 1.14 & 1.23 & 1.80 & 55.27 \\
\hline GOPTaksim & 2.89 & 4.57 & 5.33 & 5.62 & 5.03 & 5.80 & 6.21 & 5.46 & 4.76 & 45.67 & 4.46 & 4.82 & 6.01 & 7.00 & 7.41 & 6.88 & 5.57 & 3.67 & 2.05 & 1.34 & 1.04 & 0.87 & 0.75 & 0.90 & 1.55 & 54.32 \\
\hline Secondary Care Hospitals & 3.74 & 5.43 & 5.66 & 5.70 & 4.82 & 5.85 & 6.19 & 5.50 & 5.20 & 48.09 & 4.75 & 4.93 & 5.82 & 6.62 & 6.96 & 6.21 & 4.95 & 3.40 & 1.97 & 1.27 & $\mid 1.01$ & 0.76 & 0.70 & 0.90 & 1.67 & 51.91 \\
\hline Eyüp & 3.26 & 5.16 & 5.28 & 5.35 & 4.76 & 5.61 & 6.03 & 5.21 & 4.70 & 45.36 & 4.51 & 5.01 & 6.26 & 7.43 & 7.71 & 6.57 & 5.02 & 3.48 & 2.05 & 1.30 & 1.06 & 0.81 & 0.73 & 0.98 & 1.71 & 54.63 \\
\hline İstinye & 5.09 & 7.23 & 7.39 & 7.15 & 4.96 & 7.18 & 7.73 & 6.54 & 4.68 & 57.95 & 4.03 & 4.33 & 5.00 & 5.59 & 5.80 & 4.98 & 3.65 & 2.42 & 1.43 & 0.93 & 0.75 & 0.56 & 0.51 & 0.62 & 1.47 & 42.07 \\
\hline Kâğıthane & 2.88 & 3.89 & 4.32 & 4.60 & 4.75 & 4.75 & 4.80 & 4.75 & 6.23 & 40.97 & 5.72 & 5.44 & 6.19 & 6.83 & 7.38 & 7.07 & 6.18 & 4.31 & 2.42 & 1.59 & 1.21 & 0.92 & 0.86 & 1.10 & 1.82 & 59.04 \\
\hline Sarıyer İsmail Akgün & 3.90 & 6.72 & 6.84 & 6.53 & 5.26 & 6.94 & 6.72 & 6.01 & 5.57 & 54.49 & 5.12 & 5.62 & 6.00 & 6.09 & 5.98 & 4.95 & 3.61 & 2.45 & 1.37 & 0.82 & 0.61 & 0.44 & 0.41 & 0.64 & 1.41 & 45.52 \\
\hline Red & 2.78 & 4.17 & 5.14 & 5.34 & 5.01 & 5.81 & 6.13 & 5.58 & 5.15 & 45.11 & 4.65 & 4.62 & 5.34 & 6.27 & 6.52 & 6.16 & 5.10 & 4.18 & 2.88 & 2.12 & 1.65 & 1.35 & 1.16 & 1.22 & 1.67 & 54.89 \\
\hline Yellow & 3.27 & 4.91 & 5.39 & 5.45 & 4.97 & 5.66 & 6.03 & 5.41 & 4.94 & 46.03 & 4.60 & 4.82 & 5.82 & 6.72 & 7.11 & 6.45 & 5.12 & 3.75 & 2.29 & 1.49 & 1.17 & 0.94 & 0.84 & 1.03 & 1.82 & 53.97 \\
\hline Green & 3.50 & 5.47 & 6.06 & 6.06 & 5.13 & 6.67 & 7.08 & 6.01 & 5.21 & 51.19 & 4.78 & 5.01 & 6.01 & 6.64 & 6.81 & 5.81 & 4.38 & 3.04 & 1.57 & 1.00 & 0.72 & 0.58 & 0.51 & 0.64 & 1.31 & 48.81 \\
\hline
\end{tabular}

to attention is that the rate of patient within 5-9 and 10-14 years groups are lower than the proportion they represent in the general population. The $0-4$ years group has the highest visit (11.39\%) and represents $8.1 \%$ of the population. Apart from these exceptions age distribution of the patients and the population does not show a big difference.

The patients between the ages of 25 and 44 are the biggest patient group with $34.35 \%$ of visits (Table 21 ). If we look at the data from the US or Australia, the 25-44 years group has the highest visit volume as well. Generally in these two countries patient visits under the age of 45 are lower than the BKHB hospitals, especially the 65+ patient visits are significantly higher. This situation might be explained with their population structure. According to the World Bank data the $65+$ years group is $14.9 \%$ in the US and Australia, while it is $7.69 \%$ in Turkey. In summary, age and gender distribution of the patient population who visit ED is in line with the country's general age and gender distribution with a few exceptions.

If we consider all the patients who visit ED, the distribution between male and female patients is nearly equal. Until the ages of 35 to 39 , male patients dominate but in $35+$ years, females have a hi-

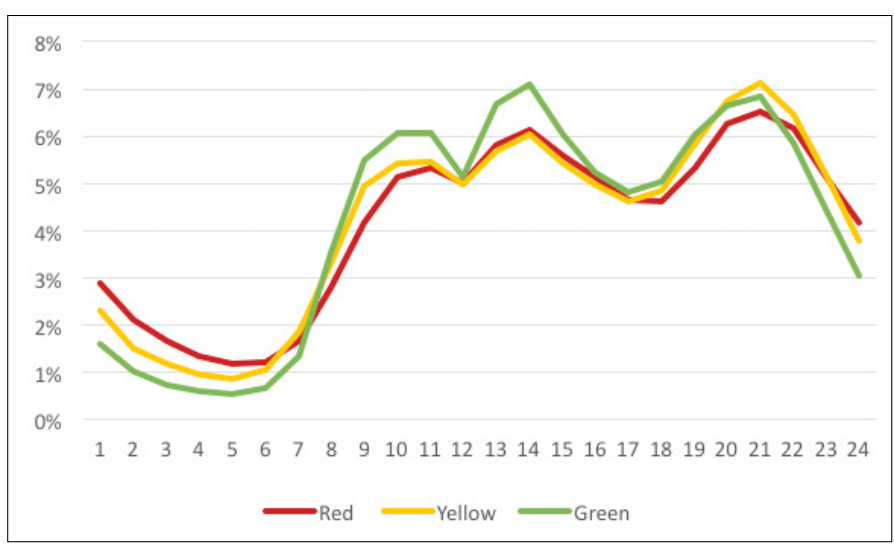

Figure 5. Distribution of Emergency Department hourly visit rate based on triage category, BKHB 2014

gher visit rate. Especially in under 15 years group male patients have higher visit rates than females; $26.15 \%$ of males are under 15 while the same figure is $20.78 \%$ for females (Table 22 ). 
The patients who are between the ages of 1 to 14 have the highest rate on red area visits (Table 23). In all visits the rate of 1-14 years group is $21.87 \%$ but within the red area the rate is $31.21 \%$. Again, the $65+$ patient rate is higher than the other age groups in red area. Female patients have a $51.4 \%$ red area visit rate. But in red area visits for ages under 15, male patient rate is higher than the females.

In green and yellow areas patients between the ages of 25 and 44 has the highest visit rate regardless of gender. Again, male patients under the age of 15 have a higher rate than the females. Another feature is that the $65+$ years patient rate has a lower value in green area than in red and yellow areas.

\section{EMERGENCY DEPARTMENT CAPACITY}

The capacity and the quality of our hospital services depend on the adequacy of the equipment and human resources. In an ED; doctor, nurse and bed numbers are the most important resources affecting number of patients that can be properly treated. There isn't any planned appointment in ED therefore no matter how high the patient volume, the care has to be delivered with the available resources. Because of the lack of sufficient number of healthcare staff and equipment, the waiting times might be higher and the record

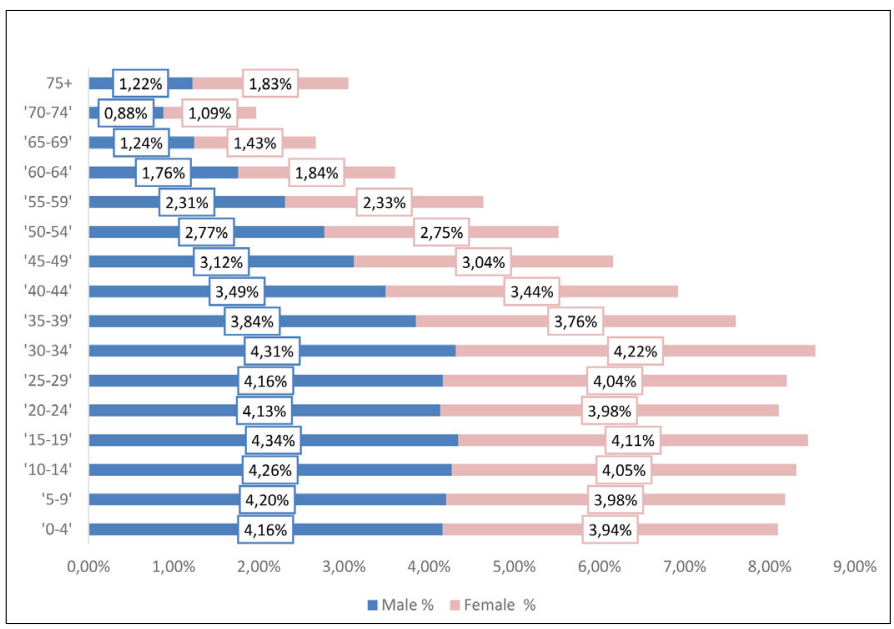

Figure 6. Distribution of Population by Age and Gender, Turkey 2013

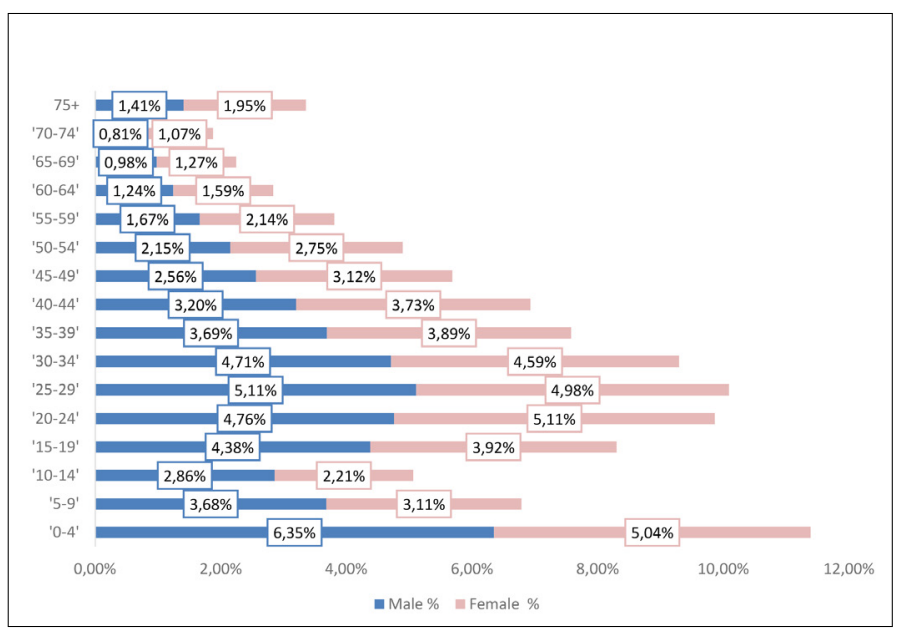

Figure 7. Distribution of Emergency Department Visits by Age and Gender, BKHB 2014 keeping might be compromised. Moreover because of the limited patient time, doctors and nurses might not properly deliver the necessary care. Therefore it is extremely important that there are enough resources to meet the service demand in ED.

Table 24, 25 and 26 show patient volumes per doctor, nurse and bed and the average time allocated to each patient daily in our ED. If we assume maximum of an hour break time within 8 work hours, a doctor can allocate 8 minutes to each patient on average and a nurse can spend 13 minutes on each patient. But in ED, the visit volume is fluctuating dramatically depending on the time of the day and the triage area. The size of workforce also changes depending on the triage area and the time of the day. Therefore it is important to emphasize that the patient time for a doctor or a nurse depends on the ED overcrowding, triage area and the visit time. The numbers in related tables are average values and give a general idea about the time that can be spared for a patient.

There might be shortenings or prolongation in bed turnover time observed in Table26 because of the same reasons. But generally, the total length of stay in emergency depending on the triage area shown in Table 27 and average bed turnover rates shown in Table 26 are coherent. But the vast difference between length of stay in Şişli Hamidiye Etfal TH (red area 91 minutes, yellow area 187 minutes, green area 169 minutes) and bed turnover rate (76 minutes) suggests that the bed capacity has to be increased in this hospital

If we examine the relation between daily EDV numbers and the number of doctors, nurses and beds, the correlation factor $(r)$ 's significance value $(p)$ is 0.000 for the doctors; 0.003 for the nurses and 0.001 for the beds with $p<0.05$. Therefore the daily EDV numbers and the number of doctors, nurses, and beds are strongly correlated. According to the "Pearson Correlation" $r$ value there is a strong relation of $97.3 \%$ between daily EDV and the number of doctors, $92.72 \%$ between daily EDV and the number of nurses, $95.3 \%$ between daily EDV and number of beds.

\section{QUALITY MEASUREMENT INEMERGENCY DEPARTMENT}

The concept of quality can be summarized as the capacity of the product or service to meet customer expectations but it has different criteria and measurement methods for each sector. Defining and measuring quality of healthcare is quite difficult. You produce service for people who entrust you with their lives and standardization of services aren 't always possible.

Thanks to the Healthcare Transformation Program, reforms regarding quality in healthcare gained momentum for the past 10 years.

Table 21. International Comparison of Emergency Department Visits by Age (\%)

\begin{tabular}{|l|c|c|c|}
\hline & BKHB & USA(2) & Australia(3) \\
\hline Total & 100.00 & 100.00 & 100.00 \\
\hline Under 15 Years & 23.45 & 18.20 & 21.66 \\
\hline 15-24 Years & 17.64 & 16.30 & 15.14 \\
\hline 25-44 Years & 34.35 & 28.70 & 25.48 \\
\hline 45-64 Years & 17.19 & 21.90 & 18.91 \\
\hline 65 Years and Over & 7.37 & 14.90 & 18.81 \\
\hline
\end{tabular}


Table 22. Number and Distribution of Emergency Department Visits by Age And Gender (\%), BKHB 2014

\begin{tabular}{|c|c|c|c|}
\hline & Number of Visits & \multicolumn{2}{|c|}{$\%$} \\
\hline Total & $2,226,780$ & \multicolumn{2}{|l|}{100.00} \\
\hline Female & $1,118,634$ & \multicolumn{2}{|l|}{50.24} \\
\hline Male & $1,108,146$ & \multicolumn{2}{|l|}{49.76} \\
\hline Under 15 Years & 522,269 & 23.45 & 100.00 \\
\hline Under 1 Year & 35,323 & 1.59 & 6.76 \\
\hline 1-4 Years & 212,847 & 9.56 & 40.75 \\
\hline 5-14 Years & 274,099 & 12.31 & 52.48 \\
\hline 15-24 Years & 392,792 & \multicolumn{2}{|l|}{17.64} \\
\hline 25-44 Years & 764,919 & \multicolumn{2}{|l|}{34.35} \\
\hline 45-64 Years & 382,791 & \multicolumn{2}{|l|}{17.19} \\
\hline 65 Years and Over & 164,009 & 7.37 & 100.00 \\
\hline $65-74$ Years & 91,779 & 4.12 & 55.96 \\
\hline 75 Years and Over & 72,230 & 3.24 & 44.04 \\
\hline \multicolumn{4}{|l|}{ Gender and Age } \\
\hline Female & $1,118,634$ & \multicolumn{2}{|l|}{100.00} \\
\hline Under 15 Years & 232,483 & 20.78 & 100.00 \\
\hline Under 1 Year & 15,795 & 1.41 & 6.79 \\
\hline 1-4 Years & 93,686 & 8.38 & 40.30 \\
\hline 5-14 Years & 123,002 & 11.00 & 52.91 \\
\hline 15-24 Years & 194,079 & \multicolumn{2}{|l|}{17.35} \\
\hline 25-44 Years & 386,476 & \multicolumn{2}{|l|}{34.55} \\
\hline 45-64 Years & 212,551 & \multicolumn{2}{|l|}{19.00} \\
\hline 65 Years and Over & 93,045 & 8.32 & 100.00 \\
\hline 65-74 Years & 51,653 & 4.62 & 55.51 \\
\hline 75 Years and Over & 41,392 & 3.70 & 44.49 \\
\hline Male & $1,108,146$ & \multicolumn{2}{|l|}{100.00} \\
\hline Under 15 Years & 289,786 & 26.15 & 100.00 \\
\hline Under 1 Year & 19,528 & 1.76 & 6.74 \\
\hline 1-4 Years & 119,161 & 10.75 & 41.12 \\
\hline 5-14 Years & 151,097 & 13.64 & 52.14 \\
\hline 15-24 Years & 198,713 & \multicolumn{2}{|l|}{17.93} \\
\hline 25-44 Years & 378,443 & \multicolumn{2}{|l|}{34.15} \\
\hline 45-64 Years & 170,240 & \multicolumn{2}{|l|}{15.36} \\
\hline 65 Years and Over & 70,964 & 6.40 & 100.00 \\
\hline $65-74$ Years & 40,126 & 3.62 & 56.54 \\
\hline 75 Years and Over & 30,838 & 2.78 & 43.46 \\
\hline
\end{tabular}

Currently, the legislation on quality of healthcare which is updated on $06 / 08 / 2013$ is in force and it regulates principles and procedures of healthcare quality standards based on patient safety, employee safety, patient satisfaction and employee satisfaction and the implementation of these standards. The legislation applies to all public and private healt-
Table 23. Distribution of Emergency Department Visits by Age and Gender for each Triage Category (\%), BKHB 2014

\begin{tabular}{|c|c|c|c|}
\hline & Red & Yellow & Green \\
\hline Total & 100.00 & 100.00 & 100.00 \\
\hline Female & 51.40 & 50.74 & 49.96 \\
\hline Male & 48.60 & 49.26 & 50.04 \\
\hline Under 15 Years & 32.28 & 23.85 & 24.51 \\
\hline Under 1 Year & 1.07 & 1.32 & 1.38 \\
\hline 1-4 Years & 14.98 & 9.79 & 9.94 \\
\hline 5-14 Years & 16.23 & 12.74 & 13.19 \\
\hline 15-24 Years & 13.76 & 17.05 & 19.20 \\
\hline 25-44 Years & 26.95 & 33.77 & 35.70 \\
\hline 45-64 Years & 14.55 & 17.56 & 15.76 \\
\hline 65 Years and Over & 12.46 & 7.77 & 4.82 \\
\hline $65-74$ Years & 5.51 & 4.38 & 2.96 \\
\hline 75 Years and Over & 6.95 & 3.40 & 1.86 \\
\hline \multicolumn{4}{|l|}{ Gender and Age } \\
\hline Female & 100.00 & 100.00 & 100.00 \\
\hline Under 15 Years & 28.19 & 20.72 & 22.58 \\
\hline Under 1 Year & 0.93 & 1.16 & 1.25 \\
\hline 1-4 Years & 13.08 & 8.36 & 9.05 \\
\hline 5-14 Years & 14.17 & 11.19 & 12.28 \\
\hline $15-24$ Years & 14.90 & 16.90 & 18.88 \\
\hline 25-44 Years & 29.67 & 34.34 & 35.33 \\
\hline 45-64 Years & 14.07 & 19.34 & 17.77 \\
\hline 65 Years and Over & 13.17 & 8.70 & 5.44 \\
\hline $65-74$ Years & 5.39 & 4.87 & 3.33 \\
\hline 75 Years and Over & 7.78 & 3.83 & 2.11 \\
\hline Male & 100.00 & 100.00 & 100.00 \\
\hline Under 15 Years & 36.61 & 27.08 & 26.45 \\
\hline Under 1 Year & 1.22 & 1.48 & 1.51 \\
\hline 1-4 Years & 16.99 & 11.26 & 10.83 \\
\hline 5-14 Years & 18.39 & 14.34 & 14.10 \\
\hline $15-24$ Years & 12.56 & 17.21 & 19.52 \\
\hline 25-44 Years & 24.07 & 33.17 & 36.07 \\
\hline 45-64 Years & 15.06 & 15.73 & 13.76 \\
\hline 65 Years and Over & 11.71 & 6.81 & 4.21 \\
\hline $65-74$ Years & 5.64 & 3.86 & 2.59 \\
\hline 75 Years and Over & 6.07 & 2.95 & 1.61 \\
\hline
\end{tabular}

hcare institutions serving in the diagnosis, treatment and rehabilitation and preventive healthcare areas. The current Healthcare Services Quality Standards might be obtained from the website of Department of Quality and Accreditation in Healthcare. Almost all standards are focused on the structural qualification and adequacy of equipment in ED and there are li- 
Table 24. Average Amount of Time a Doctor can Spend per Emergency Department visit, BKHB 2014

\begin{tabular}{|l|c|c|c|c|}
\hline & $\begin{array}{c}\text { Number of } \\
\text { Daily ED } \\
\text { Visits (A) }\end{array}$ & $\begin{array}{c}\text { Number } \\
\text { of Doctors } \\
\text { (B) }\end{array}$ & A/B & $\begin{array}{c}\text { Patient } \\
\text { Time/ } \\
\text { Min }\end{array}$ \\
\hline Total & 6,101 & 40.83 & 149 & 8 \\
\hline Teaching Hospitals & 4,099 & 30.33 & 135 & 9 \\
\hline Okmeydanı & 2,084 & 16.00 & 130 & 10 \\
\hline Şişli Hamidiye Etfal & 1,159 & 10.33 & 112 & 11 \\
\hline GOPTaksim & 856 & 4.00 & 214 & 6 \\
\hline Secondary Care Hospitals & 2,001 & 10.50 & 191 & 7 \\
\hline Eyüp & 699 & 3.50 & 200 & 6 \\
\hline İstinye & 590 & 3.00 & 197 & 6 \\
\hline Kâğıthane & 400 & 2.00 & 200 & 6 \\
\hline Sarıyer İsmail Akgün & 313 & 2.00 & 156 & 8 \\
\hline *A: Number of daily ED visits is calculated by dividing total number of ED visits by 365. \\
* Patient time 21x60/(A/B)
\end{tabular}

Table 25. Average Amount of Time a Nurse can Spend per Emergency Department visit, BKHB 2014

\begin{tabular}{|l|c|c|c|c|}
\hline & $\begin{array}{c}\text { Number } \\
\text { of Daily ED } \\
\text { Visits (A) }\end{array}$ & $\begin{array}{c}\text { Number } \\
\text { of Nurses } \\
\text { (C) }\end{array}$ & A/C & $\begin{array}{c}\text { Patient } \\
\text { Time } \\
\text { /Min }\end{array}$ \\
\hline Total & 6,101 & 64 & 95 & 13 \\
\hline Teaching Hospitals & 4,099 & 47 & 87 & 14 \\
\hline Okmeydanı & 2,084 & 20 & 104 & 12 \\
\hline Şişli Hamidiye Etfal & 1,159 & 18 & 64 & 20 \\
\hline GOPTaksim & 856 & 9 & 95 & 13 \\
\hline Secondary Care Hospitals & 2,001 & 17 & 118 & 11 \\
\hline Eyüp & 699 & 6 & 117 & 11 \\
\hline İstinye & 590 & 5 & 118 & 11 \\
\hline Kâğıthane & 400 & 4 & 100 & 13 \\
\hline Sarıyer İsmail Akgün & 313 & 2 & 156 & 8 \\
\hline *Patient time 21x60/(A/C) & & & & \\
\hline
\end{tabular}

mited clinical quality criteria to evaluate results of healthcare delivery methods. Therefore criteria should be developed for the healthcare service providers to evaluate clinical quality without being limited to existing laws and systems should be designed to easily monitor these standards.

National Healthcare System (NHS) of UK defines quality in healthcare as "doing the right thing first time, every time". In this aspect quality healthcare services might be evaluated in 6 dimensions:

- Safe: Avoiding interventions which might harm the patient,

- $\quad$ Effective: Giving the right services to the right people, avoiding treatments and procedures which won't benefit the patient,

- Patient centered: Giving priority to the needs, preferences and values of the patient,

- Timely: Shortening waiting times for the people who deliver and who receive healthcare,
Table 26. Number of Patients per Emergency Department Bed, BKHB 2014

\begin{tabular}{|l|c|c|c|c|}
\hline & $\begin{array}{c}\text { Number } \\
\text { of Daily ED } \\
\text { Visits (A) }\end{array}$ & $\begin{array}{c}\text { Number } \\
\text { of Beds } \\
\text { (D) }\end{array}$ & A/D & $\begin{array}{c}\text { Bed } \\
\text { Turnover } \\
\text { Time / Min }\end{array}$ \\
\hline Total & 6,101 & 243 & 25 & 57 \\
\hline Teaching Hospitals & 4,099 & 170 & 24 & 60 \\
\hline Okmeydanı & 2,084 & 76 & 27 & 53 \\
\hline Şişli Hamidiye Etfal & 1,159 & 61 & 19 & 76 \\
\hline GOP Taksim & 856 & 33 & 26 & 55 \\
\hline Secondary Care Hospitals & 2,001 & 73 & 27 & 53 \\
\hline Eyüp & 699 & 25 & 28 & 51 \\
\hline İstinye & 590 & 22 & 27 & 54 \\
\hline Kâğıthane & 400 & 20 & 20 & 72 \\
\hline Sarıyer İsmail Akgün & 313 & 6 & 52 & 28 \\
\hline * Bed turnover time 24x60/ (A/D) & & & \\
\hline
\end{tabular}

Table 27. Length of Stay in the Emergency Departments for each Triage Category (Minute), BKHB 2014

\begin{tabular}{|l|c|c|c|}
\hline & Red & Yellow & Green \\
\hline All Hospitals & 89 & 73 & 62 \\
\hline Teaching Hospitals & 84 & 109 & 96 \\
\hline Okmeydanı & 99 & 69 & 57 \\
\hline Şişli Hamidiye Etfal & 91 & 187 & 169 \\
\hline GOP Taksim & 61 & 72 & 61 \\
\hline Secondary Care Hospitals & 94 & 38 & 27 \\
\hline Eyüp & 29 & 27 & 28 \\
\hline İstinye & 191 & 63 & 41 \\
\hline Kâğıthane & 143 & 34 & 23 \\
\hline Sarıer İsmail Akgün & 14 & 27 & 16 \\
\hline
\end{tabular}

- Efficient: Reduction of waste,

- Equitable: Serve everyone equally.

For emergency healthcare, timeliness and effectiveness are the most important components of quality. To measure the timeliness of care delivery, detailed data which follow the patient's ED journey is needed. In BKHB we continue with the development of detailed monitoring systems in our hospitals and currently we can observe timeliness of healthcare service ability from the patient's total length of stay.

In our hospitals patient's average length of stay in ED is between 1 and 1.5 hours, depending on the triage area. Şişli Hamidiye Etfal TH has the longest yellow area waiting time with 3 hours (Table 27). Average length of stay in the US and Australia is nearly 4 hours $(2,3)$. One reason that explains the short waiting time in our hospitals might be that the patients choose ED for their simple medical problems. Although our waiting time is short which shows our patients get served on time, we need to question whether we can spend enough time with each patient and make accurate diagnosis and treatment possible within this short time. 
Red area average length of stay is 89 minutes (TH: 84 and PH: 94 minutes). İstinye PH and Kağıthane PH with their 191 and 143 minutes respectively, affect the $\mathrm{PH}$ average values significantly (Table 27). Average length of stay in the yellow area is 68 minutes (TH: 109 and $\mathrm{PH}: 38$ minutes). Şişli Hamidiye Etfal has the longest average length of stay in yellow area within the TH with 187 minutes (Table 27). The average length of stay in green area is 56 minutes (TH: 96 and PH: 27 minutes). Şişli Hamidiye Etfal has the longest average length of stay among TH in the green area with 169 minutes (Table 27).

A good way to measure the effectiveness of care in ED is to track readmissions. A rise in the readmission of the same patient with the same complaints shows that you are not delivering the care effectively and your diagnosis and/or treatment is insufficient. We in BKHB follow the readmission rates to measure the ED quality using our DSS. Another parameter that we can measure the effectiveness of ED is the frequent visits. Frequent visits shows not only the service effectiveness but also is an indicator of the service being delivered in the right place or not. So it can be accepted also as an efficiency criterion. Instead of visiting an outpatient clinic or family physician, a patient's inappropriate and frequent visit to ED is a waste of resources and the patient will not find the proper cure. Frequent visits to the ED which is widely discussed and investigated internationally is measured in BKHB for the first time in Turkey and the results are published in our survey. Analysis is hospital-based and involves 2,212,910 visits of $1,234,228$ patients. Data regarding the frequent visits can be seen in Table 28, 29 and 30.

Although not an internationally accepted standard, 5 or more EDV of the same patient in a year is accepted as a frequent visit. The reasons for frequent ED visits are plenty. Some of the chief reasons are people's habits of using ED for simple healthcare problems, ED care being free of charge, acute exacerbations of chronic diseases, behavioral disorders and mental illnesses, alcohol and substance addiction $(4,5)$. Analyzing the data of patients who frequently visit ED of $B K H B$, we determine that the majority of these patients see ED as the first place to go for general healthcare problems.

Rate of 5 or more visits to ED in our hospitals were 19\% in 2013 and $23 \%$ in 2014 . We did not find any previous study on the frequent ED visits in Turkey. In international literature there are many studies on this subject and the frequent emergency visit numbers can be seen below. If we compare BKHB `s numbers with other countries, the frequent visit rate in our country is similar to the US and Canada, which have strong secondary and tertiary care system but weak in primary care unlike European counterparts.

- $\quad$ Netherlands: 7 or more $3.3 \%$ (6)

- $\quad$ UK: 10 or more $1.9 \%$ (7)

- $\quad$ Switzerland: 12 or more $0.8 \%(8)$

- Taiwan: 4 or more $14.3 \%$ (9)

- Australia: 5 or more $2.4 \%(10)$

- Canada: 5 or more $22.5 \%$ (11)

- US: 5 or more $17.6(12)$

As shown in Figure 8, patient who visit ED only once a year constitute $65.78 \%$ of the patients but $36.39 \%$ of total ED visits. This means $2 / 3$ of patients make up for $1 / 3$ of ED patient load. Patients who present to the ED 5-9 times in a year are a small group with $4.68 \%$ but make up $16.07 \%$ of the EDV (Table 28, 29).

İstinye $\mathrm{PH}$ and Sarlyer İsmail Akgün PH has the highest rate of 5 or more visits with $30.88 \%$ and $29.36 \%$ respectively (Figure 9 ). In
Şişli Hamidiye Etfal TH the frequent visits are the lowest with 15.36\%. Similarly, Eyüp and Kağıthane PH frequent visit rates are between 15$16 \% .5 .7 \%$ of our patients who visit the ED $(\sigma+-\% 2.10, \min 3.49 \%$ and max $8.38 \%$ ) belongs to the patient group who visit 5 or more times. This patient group makes up $22.9 \%$ of total emergency service load ( $\sigma+-7 \% \min 15.36 \%$ and $\max 30.88 \%$ ).

There is no significant difference of frequent visits of 5 or more times between $\mathrm{TH}$ and secondary care hospitals (Mann Whitney'u test p: 0.480 and $p>0.05$ ). $57.4 \%$ of patients who visit 20 or more times consist of male patients. Other than the patients who visit 20 or more times, gender distribution is slightly in favor of female patients (Table 30). In line with the general visit distribution the age group of 25-44 and under 15 years constitute most of the visits. Male patient rate that is 65 years or above is especially high in 20 or more visits subgroup. The same rate is limited to $14 \%$ for females.

The rate of patients who don 't get better or who get worse after their first visit and get readmitted in 72 hours with the same complaint is an important indicator of healthcare quality. Although not an internationally accepted rule, lower than $1 \%$ is considered as an acceptable figure (13). Readmision within 24 hours is one of the standard quality indicators to be monitored in Turkey. Readmissions over a certain level should be considered as an indicator of the ED not functioning properly and the reasons should be investigated.

Rates of patients with readmissions in 24 and 72 hours are seen in Table 31. In general 156 of each 10,000 patient make another EDV within 24 hours of their first appearance. For 72 hours the number is 362. İstinye PH has the lowest rate of readmission in 24 hours, although its readmission rate in 72 hours is the highest with $5.7 \%$. This might be caused by the erroneous recording of patient who actually needs an injection or wound care with the SUT (Health Application Communiqué) submission code of "Emergency Examination". There isn 't any significant difference between $\mathrm{TH}$ and $\mathrm{PH}$ in terms of readmissions in 24 hours (Mann Whitney'u test: p: 0.297 and p>0.05).

\section{DIAGNOSIS PATTERN OF EMERGENCY DEPARTMENT VISITS}

As pointed out in the section where we assess the ED resources, all personnel working in ED, especially doctors and nurses have heavy workload. Doctors who have a hard time allocating enough time to patients unfortunately cannot always record patient medical information to HMIS properly. Medical information recording is usually done by data entry clerks and the end result is wrong diagnosis coding. Due to these reasons, incorrect or incomplete patient diagnoses and treatment data might be entered into the information systems.

Our survey consists of diagnosis data taken from HMIS and based on ICD 10 codes. No comparisons with patient paper files have been made. There is not $100 \%$ reliability on diagnosis data but because of the very high patient volumes we think we can ignore the loss of data caused by incomplete or incorrect data entries.

2,233,905 diagnoses were made for 2,226,780 visits including multiple diagnoses. When evaluated according to major disease categories, number one diagnosis group is "R00-R99 Symptoms, signs and abnormal clinical and laboratory findings, not elsewhere classified" (30,36\%), and the number two is "J00-J99 Diseases of the respiratory system" (29,87\%). However, if we make a distinction between 
TH and PH, "R00-R99 Symptoms, signs and abnormal clinical and laboratory findings, not elsewhere classified" constitutes $38,41 \%$ of all diagnosis in TH. Meanwhile, $\mathrm{PH}$ have $16.87 \%$ of the diagnoses for the same ICD 10 code range. In PH, the most diagnosed category is "J00-J99 Diseases of the respiratory system" with 36.09\% (Table 32, $33,34)$.

$81.63 \%$ of the diagnoses in diseases of the respiratory system are acute upper respiratory infections which have a code range between $\mathrm{J} 00$ and $\mathrm{J} 11$. This disease group with almost $25 \%$ of total visits can be accepted as the most common cause of EDV (Table 35).

The most diagnosed disease is $\mathrm{J03}$ acute tonsillitis with $5.95 \%$. $\mathrm{J} 03$ rate is $8.4 \%$ in $\mathrm{TH}$ and $1.84 \%$ in $\mathrm{PH}$. However, for the $0-12$ month old group where acute tonsillitis is almost never observed the $\mathrm{J} 03 \mathrm{di}$ agnosis rate is $9.4 \%$. This situation suggests that especially in $\mathrm{TH} \mathrm{J03}$ diagnosis code is used incorrectly (Table 36, 37, 38, 39).

The whole list about major disease groups, the mostly diagnosed diseases, their distribution among hospital type, patient gender and ages and detailed diagnosis lists are presented in Tables 32, 33, 34, 35, 36, 37, 38, 39.

"V01-Y98 External causes of morbidity and mortality" is the 3rd category with the most diagnosis. These codes starting with $\mathrm{V}, \mathrm{W}$, $X, Y$ are used for injuries, poisoning and other external causes. These codes should accompany "S00-T98 - Injury, poisoning and certain other consequences of external causes" codes and not used alone or as the main diagnosis. But because of user errors and insufficient coding education, they are widely used as the main diagnosis in trauma cases.

In this category, 191,504 diagnoses were made for 190,306 visits. $67.19 \%$ of all ED visits and $80.6 \%$ of trauma patient visits were in the TH (Table 40). Okmeydanı TH by itself has provided healthcare to approximately $41 \%$ of trauma patients. Almost half of the visits caused by trauma got diagnosed as "W01 - Fall on same level from slipping, tripping and stumbling and W19 - Unspecified fall" (Table 41).

$61.48 \%$ of trauma patients consist of males. The ages between 25 and 44 make up 33.2\% the trauma visits (Table 42). Males in 15-24 age group and females in 65+ age group come to attention with their higher visit rates in comparison to the other groups. Detailed information in this category can be seen in Tables 40, 41, 42, 43.

If evaluated from a perspective of using the diagnosis codes correctly, nearly $44 \%$ of the $65+$ age group is diagnosed with "W84 Unspecified threat to breathing" $(31,69 \%)$ and "W83 - Other specified threats to breathing" $(12,24 \%)$. We know that this is not realistic. These diagnosis codes are used for situations where breathing is affected by e.g. accidentally swallowing objects. The fact that $44 \%$ of trauma related visits in patients with ages of 65 or above are recorded under these codes makes us think of incorrect coding. The situation can be explained by patients with breathing difficulties caused by chronic obstructive pulmonary disease or asthma who are recorded with the wrong diagnosis code.

Table 28. Distribution of Emergency Department Frequent Visits by Number of Presentation (\%) BKHB 2014

\begin{tabular}{|l|c|c|c|c|c|c|c|c|}
\hline & $\mathbf{1}$ & $\mathbf{2}$ & $\mathbf{3}$ & $\mathbf{4}$ & $\mathbf{5 - 9}$ & $\mathbf{1 0 - 2 0}$ & $\mathbf{2 0 +}$ & Total \\
\hline All Hospitals & 36.69 & 19.99 & 11.94 & 7.91 & 16.07 & 5.97 & 1.44 & 100.00 \\
\hline Teaching Hospitals & 36.73 & 19.74 & 11.78 & 7.84 & 16.20 & 6.24 & 1.46 & 100.00 \\
\hline Okmeydanı & 32.14 & 18.88 & 12.30 & 8.46 & 19.05 & 7.51 & 1.66 & 100.00 \\
\hline Şişli Hamidiye Etfal & 44.41 & 21.54 & 11.42 & 7.27 & 11.76 & 2.97 & 0.62 & 100.00 \\
\hline GOP Taksim & 37.52 & 19.39 & 10.99 & 7.13 & 15.26 & 7.59 & 2.12 & 100.00 \\
\hline Secondary Care Hospitals & 36.60 & 20.50 & 12.28 & 8.04 & 15.80 & 5.39 & 1.39 & 100.00 \\
\hline Eyüp & 43.50 & 21.92 & 11.53 & 6.76 & 11.59 & 3.70 & 0.99 & 100.00 \\
\hline İstinye & 30.43 & 18.05 & 11.89 & 8.76 & 20.32 & 8.27 & 2.29 & 100.00 \\
\hline Kâğı̆ınane & 41.54 & 22.73 & 12.66 & 7.63 & 11.98 & 2.78 & 0.68 & 100.00 \\
\hline Sarıyer İsmail Akgün & 27.30 & 19.27 & 14.14 & 9.93 & 21.06 & 6.86 & 1.44 & 100.00 \\
\hline
\end{tabular}

Table 29. Distribution of Emergency Department Frequent Visitors by Number of Presentation (\%) BKHB 2014

\begin{tabular}{|l|c|c|c|c|c|c|c|c|}
\hline & $\mathbf{1}$ & $\mathbf{2}$ & $\mathbf{3}$ & $\mathbf{4}$ & $\mathbf{5 - 9}$ & $\mathbf{1 0 - 2 0}$ & $\mathbf{2 0 +}$ & Total \\
\hline All Hospitals & 65.78 & 17.92 & 7.14 & 3.54 & 4.68 & 0.85 & 0.09 & 100.00 \\
\hline Teaching Hospitals & 65.99 & 17.73 & 7.05 & 3.52 & 4.71 & 0.90 & 0.09 & 100.00 \\
\hline Okmeydanı & 62.37 & 18.32 & 7.96 & 4.10 & 5.97 & 1.16 & 0.11 & 100.00 \\
\hline Şişli Hamidiye Etfal & 70.48 & 17.10 & 6.04 & 2.88 & 3.08 & 0.38 & 0.03 & 100.00 \\
\hline GOP Taksim & 67.35 & 17.40 & 6.58 & 3.20 & 4.39 & 1.07 & 0.13 & 100.00 \\
\hline Secondary Care Hospitals & 65.35 & 18.30 & 7.31 & 3.59 & 4.59 & 0.77 & 0.08 & 100.00 \\
\hline Eyüp & 69.92 & 17.62 & 6.18 & 2.72 & 3.04 & 0.47 & 0.05 & 100.00 \\
\hline İstinye & 61.34 & 18.20 & 7.99 & 4.42 & 6.59 & 1.32 & 0.15 & 100.00 \\
\hline Kâğı̆thane & 67.78 & 18.54 & 6.89 & 3.11 & 3.27 & 0.37 & 0.03 & 100.00 \\
\hline Sarıyer İsmail Akgün & 56.68 & 20.01 & 9.78 & 5.15 & 7.12 & 1.15 & 0.11 & 100.00 \\
\hline
\end{tabular}


Table 30. Distribution of Emergency Department Frequent Visits by Age and Gender (\%) BKHB 2014

\begin{tabular}{|c|c|c|c|c|c|c|c|}
\hline & 1 & 2 & 3 & 4 & $5-9$ & $10-20$ & $20+$ \\
\hline Total & 100.00 & 100.00 & 100.00 & 100.00 & 100.00 & 100.00 & 100.00 \\
\hline Female & 48.34 & 49.91 & 51.67 & 51.96 & 52.90 & 51.72 & 42.60 \\
\hline Male & 51.66 & 50.09 & 48.33 & 48.04 & 47.10 & 48.28 & 57.40 \\
\hline Under 15 Years & 20.36 & 22.10 & 24.82 & 26.65 & 29.47 & 29.64 & 16.89 \\
\hline Under 1 Year & 1.58 & 1.51 & 1.64 & 1.69 & 1.93 & 1.50 & 0.52 \\
\hline 1-4 Years & 6.96 & 7.90 & 9.84 & 11.65 & 14.50 & 17.90 & 12.56 \\
\hline 5-14 Years & 11.82 & 12.68 & 13.35 & 13.31 & 13.03 & 10.24 & 3.80 \\
\hline 15-24 Years & 18.74 & 18.14 & 17.70 & 17.55 & 16.38 & 15.69 & 9.28 \\
\hline 25-44 Years & 35.77 & 35.57 & 34.00 & 33.30 & 31.31 & 29.03 & 28.94 \\
\hline 45-64 Years & 17.99 & 17.13 & 16.51 & 15.52 & 15.71 & 17.15 & 25.74 \\
\hline 65 Years and Over & 7.14 & 7.06 & 6.97 & 6.98 & 7.13 & 8.49 & 19.15 \\
\hline 65-74 Years & 3.99 & 3.86 & 3.84 & 3.74 & 4.07 & 4.99 & 11.59 \\
\hline 75 Years and Over & 3.15 & 3.20 & 3.13 & 3.24 & 3.05 & 3.50 & 7.56 \\
\hline \multicolumn{8}{|l|}{ Gender and Age } \\
\hline Female & 100.00 & 100.00 & 100.00 & 100.00 & 100.00 & 100.00 & 100.00 \\
\hline Under 15 Years & 20.04 & 19.98 & 21.44 & 22.55 & 24.57 & 23.94 & 12.45 \\
\hline Under 1 Year & 1.52 & 1.43 & 1.45 & 1.35 & 1.51 & 1.22 & 0.00 \\
\hline 1-4 Years & 7.51 & 7.24 & 8.60 & 9.70 & 11.86 & 13.82 & 9.00 \\
\hline 5-14 Years & 11.01 & 11.31 & 11.39 & 11.50 & 11.21 & 8.90 & 3.46 \\
\hline 15-24 Years & 17.76 & 17.35 & 17.53 & 17.33 & 17.21 & 17.11 & 13.12 \\
\hline 25-44 Years & 33.52 & 35.13 & 34.70 & 34.87 & 33.39 & 32.64 & 34.82 \\
\hline 45-64 Years & 19.85 & 19.06 & 18.48 & 17.47 & 17.61 & 18.36 & 25.64 \\
\hline 65 Years and Over & 8.83 & 8.48 & 7.85 & 7.77 & 7.21 & 7.94 & 13.96 \\
\hline 65-74 Years & 4.81 & 4.54 & 4.27 & 4.18 & 4.21 & 4.71 & 9.99 \\
\hline 75 Years and Over & 4.01 & 3.94 & 3.58 & 3.60 & 3.00 & 3.23 & 3.96 \\
\hline Male & 100.00 & 100.00 & 100.00 & 100.00 & 100.00 & 100.00 & 100.00 \\
\hline Under 15 Years & 20.66 & 24.21 & 28.44 & 31.09 & 34.96 & 35.74 & 20.18 \\
\hline Under 1 Year & 1.64 & 1.60 & 1.84 & 2.07 & 2.41 & 1.79 & 0.91 \\
\hline 1-4 Years & 6.44 & 8.56 & 11.16 & 13.76 & 17.46 & 22.27 & 15.21 \\
\hline 5-14 Years & 12.58 & 14.05 & 15.44 & 15.26 & 15.08 & 11.68 & 4.06 \\
\hline 15-24 Years & 19.65 & 18.93 & 17.88 & 17.79 & 15.46 & 14.17 & 6.43 \\
\hline 25-44 Years & 37.88 & 36.00 & 33.25 & 31.60 & 28.97 & 25.16 & 24.57 \\
\hline 45-64 Years & 16.26 & 15.21 & 14.40 & 13.40 & 13.57 & 15.85 & 25.81 \\
\hline 65 Years and Over & 5.55 & 5.64 & 6.03 & 6.12 & 7.04 & 9.08 & 23.00 \\
\hline $65-74$ Years & 3.21 & 3.18 & 3.38 & 3.27 & 3.92 & 5.29 & 12.78 \\
\hline 75 Years and Over & 2.34 & 2.46 & 2.65 & 2.85 & 3.12 & 3.79 & 10.23 \\
\hline
\end{tabular}




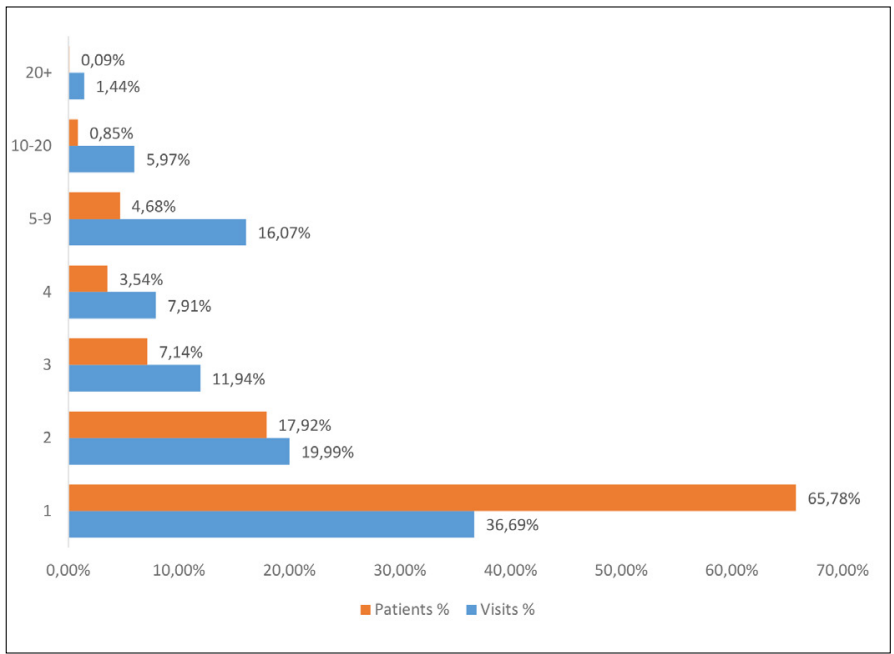

Figure 8. Rate of frequent visits and frequent presenters based on number of visit, BKHB 2014

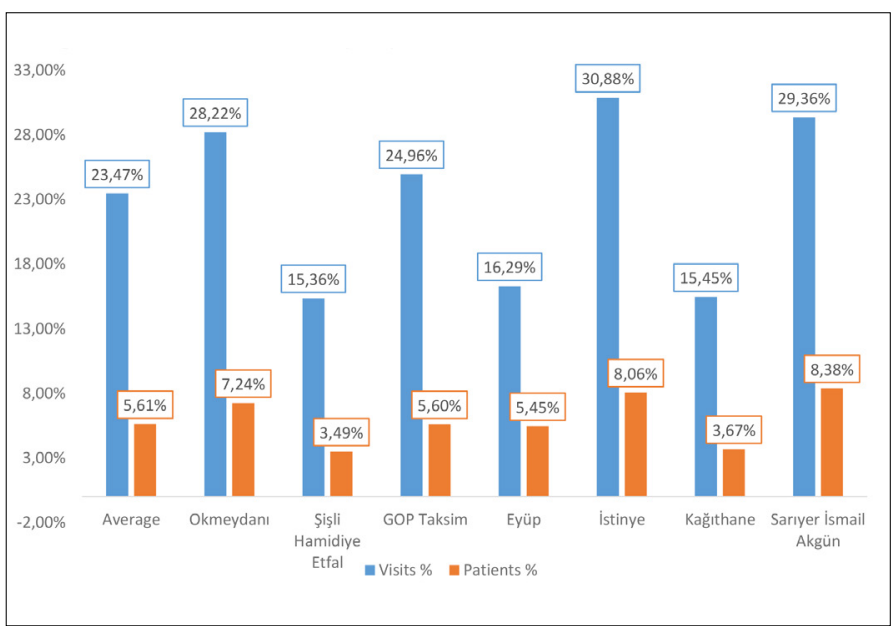

Figure 9. Rate of 5 or more visits by hospital, BKHB 2014

Table 31. Distribution of Emergency Department Readmissions within 24 and 72 Hours (\%) BKHB 2014

\begin{tabular}{|l|c|c|}
\hline & $\begin{array}{c}\mathbf{2 4} \\
\text { Hours (\%) }\end{array}$ & $\begin{array}{c}\mathbf{7 2} \\
\text { Hours (\%) }\end{array}$ \\
\hline All Hospitals & 1.56 & 3.62 \\
\hline Teaching Hospitals & 1.62 & 3.53 \\
\hline Okmeydanı & 1.16 & 3.56 \\
\hline Şişli Hamidiye Etfal & 1.95 & 2.86 \\
\hline GOP Taksim & 2.15 & 4.49 \\
\hline Secondary Care Hospitals & 1.44 & 3.81 \\
\hline Eyüp & 1.46 & 3.31 \\
\hline İstinye & 1.04 & 5.70 \\
\hline Kâğıthane & 1.72 & 3.17 \\
\hline Sarıer İsmail Akgün & 1.67 & 2.52 \\
\hline
\end{tabular}

\section{DIAGNOSTIC AND THERAPEUTIC PROCEDURES IN EMERGENCY DEPARTMENT VISITS}

The procedures performed in ED are presented with their SUT submission names in our survey. The first thing that stands out regarding diagnostic procedures is the numbers of procedures done in $\mathrm{TH}$ are higher than the ones in $\mathrm{PH}$ (Table 44, 45, 46). 32.81\% of the patients admitted to our PH but only $8.09 \%$ of the test were ordered in PH. Also, there are some differences in the types of tests that were ordered. The most frequent test is "Complete Blood Count".

$87.40 \%$ of the imaging procedures are carried out in $\mathrm{TH}$. About $89 \%$ of the imaging carried out in PH is X-ray and it is seen that the other techniques are rarely used. The details regarding the imaging tests can be seen in Table 47, 48, 49, 50 .

Table 51, 52, 53 present both diagnostic and therapeutic procedures and are prepared based on SUT names. Intramuscular and intravenous injections make up $75 \%$ of the total. Intramuscular injection forms almost half of the procedures carried out and they reach $68 \%$ in $\mathrm{PH}$. Intravenous treatments are mostly preferred in $\mathrm{TH}$. The most frequently used diagnosis-oriented procedure is ECG.

When the number of EDV, and type and number of procedures are compared, we can easily see the rate of procedures that would be considered as real emergency treatments is insignificant. This is another indication that the degree of urgency is low and inappropriate visits are high.

The number of drugs used in ED shown in Table 54 is calculated using stock numbers and only includes Kâğıthane and Sarıyer PH data. Although numbers of drugs administered are approximate values, they reveal a realistic picture.

Table 55 displays the list of most frequently prescribed drugs in ED based on electronic prescription. Because paper based prescriptions are widely used, our list of drugs is not all inclusive. Especially in $\mathrm{TH}$, rate of electronic prescription is very low and makes up only $8.45 \%$ of the drugs in our list. However type of drugs that are prescribed most in ED is in line with the most diagnosed disease category which is the upper respiratory track infections.

$97 \%$ of the patients are discharged home after being treated in ED. The mortality rate is only $0.02 \%$ (Table 56 ). There is no statistically significant difference between $\mathrm{TH}$ and $\mathrm{PH}$ in terms of mortality rate (Mann-Whitney'u test p: 0.15 and $\mathrm{p}>0.05$ )

The average of admission to inpatient clinics from ED is $3.43 \%$ for $\mathrm{TH}$ and $0.43 \%$ for $\mathrm{PH}$. There is a statistically significant difference in the admitted patient rates between TH and PH (Mann-Whitney'u test $\mathrm{p}: 0.034$ and $\mathrm{p}<0.05$ ).

When compared with international statistics, it is seen that the admission rate is very low in our country. The admission rate of the patients visiting ED is $12 \%$ in the US (2), $21 \%$ in Britain (14) and $28 \%$ in Australia (3). This situation shows that the ED in our country aren't utilized for emergency treatment and supports the argument that our ED are used inappropriately by the patients who need to be cared by primary care physicians. 
Table 32. Distribution of Diagnosis at Emergency Department Visits According to the Major Diagnostic Categories (\%), BKHB 2014

\begin{tabular}{|c|c|c|}
\hline Diagnosis Categories & $\begin{array}{l}\text { Number of } \\
\text { Diagnosis }\end{array}$ & $\%$ \\
\hline Total & $2,233,905$ & 100.00 \\
\hline A00-B99 Certain infectious and parasitic diseases & 50,080 & 2.24 \\
\hline C00-D48 Neoplasms & 1,623 & 0.07 \\
\hline $\begin{array}{l}\text { D50-D89 Diseases of the blood and } \\
\text { blood-forming organs and certain disorders } \\
\text { involving the immune mechanism }\end{array}$ & 5,945 & 0.27 \\
\hline $\begin{array}{l}\text { E00-E90 Endocrine, nutritional and metabolic } \\
\text { diseases }\end{array}$ & 7,599 & 0.34 \\
\hline F00-F99 Mental and behavioural disorders & 17,179 & 0.77 \\
\hline G00-G99 Diseases of the nervous system & 16,317 & 0.73 \\
\hline H00-H59 Diseases of the eye and adnexa & 22,325 & 1.00 \\
\hline H60-H95 Diseases of the ear and mastoid process & 21,904 & 0.98 \\
\hline I00-I99 Diseases of the circulatory system & 33,586 & 1.50 \\
\hline J00-J99 Diseases of the respiratory system & 667,353 & 29.87 \\
\hline K00-K93 Diseases of the digestive system & 68,269 & 3.06 \\
\hline $\begin{array}{l}\text { L00-L99 Diseases of the skin and subcutaneous } \\
\text { tissue }\end{array}$ & 30,101 & 1.35 \\
\hline $\begin{array}{l}\text { M00-M99 Diseases of the musculoskeletal } \\
\text { system and connective tissue }\end{array}$ & 180,245 & 8.07 \\
\hline M800-M998 Neoplazmların Morfolojisi & 46 & 0.00 \\
\hline N00-N99 Diseases of the genitourinary system & 94,158 & 4.21 \\
\hline O00-099 Pregnancy, childbirth and the puerperium & 10,928 & 0.49 \\
\hline $\begin{array}{l}\text { P00-P96 Certain conditions originating in the } \\
\text { perinatal period }\end{array}$ & 6,499 & 0.29 \\
\hline $\begin{array}{l}\text { Q00-Q99 Congenital malformations, } \\
\text { deformations and chromosomal abnormalities }\end{array}$ & 624 & 0.03 \\
\hline $\begin{array}{l}\text { R00-R99 Symptoms, signs and abnormal clinical } \\
\text { and laboratory findings, not elsewhere classified }\end{array}$ & 678.172 & 30.36 \\
\hline $\begin{array}{l}\text { S00-T98 Injury, poisoning and certain other } \\
\text { consequences of external causes }\end{array}$ & 73,974 & 3.31 \\
\hline U00-U99 Codes for special purposes & 2 & 0.00 \\
\hline V01-Y98 External causes of morbidity and mortality & 191,574 & 8.58 \\
\hline $\begin{array}{l}\text { Z00-Z99 Factors influencing health status and } \\
\text { contact with health services }\end{array}$ & 55,402 & 2.48 \\
\hline
\end{tabular}

Table 33. Distribution of Diagnosis at Emergency Department Visits According to the Major Diagnostic Categories (\%), BKHB Teaching Hospitals 2014

\begin{tabular}{|c|c|c|}
\hline Diagnosis Categories & $\begin{array}{l}\text { Number of } \\
\text { Diagnosis }\end{array}$ & $\%$ \\
\hline Total & $1,399,163$ & 100.00 \\
\hline A00-B99 Certain infectious and parasitic diseases & 9,442 & 0.67 \\
\hline C00-D48 Neoplasms & 977 & 0.07 \\
\hline $\begin{array}{l}\text { D50-D89 Diseases of the blood and } \\
\text { blood-forming organs and certain disorders } \\
\text { involving the immune mechanism }\end{array}$ & 3,127 & 0.22 \\
\hline $\begin{array}{l}\text { E00-E90 Endocrine, nutritional and metabolic } \\
\text { diseases }\end{array}$ & 1,119 & 0.08 \\
\hline F00-F99 Mental and behavioural disorders & 2,798 & 0.20 \\
\hline G00-G99 Diseases of the nervous system & 11,827 & 0.85 \\
\hline H00-H59 Diseases of the eye and adnexa & 14,704 & 1.050 \\
\hline H60-H95 Diseases of the ear and mastoid process & 12,677 & 0.91 \\
\hline 100-199 Diseases of the circulatory system & 11,217 & 0.80 \\
\hline J00-J99 Diseases of the respiratory system & 366,111 & 26.17 \\
\hline K00-K93 Diseases of the digestive system & 27,381 & 1.96 \\
\hline $\begin{array}{l}\text { L00-L99 Diseases of the skin and subcutaneous } \\
\text { tissue }\end{array}$ & 12,794 & 0.91 \\
\hline $\begin{array}{l}\text { M00-M99 Diseases of the musculoskeletal } \\
\text { system and connective tissue }\end{array}$ & 92,971 & 6.64 \\
\hline M800-M998 Neoplazmların Morfolojisi & 1 & 0.00 \\
\hline N00-N99 Diseases of the genitourinary system & 59,969 & 4.29 \\
\hline 000-099 Pregnancy, childbirth and the puerperium & 10,675 & 0.76 \\
\hline $\begin{array}{l}\text { P00-P96 Certain conditions originating in the } \\
\text { perinatal period }\end{array}$ & 6,445 & 0.46 \\
\hline $\begin{array}{l}\text { Q00-Q99 Congenital malformations, } \\
\text { deformations and chromosomal abnormalities }\end{array}$ & 488 & 0.03 \\
\hline $\begin{array}{l}\text { R00-R99 Symptoms, signs and abnormal clinical } \\
\text { and laboratory findings, not elsewhere classified }\end{array}$ & 537,367 & 38.41 \\
\hline $\begin{array}{l}\text { S00-T98 Injury, poisoning and certain other } \\
\text { consequences of external causes }\end{array}$ & 47,330 & 3.38 \\
\hline U00-U99 Codes for special purposes & 2 & 0.00 \\
\hline V01-Y98 External causes of morbidity and mortality & 154,135 & 11.02 \\
\hline $\begin{array}{l}\text { Z00-Z99 Factors influencing health status and } \\
\text { contact with health services }\end{array}$ & 15,606 & 1.12 \\
\hline
\end{tabular}


Table 34. Distribution of Diagnosis at Emergency Department Visits According to the Major Diagnostic Categories (\%), BKHB Secondary Care Hospitals 2014

\begin{tabular}{|c|c|c|}
\hline Diagnosis Categories & $\begin{array}{l}\text { Number of } \\
\text { Diagnosis }\end{array}$ & $\%$ \\
\hline Total & 834,742 & 100.00 \\
\hline A00-B99 Certain infectious and parasitic diseases & 40,638 & 4.87 \\
\hline C00-D48 Neoplasms & 646 & 0.08 \\
\hline $\begin{array}{l}\text { D50-D89 Diseases of the blood and } \\
\text { blood-forming organs and certain disorders } \\
\text { involving the immune mechanism }\end{array}$ & 2,818 & 0.34 \\
\hline $\begin{array}{l}\text { E00-E90 Endocrine, nutritional and metabolic } \\
\text { diseases }\end{array}$ & 6,480 & 0.78 \\
\hline F00-F99 Mental and behavioural disorders & 14,381 & 1.72 \\
\hline G00-G99 Diseases of the nervous system & 4,490 & 0.54 \\
\hline H00-H59 Diseases of the eye and adnexa & 7,621 & 0.91 \\
\hline H60-H95 Diseases of the ear and mastoid process & 9,227 & 1.11 \\
\hline 100-199 Diseases of the circulatory system & 22,369 & 2.68 \\
\hline J00-J99 Diseases of the respiratory system & 301,242 & 36.09 \\
\hline K00-K93 Diseases of the digestive system & 40,888 & 4.90 \\
\hline $\begin{array}{l}\text { L00-L99 Diseases of the skin and subcutaneous } \\
\text { tissue }\end{array}$ & 17,307 & 2.07 \\
\hline $\begin{array}{l}\text { M00-M99 Diseases of the musculoskeletal } \\
\text { system and connective tissue }\end{array}$ & 87,274 & 10.46 \\
\hline M800-M998 Neoplazmların Morfolojisi & 45 & 0.01 \\
\hline N00-N99 Diseases of the genitourinary system & 34,189 & 4.10 \\
\hline O00-099 Pregnancy, childbirth and the puerperium & 253 & 0.03 \\
\hline $\begin{array}{l}\text { P00-P96 Certain conditions originating in the } \\
\text { perinatal period }\end{array}$ & 54 & 0.01 \\
\hline $\begin{array}{l}\text { Q00-Q99 Congenital malformations, } \\
\text { deformations and chromosomal abnormalities }\end{array}$ & 136 & 0.02 \\
\hline $\begin{array}{l}\text { R00-R99 Symptoms, signs and abnormal clinical } \\
\text { and laboratory findings, not elsewhere classified }\end{array}$ & 140,805 & 16.87 \\
\hline $\begin{array}{l}\text { S00-T98 Injury, poisoning and certain other } \\
\text { consequences of external causes }\end{array}$ & 26,644 & 3.19 \\
\hline V01-Y98 External causes of morbidity and mortality & 37,439 & 4.49 \\
\hline $\begin{array}{l}\text { Z00-Z99 Factors influencing health status and } \\
\text { contact with health services }\end{array}$ & 39,796 & 4.77 \\
\hline
\end{tabular}

Table 35. 5 Leading Diagnosis within each Major Diagnostic Categories (\%)

\begin{tabular}{|c|c|c|}
\hline Diagnosis Categories / ICD Code & $\begin{array}{l}\text { Number of } \\
\text { Diagnosis }\end{array}$ & $\%$ \\
\hline A00-B99 Certain infectious and parasitic diseases & 50,080 & 100.00 \\
\hline B87.1 - Wound myiasis & 17,195 & 34.34 \\
\hline A09-Infectious gastroenteritis and colitis, unspecified & 12,718 & 25.40 \\
\hline A08.4-Viral intestinal infection, unspecified & 5,187 & 10.36 \\
\hline A04.9-Bacterial intestinal infection, unspecified & 5,180 & 10.34 \\
\hline $\begin{array}{l}\text { A05.8-Other specified bacterial foodborne } \\
\text { intoxications }\end{array}$ & 1,110 & 2.22 \\
\hline Other diagnoses & 8,690 & 17.35 \\
\hline 100-199 Diseases of the circulatory system & 33,586 & 100.00 \\
\hline I10 - Essential (primary) hypertension & 22,165 & 65.99 \\
\hline 195 - Hypotension & 1,860 & 5.54 \\
\hline I84 - Hemorrhoids & 1,754 & 5.22 \\
\hline 195.9- Hypotension, unspecified & 1,105 & 3.29 \\
\hline $\begin{array}{l}\text { I84.9- Unspecified Hemorrhoids without mention } \\
\text { of complication }\end{array}$ & 619 & 1.84 \\
\hline Other diagnoses & 6,083 & 18.11 \\
\hline J00-J99 Diseases of the respiratory system & 667,353 & 100.00 \\
\hline J03 - Acute tonsillitis & 132,918 & 19.92 \\
\hline J06.9 - Acute upper respiratory infection, unspecified & 121,017 & 18.13 \\
\hline J02 - Acute pharyngitis & 101,012 & 15.14 \\
\hline $\begin{array}{l}\text { J06 - Acute upper respiratory infections of multiple } \\
\text { and unspecified sites }\end{array}$ & 95,686 & 14.34 \\
\hline J00 - Acute nasopharyngitis [common cold] & 35,891 & 5.38 \\
\hline Other diagnoses & 180,829 & 27.10 \\
\hline K00-K93 Diseases of the digestive system & 68,269 & 100 \\
\hline $\begin{array}{l}\text { K52.9- Noninfective gastroenteritis and colitis, } \\
\text { unspecified }\end{array}$ & 11,223 & 16.44 \\
\hline K30 - Functional dyspepsia & 9,059 & 13.27 \\
\hline $\begin{array}{l}\text { K52.8 - Other specified noninfective gastroenteritis } \\
\text { and colitis }\end{array}$ & 7,918 & 11.60 \\
\hline K21 - Gastro-esophageal reflux & 4,737 & 6.94 \\
\hline K59.0 - Constipation & 4,549 & 6.66 \\
\hline Other diagnoses & 30,783 & 45.09 \\
\hline L00-L99 Diseases of the skin and subcutaneou & 30,101 & 100.00 \\
\hline L50 - Urticaria & 6,983 & 23.20 \\
\hline L50.9 - Urticaria, unspecified & 6,186 & 20.55 \\
\hline L30.9 - Dermatitis, unspecified & 2,308 & 7.67 \\
\hline $\begin{array}{l}\text { L08.9- Local infection of the skin and subcutaneous } \\
\text { tissue, unspecified }\end{array}$ & 1,873 & 6.22 \\
\hline L30 - Other and unspecified dermatitis & 1,680 & 5.58 \\
\hline Other diagnoses & 11,071 & 36.78 \\
\hline
\end{tabular}


Table 35. 5 Leading Diagnosis within each Major Diagnostic Categories (\%)

\begin{tabular}{|c|c|c|}
\hline Diagnosis Categories / ICD Code & $\begin{array}{l}\text { Number of } \\
\text { Diagnosis }\end{array}$ & $\%$ \\
\hline $\begin{array}{l}\text { M00-M99 Diseases of the musculoskeletal system } \\
\text { and connective tissue }\end{array}$ & 180,245 & 100.00 \\
\hline M79.1 - Myalgia & 46,842 & 25.99 \\
\hline M54.5 - Low back pain & 30,502 & 16.92 \\
\hline M25.5 - Pain in joint & 16,106 & 8.94 \\
\hline M79.9 - Soft tissue disorder, unspecified & 15,575 & 8.64 \\
\hline M79.8 - Other specified soft tissue disorders & 12,785 & 7.09 \\
\hline Other diagnoses & 58,435 & 32.42 \\
\hline N00-N99 Diseases of the genitourinary system & 94,158 & 100.00 \\
\hline N39.0 - Urinary tract infection, site not specified & 20,259 & 21.52 \\
\hline N23 - Unspecified renal colic & 12,184 & 12.94 \\
\hline N30.0 - Acute cystitis & 9,940 & 10.56 \\
\hline N91 - Absent, scanty and rare menstruation & 9,792 & 10.40 \\
\hline N94.6 - Dysmenorrhea, unspecified & 5,422 & 5.76 \\
\hline Other diagnoses & 32,191 & 34.19 \\
\hline $\begin{array}{l}\text { R00-R99 Symptoms, signs and abnormal clinical and } \\
\text { laboratory findings, not elsewhere classified }\end{array}$ & 678,172 & 100.00 \\
\hline R10.4 - Other and unspecified abdominal pain & 100,321 & 14.79 \\
\hline R52 - Pain, unspecified & 93,666 & 13.81 \\
\hline R11 - Nausea and vomiting & 90,733 & 13.38 \\
\hline R53 - Malaise and fatigue & 56,456 & 8.32 \\
\hline R51 - Headache & 52,700 & 7.77 \\
\hline Other diagnoses & 284,296 & 41.92 \\
\hline $\begin{array}{l}\text { S00-T98 Injury, poisoning and certain other } \\
\text { consequences of external causes }\end{array}$ & 73,974 & 100.00 \\
\hline T78.4 - Other and unspecified allergy & 12,848 & 17.37 \\
\hline S93.4 - Sprain of ankle & 6,725 & 9.09 \\
\hline S63.5 - Other and unspecified sprain of wrist & 5,268 & 7.12 \\
\hline T15 - Foreign body on external eye & 3,869 & 5.23 \\
\hline S06.9- Unspecified intracranial injury & 3,817 & 5.16 \\
\hline Other diagnoses & 41,447 & 56.03 \\
\hline $\begin{array}{l}\text { Z00-Z99 Factors influencing health status and contact } \\
\text { with health services }\end{array}$ & 55,402 & 100.00 \\
\hline $\begin{array}{l}\text { Z00.0 - Encounter for general adult medical } \\
\text { examination }\end{array}$ & 31,679 & 57.18 \\
\hline Z00.8 - Encounter for other general examination & 8,851 & 15.98 \\
\hline $\begin{array}{l}\text { Z04.1 - Encounter for examination and observation } \\
\text { following transport accident }\end{array}$ & 3,309 & 5.97 \\
\hline Z33 - Pregnant state & 2,016 & 3.64 \\
\hline $\begin{array}{l}\text { Z04.2 - Encounter for examination and observation } \\
\text { following work accident }\end{array}$ & 1,326 & 2.39 \\
\hline Other diagnoses & 8,221 & 14.84 \\
\hline
\end{tabular}

Table 36. Number and Distribution of 40 Leading Diagnosis for Emergency Department Visits (\%), BKHB 2014

\begin{tabular}{|c|c|c|}
\hline ICD-10 Diagnosis Code & $\begin{array}{l}\text { Number of } \\
\text { Diagnosis }\end{array}$ & $\%$ \\
\hline J03-Acute tonsillitis & 132,929 & 5.95 \\
\hline J06,9 - Acute upper respiratory infection, unspecified & 120,994 & 5.42 \\
\hline J02 - Acute pharyngitis & 101,012 & 4.52 \\
\hline R10,4- Other and unspecified abdominal pain & 100,326 & 4.49 \\
\hline $\begin{array}{l}\text { J06 - Acute upper respiratory infections of multiple } \\
\text { and unspecified sites }\end{array}$ & 95,629 & 4.28 \\
\hline R52 - Pain, unspecified & 93,660 & 4.19 \\
\hline R11 - Nausea and vomiting & 90,734 & 4.06 \\
\hline R53 - Malaise and fatigue & 56,459 & 2.53 \\
\hline R51 - Headache & 52,696 & 2.36 \\
\hline $\begin{array}{l}\text { W01 - Fall on same level from slipping, tripping and } \\
\text { stumbling }\end{array}$ & 51,533 & 2.31 \\
\hline M79,1 - Myalgia & 46,836 & 2.10 \\
\hline W19- Unspecified fall & 42,475 & 1.90 \\
\hline R07,4 - Pain in chest, unspecified & 41,622 & 1.86 \\
\hline J00 - Acute nasopharyngitis [common cold] & 35,882 & 1.61 \\
\hline R10-Abdominal and pelvic pain & 34,955 & 1.56 \\
\hline R05 - Cough & 34,813 & 1.56 \\
\hline J39- Other diseases of upper respiratory tract & 33,360 & 1.49 \\
\hline $\begin{array}{l}\text { Z00,0 - Encounter for general adult medical } \\
\text { examination }\end{array}$ & 31,554 & 1.41 \\
\hline M54,5 - Low back pain & 30,501 & 1.37 \\
\hline J02,9 - Acute pharyngitis, unspecified & 29,674 & 1.33 \\
\hline R42 - Dizziness and giddiness & 28,101 & 1.26 \\
\hline R52,0 - Acute pain & 23,527 & 1.05 \\
\hline R52,9- Pain, unspecified & 23,210 & 1.04 \\
\hline J39,9 - Disease of upper respiratory tract, unspecified & 22,288 & 1.00 \\
\hline I10 - Essential (primary) hypertension & 22,165 & 0.99 \\
\hline N39,0 - Urinary tract infection, site not specified & 20,259 & 0.91 \\
\hline B87,1 - Wound myiasis & 17,195 & 0.77 \\
\hline M25,5 - Pain in joint & 16,104 & 0.72 \\
\hline M79,9-Soft tissue disorder, unspecified & 15,575 & 0.70 \\
\hline J20 - Acute bronchitis & 15,505 & 0.69 \\
\hline $\begin{array}{l}\text { W51 - Accidental striking against or bumped into by } \\
\text { another person }\end{array}$ & 15,350 & 0.69 \\
\hline R07,3 - Other chest pain & 14,435 & 0.65 \\
\hline W84- Unspecified threat to breathing & 14,230 & 0.64 \\
\hline R50 - Fever of other and unknown origin & 13,553 & 0.61 \\
\hline J03,9-Acute tonsillitis, unspecified & 12,992 & 0.58 \\
\hline T78,4 - Other and unspecified allergy & 12,849 & 0.58 \\
\hline M79,8 - Other specified soft tissue disorders & 12,785 & 0.57 \\
\hline A09-Infectious gastroenteritis and colitis, unspecified & 12,716 & 0.57 \\
\hline Y35 - Legal intervention & 12,686 & 0.57 \\
\hline N23 - Unspecified renal colic & 12,186 & 0.55 \\
\hline Other diagnoses & 638,550 & 28.58 \\
\hline
\end{tabular}


Table 37. Number and Distribution of 40 Leading Diagnosis for Emergency Department Visits (\%), BKHB Teaching Hospitals 2014

\begin{tabular}{|c|c|c|}
\hline ICD-10 Diagnosis Code & $\begin{array}{l}\text { Number of } \\
\text { Diagnosis }\end{array}$ & $\%$ \\
\hline J03 - Acute tonsillitis & 117,586 & 8.40 \\
\hline R52 - Pain, unspecified & 93,277 & 6.67 \\
\hline $\begin{array}{l}\text { J06 - Acute upper respiratory infections of multiple } \\
\text { and unspecified sites }\end{array}$ & 86,301 & 6.17 \\
\hline R10,4 - Other and unspecified abdominal pain & 71,118 & 5.08 \\
\hline R11 - Nausea and vomiting & 66,418 & 4.75 \\
\hline R53 - Malaise and fatigue & 55,443 & 3.96 \\
\hline $\begin{array}{l}\text { W01 - Fall on same level from slipping, tripping and } \\
\text { stumbling }\end{array}$ & 44,899 & 3.21 \\
\hline R10 - Abdominal and pelvic pain & 34,310 & 2.45 \\
\hline J02 - Acute pharyngitis & 33,936 & 2.43 \\
\hline R05 - Cough & 31,684 & 2.26 \\
\hline J39- Other diseases of upper respiratory tract & 31,398 & 2.24 \\
\hline W19- Unspecified fall & 26,562 & 1.90 \\
\hline R51 - Headache & 25,789 & 1.84 \\
\hline R07,4 - Pain in chest, unspecified & 24,301 & 1.74 \\
\hline J39,9 - Disease of upper respiratory tract, unspecified & 22,087 & 1.58 \\
\hline R52,9 - Pain, unspecified & 22,071 & 1.58 \\
\hline M79,1 - Myalgia & 21,506 & 1.54 \\
\hline J00 - Acute nasopharyngitis [common cold] & 19,611 & 1.40 \\
\hline M54,5 - Low back pain & 18,097 & 1.29 \\
\hline R42 - Dizziness and giddiness & 16,534 & 1.18 \\
\hline R52,0 - Acute pain & 16,204 & 1.16 \\
\hline M79,9- Soft tissue disorder, unspecified & 15,249 & 1.09 \\
\hline J06,9 - Acute upper respiratory infection, unspecified & 15,108 & 1.08 \\
\hline M25,5 - Pain in joint & 14,678 & 1.05 \\
\hline R50 - Fever of other and unknown origin & 13,549 & 0.97 \\
\hline W84 - Unspecified threat to breathing & 13,187 & 0.94 \\
\hline $\begin{array}{l}\text { W51 - Accidental striking against or bumped into } \\
\text { by another person }\end{array}$ & 12,936 & 0.92 \\
\hline R07,3 - Other chest pain & 12,711 & 0.91 \\
\hline Y35 - Legal intervention & 12,686 & 0.91 \\
\hline R07,0 - Pain in throat & 9,807 & 0.70 \\
\hline N91 - Absent, scanty and rare menstruation & 9,774 & 0.70 \\
\hline N39,0 - Urinary tract infection, site not specified & 9,511 & 0.68 \\
\hline J20 - Acute bronchitis & 8,879 & 0.63 \\
\hline R55 - Syncope and collapse & 7,976 & 0.57 \\
\hline $\begin{array}{l}\text { K52,9- Noninfective gastroenteritis and colitis, } \\
\text { unspecified }\end{array}$ & 7,806 & 0.56 \\
\hline H57,1 - Ocular pain & 7,403 & 0.53 \\
\hline T78,4 - Other and unspecified allergy & 7,208 & 0.52 \\
\hline O26,9 - Pregnancy related conditions, unspecified & 6,755 & 0.48 \\
\hline S93,4 - Sprain of ankle & 6,479 & 0.46 \\
\hline N23 - Unspecified renal colic & 6,200 & 0.44 \\
\hline Other diagnoses & 315,261 & 22.53 \\
\hline
\end{tabular}

Table 38. Number and Distribution of 40 Leading Diagnosis for Emergency Department Visits (\%), BKHB Secondary Care Hospitals 2014

\begin{tabular}{|c|c|c|}
\hline ICD-10 Diagnosis Code & $\begin{array}{l}\text { Number of } \\
\text { Diagnosis }\end{array}$ & $\%$ \\
\hline J06,9- Acute upper respiratory infection, unspecified & 105,886 & 12.68 \\
\hline J02 - Acute pharyngitis & 67,076 & 8.04 \\
\hline R10,4 - Other and unspecified abdominal pain & 29,208 & 3.50 \\
\hline J02,9 - Acute pharyngitis, unspecified & 28,403 & 3.40 \\
\hline $\begin{array}{l}\text { Z00,0 - Encounter for general adult medical } \\
\text { examination }\end{array}$ & 27,461 & 3.29 \\
\hline R51 - Headache & 26,907 & 3.22 \\
\hline M79,1 - Myalgia & 25,330 & 3.03 \\
\hline R11 - Nausea and vomiting & 24,316 & 2.91 \\
\hline R07,4 - Pain in chest, unspecified & 17,321 & 2.08 \\
\hline B87,1 - Wound myiasis & 17,180 & 2.06 \\
\hline I10-Essential (primary) hypertension & 17,029 & 2.04 \\
\hline J00 - Acute nasopharyngitis [common cold] & 16,271 & 1.95 \\
\hline W19- Unspecified fall & 15,913 & 1.91 \\
\hline J03 - Acute tonsillitis & 15,343 & 1.84 \\
\hline M54,5 - Low back pain & 12,404 & 1.49 \\
\hline R42 - Dizziness and giddiness & 11,567 & 1.39 \\
\hline J03,9-Acute tonsillitis, unspecified & 11,411 & 1.37 \\
\hline $\mathrm{N} 39,0$ - Urinary tract infection, site not specified & 10,748 & 1.29 \\
\hline M79,8- Other specified soft tissue disorders & 10,041 & 1.20 \\
\hline $\begin{array}{l}\text { J06 - Acute upper respiratory infections of multiple } \\
\text { and unspecified sites }\end{array}$ & 9,328 & 1.12 \\
\hline J18,9- Pneumonia, unspecified organism & 9,086 & 1.09 \\
\hline K30 - Functional dyspepsia & 8,416 & 1.01 \\
\hline N30,0 - Acute cystitis & 8,159 & 0.98 \\
\hline $\begin{array}{l}\text { M79,98 - Soft tissue disorder, unspecified, Other } \\
\text { diagnoses }\end{array}$ & 8,142 & 0.98 \\
\hline A09-Infectious gastroenteritis and colitis, unspecified & 7,814 & 0.94 \\
\hline J20,9 - Acute bronchitis, tanımlanmamış & 7,353 & 0.88 \\
\hline R52,0 - Acute pain & 7,323 & 0.88 \\
\hline R06,0-Dispne & 6,843 & 0.82 \\
\hline $\begin{array}{l}\text { M79,99 - Soft tissue disorder, unspecified, yer } \\
\text { tanımlanmamış }\end{array}$ & 6,813 & 0.82 \\
\hline $\begin{array}{l}\text { W01 - Fall on same level from slipping, tripping and } \\
\text { stumbling }\end{array}$ & 6,634 & 0.79 \\
\hline J20 - Acute bronchitis & 6,626 & 0.79 \\
\hline N23 - Unspecified renal colic & 5,986 & 0.72 \\
\hline F41,9-Anxiety disorder, unspecified & 5,923 & 0.71 \\
\hline Z00,8 - Encounter for other general examination & 5,796 & 0.69 \\
\hline T78,4 - Other and unspecified allergy & 5,641 & 0.68 \\
\hline A08,4 - Viral intestinal infection, unspecified & 5,185 & 0.62 \\
\hline A04,9-Bacterial intestinal infection, unspecified & 5,179 & 0.62 \\
\hline L50,9- Urticaria, unspecified & 5,177 & 0.62 \\
\hline J45,9- Other and unspecified asthma & 4,584 & 0.55 \\
\hline M79,18 - Myalgia, Other & 4,496 & 0.54 \\
\hline Other diagnoses & 204,422 & 24.49 \\
\hline
\end{tabular}


Table 39. Number and Distribution of 20 Leading Diagnosis for Emergency Department Visits by Age and Gender (\%), BKHB 2014

\begin{tabular}{|c|c|c|c|}
\hline Age / Gender & ICD-10 Diagnosis Code & $\begin{array}{l}\text { Number of } \\
\text { Diagnosis }\end{array}$ & $\%$ \\
\hline \multicolumn{2}{|c|}{ 0-12 months / Female } & 13,813 & 100.00 \\
\hline \multicolumn{2}{|c|}{$\begin{array}{l}\text { J06-Acute upper respiratory infections of } \\
\text { multiple and unspecified sites }\end{array}$} & 1,784 & 12.92 \\
\hline \multicolumn{2}{|c|}{$\begin{array}{l}\text { P96,4 - Termination of pregnancy, affecting } \\
\text { fetus and newborn }\end{array}$} & 1,400 & 10.14 \\
\hline \multicolumn{2}{|c|}{ J03 - Acute tonsillitis } & 1,260 & 9.12 \\
\hline \multicolumn{2}{|c|}{ J00 - Acute nasopharyngitis [common cold] } & 581 & 4.21 \\
\hline \multicolumn{2}{|c|}{ R50 - Fever of other and unknown origin } & 554 & 4.01 \\
\hline \multicolumn{2}{|c|}{ P59,9 - Neonatal jaundice, unspecified } & 524 & 3.79 \\
\hline \multicolumn{2}{|c|}{ R11 - Nausea and vomiting } & 473 & 3.42 \\
\hline \multicolumn{2}{|c|}{ J02 - Acute pharyngitis } & 431 & 3.12 \\
\hline \multicolumn{2}{|c|}{ J39-Other diseases of upper respiratory tract } & 367 & 2.66 \\
\hline \multicolumn{2}{|c|}{ R10,4 - Other and unspecified abdominal pain } & 365 & 2.64 \\
\hline \multicolumn{2}{|c|}{ R05-Cough } & 338 & 2.45 \\
\hline \multicolumn{2}{|c|}{ K59,0-Constipation } & 278 & 2.01 \\
\hline \multicolumn{2}{|c|}{ R45,1 - Restlessness and agitation } & 276 & 2.00 \\
\hline \multicolumn{2}{|c|}{$\begin{array}{l}\text { J39,9-Disease of upper respiratory tract, } \\
\text { unspecified }\end{array}$} & 273 & 1.98 \\
\hline \multicolumn{2}{|c|}{$\begin{array}{l}\text { J06,9-Acute upper respiratory infection, } \\
\text { unspecified }\end{array}$} & 271 & 1.96 \\
\hline \multicolumn{2}{|c|}{ J20-Acute bronchitis } & 270 & 1.95 \\
\hline \multicolumn{2}{|c|}{$\begin{array}{l}\text { P96- Other conditions originating in the } \\
\text { perinatal period }\end{array}$} & 254 & 1.84 \\
\hline \multicolumn{2}{|c|}{$\begin{array}{l}\text { P59- Neonatal jaundice from other and } \\
\text { unspecified causes }\end{array}$} & 197 & 1.43 \\
\hline \multicolumn{2}{|c|}{ J21 - Acute bronchiolitis } & 193 & 1.40 \\
\hline \multicolumn{2}{|c|}{$\begin{array}{l}\text { W01 - Fall on same level from slipping, } \\
\text { tripping and stumbling }\end{array}$} & 179 & 1.30 \\
\hline \multicolumn{2}{|c|}{ Other diagnoses } & 3,545 & 25.66 \\
\hline \multicolumn{2}{|c|}{ 0-12 Months / Male } & 16,990 & 100.00 \\
\hline \multicolumn{2}{|c|}{$\begin{array}{l}\text { J06-Acute upper respiratory infections of } \\
\text { multiple and unspecified sites }\end{array}$} & 2,242 & 13.20 \\
\hline \multicolumn{2}{|c|}{ J03 - Acute tonsillitis } & 1,636 & 9.63 \\
\hline \multicolumn{2}{|c|}{$\begin{array}{l}\text { P96,4 - Termination of pregnancy, affecting } \\
\text { fetus and newborn }\end{array}$} & 1,454 & 8.56 \\
\hline \multicolumn{2}{|c|}{ J00 - Acute nasopharyngitis [common cold] } & 732 & 4.31 \\
\hline \multicolumn{2}{|c|}{ R50 - Fever of other and unknown origin } & 704 & 4.14 \\
\hline \multicolumn{2}{|c|}{ P59,9- Neonatal jaundice, unspecified } & 596 & 3.51 \\
\hline \multicolumn{2}{|c|}{ J02 - Acute pharyngitis } & 551 & 3.24 \\
\hline $\mathrm{R} 11$ & ea and vomiting & 500 & 2.94 \\
\hline R05 - & & 464 & 2.73 \\
\hline$J 20-$ & bronchitis & 432 & 2.54 \\
\hline
\end{tabular}

Table 39. Number and Distribution of 20 Leading Diagnosis for Emergency Department Visits by Age and Gender (\%), BKHB 2014 (continued)

\begin{tabular}{|c|c|c|c|}
\hline Age / Gender & ICD-10 Diagnosis Code & $\begin{array}{c}\text { Number of } \\
\text { Diagnosis }\end{array}$ & $\%$ \\
\hline \multicolumn{2}{|c|}{ 0-12 months / Female } & 13,813 & 100.00 \\
\hline \multicolumn{2}{|c|}{$\begin{array}{l}\text { J39-Other diseases of upper respiratory } \\
\text { tract }\end{array}$} & 432 & 2.54 \\
\hline \multicolumn{2}{|c|}{$\begin{array}{l}\text { R10,4 - Other and unspecified abdominal } \\
\text { pain }\end{array}$} & 406 & 2.39 \\
\hline \multicolumn{2}{|c|}{$\begin{array}{l}\text { J06,9-Acute upper respiratory infection, } \\
\text { unspecified }\end{array}$} & 385 & 2.27 \\
\hline \multicolumn{2}{|c|}{ J21 - Acute bronchiolitis } & 342 & 2.01 \\
\hline \multicolumn{2}{|c|}{ K59,0-Constipation } & 323 & 1.90 \\
\hline \multicolumn{2}{|c|}{ R45,1 - Restlessness and agitation } & 319 & 1.88 \\
\hline \multicolumn{2}{|c|}{$\begin{array}{l}\text { P96 - Other conditions originating in the } \\
\text { perinatal period }\end{array}$} & 310 & 1.82 \\
\hline \multicolumn{2}{|c|}{$\begin{array}{l}\text { J39,9-Disease of upper respiratory tract, } \\
\text { unspecified }\end{array}$} & 306 & 1.80 \\
\hline \multicolumn{2}{|c|}{$\begin{array}{l}\text { P59- Neonatal jaundice from other and } \\
\text { unspecified causes }\end{array}$} & 274 & 1.61 \\
\hline \multicolumn{2}{|c|}{$\begin{array}{l}\text { W01 - Fall on same level from slipping, } \\
\text { tripping and stumbling }\end{array}$} & 201 & 1.18 \\
\hline \multicolumn{2}{|c|}{ Other diagnoses } & 4,368 & 25.71 \\
\hline \multicolumn{2}{|c|}{ 1-4 Years / Female } & 88,400 & 100.00 \\
\hline \multicolumn{2}{|c|}{ J03 - Acute tonsillitis } & 14,006 & 15.84 \\
\hline \multicolumn{2}{|c|}{$\begin{array}{l}\text { J06 - Acute upper respiratory infections of } \\
\text { multiple and unspecified sites }\end{array}$} & 13,406 & 15.17 \\
\hline \multicolumn{2}{|c|}{ J00 - Acute nasopharyngitis [common cold] } & 5,492 & 6.21 \\
\hline \multicolumn{2}{|c|}{$\begin{array}{l}\text { J06,9-Acute upper respiratory infection, } \\
\text { unspecified }\end{array}$} & 4,575 & 5.18 \\
\hline \multicolumn{2}{|c|}{ J02 - Acute pharyngitis } & 4,470 & 5.06 \\
\hline \multicolumn{2}{|c|}{ R11 - Nausea and vomiting } & 3,241 & 3.67 \\
\hline \multicolumn{2}{|c|}{ J39- Other diseases of upper respiratory tract } & 2,875 & 3.25 \\
\hline \multicolumn{2}{|c|}{$\begin{array}{l}\text { W01 - Fall on same level from slipping, } \\
\text { tripping and stumbling }\end{array}$} & 2,279 & 2.58 \\
\hline \multicolumn{2}{|c|}{ R50 - Fever of other and unknown origin } & 2,187 & 2.47 \\
\hline \multicolumn{2}{|c|}{ J20 - Acute bronchitis } & 2,001 & 2.26 \\
\hline \multicolumn{2}{|c|}{ W19-Unspecified fall } & 1,979 & 2.24 \\
\hline \multicolumn{2}{|c|}{ R05-Cough } & 1,787 & 2.02 \\
\hline \multicolumn{2}{|c|}{$\begin{array}{l}\text { R10,4 - Other and unspecified abdominal } \\
\text { pain }\end{array}$} & 1,627 & 1.84 \\
\hline \multicolumn{2}{|c|}{$\begin{array}{l}\text { J39,9-Disease of upper respiratory tract, } \\
\text { unspecified }\end{array}$} & 1,592 & 1.80 \\
\hline \multicolumn{2}{|c|}{ J21 - Acute bronchiolitis } & 1,438 & 1.63 \\
\hline \multicolumn{2}{|c|}{ J18,9 - Pneumonia, unspecified organism } & 1,244 & 1.41 \\
\hline \multicolumn{2}{|c|}{$\begin{array}{l}\text { K52,9- Noninfective gastroenteritis and } \\
\text { colitis, unspecified }\end{array}$} & 1,122 & 1.27 \\
\hline \multicolumn{2}{|c|}{$\begin{array}{l}\text { A09-Infectious gastroenteritis and colitis, } \\
\text { unspecified }\end{array}$} & 1,081 & 1.22 \\
\hline $\begin{array}{l}\text { N39, } \\
\text { spec }\end{array}$ & ary tract infection, site not & 943 & 1.07 \\
\hline
\end{tabular}


Table 39. Number and Distribution of 20 Leading Diagnosis for Emergency Department Visits by Age and Gender (\%), BKHB 2014 (continued)

\begin{tabular}{|c|c|c|c|}
\hline Age / Gender & ICD-10 Diagnosis Code & $\begin{array}{l}\text { Number of } \\
\text { Diagnosis }\end{array}$ & $\%$ \\
\hline \multicolumn{2}{|c|}{ 1-4 Years / Male } & 111,989 & 100.00 \\
\hline \multicolumn{2}{|c|}{ J03-Acute tonsillitis } & 18,652 & 16.66 \\
\hline \multicolumn{2}{|c|}{$\begin{array}{l}\text { J06 - Acute upper respiratory infections of } \\
\text { multiple and unspecified sites }\end{array}$} & 16,760 & 14.97 \\
\hline \multicolumn{2}{|c|}{ J00 - Acute nasopharyngitis [common cold] } & 6,338 & 5.66 \\
\hline \multicolumn{2}{|c|}{$\begin{array}{l}\text { J06,9-Acute upper respiratory infection, } \\
\text { unspecified }\end{array}$} & 5,559 & 4.96 \\
\hline \multicolumn{2}{|c|}{ J02 - Acute pharyngitis } & 5,323 & 4.75 \\
\hline \multicolumn{2}{|c|}{ R11 - Nausea and vomiting } & 3,751 & 3.35 \\
\hline \multicolumn{2}{|c|}{ J39- Other diseases of upper respiratory tract } & 3,408 & 3.04 \\
\hline \multicolumn{2}{|c|}{$\begin{array}{l}\text { W01 - Fall on same level from slipping, } \\
\text { tripping and stumbling }\end{array}$} & 3,016 & 2.69 \\
\hline \multicolumn{2}{|c|}{ J20 - Acute bronchitis } & 2,975 & 2.66 \\
\hline \multicolumn{2}{|c|}{ W19-Unspecified fall } & 2,672 & 2.39 \\
\hline \multicolumn{2}{|c|}{ R50 - Fever of other and unknown origin } & 2,560 & 2.29 \\
\hline \multicolumn{2}{|c|}{ R05-Cough } & 2,484 & 2.22 \\
\hline \multicolumn{2}{|c|}{ J21 - Acute bronchiolitis } & 2,076 & 1.85 \\
\hline \multicolumn{2}{|c|}{ R10,4 - Other and unspecified abdominal pain } & 1,984 & 1.77 \\
\hline \multicolumn{2}{|c|}{$\begin{array}{l}\text { J39,9-Disease of upper respiratory tract, } \\
\text { unspecified }\end{array}$} & 1,870 & 1.67 \\
\hline \multicolumn{2}{|c|}{$\begin{array}{l}\text { A09-Infectious gastroenteritis and colitis, } \\
\text { unspecified }\end{array}$} & 1,471 & 1.31 \\
\hline \multicolumn{2}{|c|}{ J18,9-Pneumonia, unspecified organism } & 1,451 & 1.30 \\
\hline \multicolumn{2}{|c|}{$\begin{array}{l}\text { K52,9- Noninfective gastroenteritis and } \\
\text { colitis, unspecified }\end{array}$} & 1,445 & 1.29 \\
\hline \multicolumn{2}{|c|}{ T78,4 - Other and unspecified allergy } & 829 & 0.74 \\
\hline \multicolumn{2}{|c|}{$\begin{array}{l}\text { K52,8- Other specified noninfective } \\
\text { gastroenteritis and colitis }\end{array}$} & 809 & 0.72 \\
\hline \multicolumn{2}{|c|}{ Other diagnoses } & 26,556 & 23.71 \\
\hline \multicolumn{2}{|c|}{ 5-14 Years / Female } & 120,942 & 100.00 \\
\hline \multicolumn{2}{|c|}{ J03 - Acute tonsillitis } & 16,425 & 13.58 \\
\hline \multicolumn{2}{|c|}{$\begin{array}{l}\text { J06- Acute upper respiratory infections of } \\
\text { multiple and unspecified sites }\end{array}$} & 13,462 & 11.13 \\
\hline \multicolumn{2}{|c|}{$\begin{array}{l}\text { J06,9-Acute upper respiratory infection, } \\
\text { unspecified }\end{array}$} & 7,770 & 6.42 \\
\hline \multicolumn{2}{|c|}{ J02 - Acute pharyngitis } & 6,687 & 5.53 \\
\hline \multicolumn{2}{|c|}{$\begin{array}{l}\text { R10,4 - Other and unspecified abdominal } \\
\text { pain }\end{array}$} & 4,950 & 4.09 \\
\hline \multicolumn{2}{|c|}{ J00 - Acute nasopharyngitis [common cold] } & 4,794 & 3.96 \\
\hline \multicolumn{2}{|c|}{ R11 - Nausea and vomiting } & 4,727 & 3.91 \\
\hline $\begin{array}{l}\text { W01 } \\
\text { tripp }\end{array}$ & $\begin{array}{l}\text { n same level from slipping, } \\
\text { d stumbling }\end{array}$ & 3,930 & 3.25 \\
\hline $\begin{array}{l}\text { J39- } \\
\text { tract }\end{array}$ & diseases of upper respiratory & 3,207 & 2.65 \\
\hline W19 & ecified fall & 3,074 & 2.54 \\
\hline $\begin{array}{l}\text { N39, } \\
\text { speci }\end{array}$ & nary tract infection, site not & 2,204 & 1.82 \\
\hline
\end{tabular}

Table 39. Number and Distribution of 20 Leading Diagnosis for Emergency Department Visits by Age and Gender (\%), BKHB 2014 (continued)

\begin{tabular}{|c|c|c|c|}
\hline Age / Gender & ICD-10 Diagnosis Code & $\begin{array}{l}\text { Number of } \\
\text { Diagnosis }\end{array}$ & $\%$ \\
\hline \multicolumn{2}{|c|}{ J18,9-Pneumonia, unspecified organism } & 2,082 & 1.72 \\
\hline \multicolumn{2}{|c|}{ R50 - Fever of other and unknown origin } & 1,935 & 1.60 \\
\hline \multicolumn{2}{|c|}{$\begin{array}{l}\text { J39,9- Disease of upper respiratory tract, } \\
\text { unspecified }\end{array}$} & 1,522 & 1.26 \\
\hline \multicolumn{2}{|c|}{ R05-Cough } & 1,407 & 1.16 \\
\hline \multicolumn{2}{|c|}{ J20 - Acute bronchitis } & 1,371 & 1.13 \\
\hline \multicolumn{2}{|c|}{ J03,9-Acute tonsillitis, unspecified } & 1,222 & 1.01 \\
\hline \multicolumn{2}{|c|}{ H66,9-Otitis media, unspecified } & 1,200 & 0.99 \\
\hline \multicolumn{2}{|c|}{ J02,9-Acute pharyngitis, unspecified } & 1,194 & 0.99 \\
\hline \multicolumn{2}{|c|}{$\begin{array}{l}\text { K52,9- Noninfective gastroenteritis and } \\
\text { colitis, unspecified }\end{array}$} & 1,158 & 0.96 \\
\hline \multicolumn{2}{|c|}{ Other diagnoses } & 36,621 & 30.28 \\
\hline \multicolumn{2}{|c|}{ 5-14 Years / Male } & 120,942 & 100.00 \\
\hline \multicolumn{2}{|c|}{ J03 - Acute tonsillitis } & 19,079 & 12.91 \\
\hline \multicolumn{2}{|c|}{$\begin{array}{l}\text { J06 - Acute upper respiratory infections of } \\
\text { multiple and unspecified sites }\end{array}$} & 15,794 & 10.69 \\
\hline \multicolumn{2}{|c|}{$\begin{array}{l}\text { J06,9- Acute upper respiratory infection, } \\
\text { unspecified }\end{array}$} & 8,762 & 5.93 \\
\hline \multicolumn{2}{|c|}{ J02-Acute pharyngitis } & 7,385 & 5.00 \\
\hline \multicolumn{2}{|c|}{$\begin{array}{l}\text { W01 - Fall on same level from slipping, } \\
\text { tripping and stumbling }\end{array}$} & 6,948 & 4.70 \\
\hline \multicolumn{2}{|c|}{ W19-Unspecified fall } & 5,950 & 4.03 \\
\hline \multicolumn{2}{|c|}{ J00 - Acute nasopharyngitis [common cold] } & 5,332 & 3.61 \\
\hline \multicolumn{2}{|c|}{ R11 - Nausea and vomiting } & 4,907 & 3.32 \\
\hline \multicolumn{2}{|c|}{$\begin{array}{l}\text { R10,4- Other and unspecified abdominal } \\
\text { pain }\end{array}$} & 4,802 & 3.25 \\
\hline \multicolumn{2}{|c|}{$\begin{array}{l}\text { J39- Other diseases of upper respiratory } \\
\text { tract }\end{array}$} & 3,625 & 2.45 \\
\hline \multicolumn{2}{|c|}{ J18,9-Pneumonia, unspecified organism } & 2,117 & 1.43 \\
\hline \multicolumn{2}{|c|}{ R50 - Fever of other and unknown origin } & 2,025 & 1.37 \\
\hline \multicolumn{2}{|c|}{ J20 - Acute bronchitis } & 1,976 & 1.34 \\
\hline \multicolumn{2}{|c|}{ M79,9-Soft tissue disorder, unspecified } & 1,748 & 1.18 \\
\hline \multicolumn{2}{|c|}{ R05-Cough } & 1,720 & 1.16 \\
\hline \multicolumn{2}{|c|}{$\begin{array}{l}\text { J39,9-Disease of upper respiratory tract, } \\
\text { unspecified }\end{array}$} & 1,670 & 1.13 \\
\hline \multicolumn{2}{|c|}{$\begin{array}{l}\text { A09-Infectious gastroenteritis and colitis, } \\
\text { unspecified }\end{array}$} & 1,347 & 0.91 \\
\hline \multicolumn{2}{|c|}{ J03,9-Acute tonsillitis, unspecified } & 1,342 & 0.91 \\
\hline $\mathrm{J} 02,9$ & e pharyngitis, unspecified & 1,342 & 0.91 \\
\hline $\mathrm{T} 78,4$ & er and unspecified allergy & 1,303 & 0.88 \\
\hline Othe & noses & 48,607 & 32.89 \\
\hline 15-24 Years / F & & 199,283 & 100.00 \\
\hline $\begin{array}{l}\mathrm{J} 06,9 \\
\text { unsp }\end{array}$ & e upper respiratory infection, & 11,536 & 5.90 \\
\hline $\mathrm{R} 52-$ & unspecified & 9,321 & 4.77 \\
\hline
\end{tabular}


Table 39. Number and Distribution of 20 Leading Diagnosis for Emergency Department Visits by Age and Gender (\%), BKHB 2014 (continued)

\begin{tabular}{|c|c|c|c|}
\hline Age / Gender & ICD-10 Diagnosis Code & $\begin{array}{l}\text { Number of } \\
\text { Diagnosis }\end{array}$ & $\%$ \\
\hline \multicolumn{2}{|c|}{ J02 - Acute pharyngitis } & 9,314 & 4.76 \\
\hline \multicolumn{2}{|c|}{$\begin{array}{l}\text { R10,4 - Other and unspecified abdominal } \\
\text { pain }\end{array}$} & 7,815 & 4.00 \\
\hline \multicolumn{2}{|c|}{ J03-Acute tonsillitis } & 7,323 & 3.75 \\
\hline \multicolumn{2}{|c|}{$\begin{array}{l}\text { W01 - Fall on same level from slipping, } \\
\text { tripping and stumbling }\end{array}$} & 6,991 & 3.58 \\
\hline \multicolumn{2}{|c|}{$\begin{array}{l}\text { Z00,0- Encounter for general adult medical } \\
\text { examination }\end{array}$} & 6,822 & 3.49 \\
\hline \multicolumn{2}{|c|}{ R11 - Nausea and vomiting } & 6,818 & 3.49 \\
\hline \multicolumn{2}{|c|}{ W19-Unspecified fall } & 5,357 & 2.74 \\
\hline \multicolumn{2}{|c|}{ R53 - Malaise and fatigue } & 5,331 & 2.73 \\
\hline \multicolumn{2}{|c|}{$\begin{array}{l}\text { J06-Acute upper respiratory infections of } \\
\text { multiple and unspecified sites }\end{array}$} & 4,767 & 2.44 \\
\hline \multicolumn{2}{|c|}{ M79,1 - Myalgia } & 4,290 & 2.19 \\
\hline \multicolumn{2}{|c|}{$\begin{array}{l}\text { W51 - Accidental striking against or bumped } \\
\text { into by another person }\end{array}$} & 3,989 & 2.04 \\
\hline \multicolumn{2}{|c|}{ R51 - Headache } & 3,954 & 2.02 \\
\hline \multicolumn{2}{|c|}{ R10-Abdominal and pelvic pain } & 2,926 & 1.50 \\
\hline \multicolumn{2}{|c|}{ R05-Cough } & 2,917 & 1.49 \\
\hline \multicolumn{2}{|c|}{ J02,9-Acute pharyngitis, unspecified } & 2,861 & 1.46 \\
\hline \multicolumn{2}{|c|}{ J39-Other diseases of upper respiratory tract } & 2,770 & 1.42 \\
\hline \multicolumn{2}{|c|}{ M54,5 - Low back pain } & 2,635 & 1.35 \\
\hline \multicolumn{2}{|c|}{ R07,4 - Pain in chest, unspecified } & 2,470 & 1.26 \\
\hline \multicolumn{2}{|c|}{ Other diagnoses } & 85,038 & 42.67 \\
\hline \multicolumn{2}{|c|}{ 15-24 Years / Male } & 195,538 & 100.00 \\
\hline \multicolumn{2}{|c|}{$\begin{array}{l}\text { J06,9-Acute upper respiratory infection, } \\
\text { unspecified }\end{array}$} & 11,536 & 5.90 \\
\hline \multicolumn{2}{|c|}{ R52 - Pain, unspecified } & 9,321 & 4.77 \\
\hline \multicolumn{2}{|c|}{ J02 - Acute pharyngitis } & 9,314 & 4.76 \\
\hline \multicolumn{2}{|c|}{$\begin{array}{l}\text { R10,4 - Other and unspecified abdominal } \\
\text { pain }\end{array}$} & 7,815 & 4.00 \\
\hline \multicolumn{2}{|c|}{ J03 - Acute tonsillitis } & 7,323 & 3.75 \\
\hline \multicolumn{2}{|c|}{$\begin{array}{l}\text { W01 - Fall on same level from slipping, } \\
\text { tripping and stumbling }\end{array}$} & 6,991 & 3.58 \\
\hline \multicolumn{2}{|c|}{$\begin{array}{l}\text { Z00,0 - Encounter for general adult medical } \\
\text { examination }\end{array}$} & 6,822 & 3.49 \\
\hline \multicolumn{2}{|c|}{ R11 - Nausea and vomiting } & 6,818 & 3.49 \\
\hline \multicolumn{2}{|c|}{ W19-Unspecified fall } & 5,357 & 2.74 \\
\hline R53 - & ise and fatigue & 5,331 & 2.73 \\
\hline $\begin{array}{l}\text { J06- } \\
\text { multi }\end{array}$ & $\begin{array}{l}\text { upper respiratory infections of } \\
\text { hd unspecified sites }\end{array}$ & 4,767 & 2.44 \\
\hline M79, & algia & 4,290 & 2.19 \\
\hline $\begin{array}{l}\text { W51 } \\
\text { into }\end{array}$ & $\begin{array}{l}\text { lental striking against or bumped } \\
\text { ther person }\end{array}$ & 3,989 & 2.04 \\
\hline R51 - & lache & 3,954 & 2.02 \\
\hline R10- & minal and pelvic pain & 2,926 & 1.50 \\
\hline
\end{tabular}

Table 39. Number and Distribution of 20 Leading Diagnosis for Emergency Department Visits by Age and Gender (\%), BKHB 2014 (continued)

\begin{tabular}{|c|c|c|c|}
\hline Age / Gender & ICD-10 Diagnosis Code & $\begin{array}{l}\text { Number of } \\
\text { Diagnosis }\end{array}$ & $\%$ \\
\hline \multicolumn{2}{|c|}{ R05-Cough } & 2,917 & 1.49 \\
\hline \multicolumn{2}{|c|}{ J02,9- Acute pharyngitis, unspecified } & 2,861 & 1.46 \\
\hline \multicolumn{2}{|c|}{$\begin{array}{l}\text { J39-Other diseases of upper respiratory } \\
\text { tract }\end{array}$} & 2,770 & 1.42 \\
\hline \multicolumn{2}{|c|}{ M54,5 - Low back pain } & 2,635 & 1.35 \\
\hline \multicolumn{2}{|c|}{ R07,4 - Pain in chest, unspecified } & 2,470 & 1.26 \\
\hline \multicolumn{2}{|c|}{ Other diagnoses } & 85,331 & 43.64 \\
\hline \multicolumn{2}{|c|}{ 25-44 Years / Female } & 398,572 & 100.00 \\
\hline \multicolumn{2}{|c|}{$\begin{array}{l}\text { R10,4- Other and unspecified abdominal } \\
\text { pain }\end{array}$} & 24,499 & 6.15 \\
\hline \multicolumn{2}{|c|}{$\begin{array}{l}\text { J06,9-Acute upper respiratory infection, } \\
\text { unspecified }\end{array}$} & 22,005 & 5.52 \\
\hline \multicolumn{2}{|c|}{ R52-Pain, unspecified } & 21,132 & 5.30 \\
\hline \multicolumn{2}{|c|}{ R11 - Nausea and vomiting } & 19,250 & 4.83 \\
\hline \multicolumn{2}{|c|}{ J02 - Acute pharyngitis } & 19,092 & 4.79 \\
\hline \multicolumn{2}{|c|}{ J03-Acute tonsillitis } & 15,442 & 3.87 \\
\hline \multicolumn{2}{|c|}{ R51 - Headache } & 15,035 & 3.77 \\
\hline \multicolumn{2}{|c|}{ R53 - Malaise and fatigue } & 12,852 & 3.22 \\
\hline \multicolumn{2}{|c|}{ M79,1 - Myalgia } & 10,466 & 2.63 \\
\hline \multicolumn{2}{|c|}{ R10-Abdominal and pelvic pain } & 8,890 & 2.23 \\
\hline \multicolumn{2}{|c|}{$\begin{array}{l}\text { J06-Acute upper respiratory infections of } \\
\text { multiple and unspecified sites }\end{array}$} & 7,110 & 1.78 \\
\hline \multicolumn{2}{|c|}{ M54,5 - Low back pain } & 6,648 & 1.67 \\
\hline \multicolumn{2}{|c|}{ R42 - Dizziness and giddiness } & 6,586 & 1.65 \\
\hline \multicolumn{2}{|c|}{ N91 - Absent, scanty and rare menstruation } & 6,296 & 1.58 \\
\hline \multicolumn{2}{|c|}{ R05-Cough } & 6,046 & 1.52 \\
\hline \multicolumn{2}{|c|}{ J02,9-Acute pharyngitis, unspecified } & 5,743 & 1.44 \\
\hline \multicolumn{2}{|c|}{ R07,4 - Pain in chest, unspecified } & 5,650 & 1.42 \\
\hline \multicolumn{2}{|c|}{ R52,0 - Acute pain } & 5,550 & 1.39 \\
\hline \multicolumn{2}{|c|}{ R52,9-Pain, unspecified } & 5,489 & 1.38 \\
\hline \multicolumn{2}{|c|}{$\begin{array}{l}\text { W01 - Fall on same level from slipping, } \\
\text { tripping and stumbling }\end{array}$} & 5,485 & 1.38 \\
\hline \multicolumn{2}{|c|}{ Other diagnoses } & 169,306 & 42.48 \\
\hline 25-44 Years / $\mathrm{N}$ & & 375501 & 100.00 \\
\hline $\begin{array}{l}\mathrm{J} 06,9 \\
\text { unsp }\end{array}$ & e upper respiratory infection, & 22,492 & 5.99 \\
\hline R52- & unspecified & 19,920 & 5.30 \\
\hline J02- & pharyngitis & 18,000 & 4.79 \\
\hline $\mathrm{R} 10,4$ & r and unspecified abdominal pain & 15,391 & 4.10 \\
\hline J03- & tonsillitis & 14,770 & 3.93 \\
\hline R11- & ea and vomiting & 12,502 & 3.33 \\
\hline M79, & algia & 12,242 & 3.26 \\
\hline R53- & se and fatigue & 12,194 & 3.25 \\
\hline $\begin{array}{l}Z 00,0 \\
\text { exam }\end{array}$ & $\begin{array}{l}\text { unter for general adult medical } \\
\text { n }\end{array}$ & 9,517 & 2.53 \\
\hline
\end{tabular}


Table 39. Number and Distribution of 20 Leading Diagnosis for Emergency Department Visits by Age and Gender (\%), BKHB 2014 (continued)

\begin{tabular}{|c|c|c|c|}
\hline Age / Gender & ICD-10 Diagnosis Code & $\begin{array}{l}\text { Number of } \\
\text { Diagnosis }\end{array}$ & $\%$ \\
\hline \multicolumn{2}{|c|}{ M54,5 - Low back pain } & 9,264 & 2.47 \\
\hline \multicolumn{2}{|c|}{ R51 - Headache } & 9,137 & 2.43 \\
\hline \multicolumn{2}{|c|}{$\begin{array}{l}\text { W01 - Fall on same level from slipping, } \\
\text { tripping and stumbling }\end{array}$} & 8,772 & 2.34 \\
\hline \multicolumn{2}{|c|}{ R07,4 - Pain in chest, unspecified } & 8,094 & 2.16 \\
\hline \multicolumn{2}{|c|}{$\begin{array}{l}\text { J06-Acute upper respiratory infections of } \\
\text { multiple and unspecified sites }\end{array}$} & 7,476 & 1.99 \\
\hline \multicolumn{2}{|c|}{ W19-Unspecified fall } & 6,529 & 1.74 \\
\hline \multicolumn{2}{|c|}{ R10 - Abdominal and pelvic pain } & 6,120 & 1.63 \\
\hline \multicolumn{2}{|c|}{ R05-Cough } & 6,008 & 1.60 \\
\hline \multicolumn{2}{|c|}{$\begin{array}{l}\text { W51 - Accidental striking against or bumped } \\
\text { into by another person }\end{array}$} & 5,999 & 1.60 \\
\hline \multicolumn{2}{|c|}{ J02,9-Acute pharyngitis, unspecified } & 5,870 & 1.56 \\
\hline \multicolumn{2}{|c|}{ Y35 - Legal intervention } & 5,241 & 1.40 \\
\hline \multicolumn{2}{|c|}{ Other diagnoses } & 159,963 & 42.60 \\
\hline \multicolumn{2}{|c|}{ 45-64 Years / Female } & 217,205 & 100.00 \\
\hline \multicolumn{2}{|c|}{ R52-Pain, unspecified } & 11,991 & 5.52 \\
\hline \multicolumn{2}{|c|}{$\begin{array}{l}\text { J06.9-Acute upper respiratory infection. } \\
\text { unspecified }\end{array}$} & 11.278 & 5.19 \\
\hline \multicolumn{2}{|c|}{ J02 - Acute pharyngitis } & 9.756 & 4.49 \\
\hline \multicolumn{2}{|c|}{$\begin{array}{l}\text { R10.4- Other and unspecified abdominal } \\
\text { pain }\end{array}$} & 9.628 & 4.43 \\
\hline \multicolumn{2}{|c|}{ R11 - Nausea and vomiting } & 9.620 & 4.43 \\
\hline \multicolumn{2}{|c|}{ R51 - Headache } & 9.373 & 4.32 \\
\hline \multicolumn{2}{|c|}{ J03 - Acute tonsillitis } & 7.976 & 3.67 \\
\hline \multicolumn{2}{|c|}{ R53 - Malaise and fatigue } & 7.647 & 3.52 \\
\hline \multicolumn{2}{|c|}{ M79.1 - Myalgia } & 6.936 & 3.19 \\
\hline \multicolumn{2}{|c|}{ R07.4-Pain in chest. unspecified } & 6.654 & 3.06 \\
\hline \multicolumn{2}{|c|}{ I10-Essential (primary) hypertension } & 6.158 & 2.84 \\
\hline \multicolumn{2}{|c|}{ R42 - Dizziness and giddiness } & 5.058 & 2.33 \\
\hline \multicolumn{2}{|c|}{ M54.5 - Low back pain } & 4.322 & 1.99 \\
\hline \multicolumn{2}{|c|}{$\begin{array}{l}\text { W01 - Fall on same level from slipping. } \\
\text { tripping and stumbling }\end{array}$} & 4.083 & 1.88 \\
\hline \multicolumn{2}{|c|}{ R10- Abdominal and pelvic pain } & 3.749 & 1.73 \\
\hline R05 - & & 3.684 & 1.70 \\
\hline J02.9 & te pharyngitis. unspecified & 3.608 & 1.66 \\
\hline $\begin{array}{l}\text { J06- } \\
\text { multi }\end{array}$ & $\begin{array}{l}\text { upper respiratory infections of } \\
\text { ad unspecified sites }\end{array}$ & 3.526 & 1.62 \\
\hline W19 & secified fall & 3.397 & 1.56 \\
\hline R52.0 & te pain & 2.932 & 1.35 \\
\hline Othe & noses & 85.829 & 39.52 \\
\hline 45-64 Years / $M$ & & 172.560 & 100.00 \\
\hline R52- & unspecified & 9.813 & 5.69 \\
\hline $\begin{array}{l}\text { J06.9 } \\
\text { unsp }\end{array}$ & $\begin{array}{l}\text { te upper respiratory infection. } \\
d\end{array}$ & 8.221 & 4.76 \\
\hline
\end{tabular}

Table 39. Number and Distribution of 20 Leading Diagnosis for Emergency Department Visits by Age and Gender (\%), BKHB 2014 (continued)

\begin{tabular}{|c|c|c|c|}
\hline Age / Gender & ICD-10 Diagnosis Code & $\begin{array}{l}\text { Number of } \\
\text { Diagnosis }\end{array}$ & $\%$ \\
\hline \multicolumn{2}{|c|}{ R07.4 - Pain in chest. unspecified } & 7.301 & 4.23 \\
\hline \multicolumn{2}{|c|}{$\begin{array}{l}\text { R10.4 - Other and unspecified abdominal } \\
\text { pain }\end{array}$} & 6.927 & 4.01 \\
\hline \multicolumn{2}{|c|}{ J02 - Acute pharyngitis } & 6.757 & 3.92 \\
\hline \multicolumn{2}{|c|}{ R53 - Malaise and fatigue } & 5.823 & 3.37 \\
\hline \multicolumn{2}{|c|}{ R11 - Nausea and vomiting } & 5.742 & 3.33 \\
\hline \multicolumn{2}{|c|}{ J03-Acute tonsillitis } & 5.331 & 3.09 \\
\hline \multicolumn{2}{|c|}{ M79.1 - Myalgia } & 5.187 & 3.01 \\
\hline \multicolumn{2}{|c|}{ R51 - Headache } & 4.444 & 2.58 \\
\hline \multicolumn{2}{|c|}{ I10-Essential (primary) hypertension } & 3.930 & 2.28 \\
\hline \multicolumn{2}{|c|}{ M54.5 - Low back pain } & 3.810 & 2.21 \\
\hline \multicolumn{2}{|c|}{$\begin{array}{l}\text { W01 - Fall on same level from slipping. } \\
\text { tripping and stumbling }\end{array}$} & 3.176 & 1.84 \\
\hline \multicolumn{2}{|c|}{ R42 - Dizziness and giddiness } & 3.065 & 1.78 \\
\hline \multicolumn{2}{|c|}{ R10 - Abdominal and pelvic pain } & 3.005 & 1.74 \\
\hline \multicolumn{2}{|c|}{$\begin{array}{l}\text { Z00.0 - Encounter for general adult medical } \\
\text { examination }\end{array}$} & 2.884 & 1.67 \\
\hline \multicolumn{2}{|c|}{$\begin{array}{l}\text { J06- Acute upper respiratory infections of } \\
\text { multiple and unspecified sites }\end{array}$} & 2.881 & 1.67 \\
\hline \multicolumn{2}{|c|}{ W19-Unspecified fall } & 2.783 & 1.61 \\
\hline \multicolumn{2}{|c|}{ R05 - Cough } & 2.662 & 1.54 \\
\hline \multicolumn{2}{|c|}{ J02.9 - Acute pharyngitis. unspecified } & 2.613 & 1.51 \\
\hline \multicolumn{2}{|c|}{ Other diagnoses } & 76.205 & 44.16 \\
\hline \multicolumn{2}{|c|}{ 65-74 Years / Female } & 54.450 & 100.00 \\
\hline \multicolumn{2}{|c|}{ I10 - Essential (primary) hypertension } & 2.913 & 5.35 \\
\hline \multicolumn{2}{|c|}{ R52-Pain. unspecified } & 2.872 & 5.27 \\
\hline \multicolumn{2}{|c|}{ R11 - Nausea and vomiting } & 2.663 & 4.89 \\
\hline \multicolumn{2}{|c|}{ R07.4 - Pain in chest. unspecified } & 2.468 & 4.53 \\
\hline \multicolumn{2}{|c|}{$\begin{array}{l}\text { R10.4- Other and unspecified abdominal } \\
\text { pain }\end{array}$} & 2.400 & 4.41 \\
\hline \multicolumn{2}{|c|}{$\begin{array}{l}\text { J06.9-Acute upper respiratory infection. } \\
\text { unspecified }\end{array}$} & 2.311 & 4.24 \\
\hline \multicolumn{2}{|c|}{ R53 - Malaise and fatigue } & 1.978 & 3.63 \\
\hline J02- & pharyngitis & 1.805 & 3.31 \\
\hline & tonsillitis & 1.552 & 2.85 \\
\hline R51 - & dache & 1.432 & 2.63 \\
\hline R42- & ness and giddiness & 1.409 & 2.59 \\
\hline M79. & yalgia & 1.265 & 2.32 \\
\hline W84 & pecified threat to breathing & 1.074 & 1.97 \\
\hline $\begin{array}{l}\text { W01 } \\
\text { tripp }\end{array}$ & $\begin{array}{l}\text { on same level from slipping. } \\
\text { nd stumbling }\end{array}$ & 1.063 & 1.95 \\
\hline W19 & pecified fall & 1.021 & 1.88 \\
\hline R10- & ominal and pelvic pain & 849 & 1.56 \\
\hline R05 - & & 844 & 1.55 \\
\hline J02.9 & te pharyngitis. unspecified & 842 & 1.55 \\
\hline M54. & w back pain & 700 & 1.29 \\
\hline
\end{tabular}


Table 39. Number and Distribution of 20 Leading Diagnosis for Emergency Department Visits by Age and Gender (\%), BKHB 2014 (continued)

\begin{tabular}{|c|c|c|c|}
\hline Age / Gender & ICD-10 Diagnosis Code & $\begin{array}{l}\text { Number of } \\
\text { Diagnosis }\end{array}$ & $\%$ \\
\hline \multicolumn{2}{|c|}{ R52.9-Pain. unspecified } & 678 & 1.25 \\
\hline \multicolumn{2}{|c|}{ Other diagnoses } & 22.311 & 40.98 \\
\hline \multicolumn{2}{|c|}{ 65-74 Years / Male } & 42.058 & 100.00 \\
\hline \multicolumn{2}{|c|}{ R52-Pain. unspecified } & 2.267 & 5.39 \\
\hline \multicolumn{2}{|c|}{ R07.4- Pain in chest. unspecified } & 2.220 & 5.28 \\
\hline \multicolumn{2}{|c|}{ I10-Essential (primary) hypertension } & 1.794 & 4.27 \\
\hline \multicolumn{2}{|c|}{$\begin{array}{l}\text { R10.4 - Other and unspecified abdominal } \\
\text { pain }\end{array}$} & 1.765 & 4.20 \\
\hline \multicolumn{2}{|c|}{$\begin{array}{l}\text { J06.9- Acute upper respiratory infection. } \\
\text { unspecified }\end{array}$} & 1.627 & 3.87 \\
\hline \multicolumn{2}{|c|}{ R11 - Nausea and vomiting } & 1.586 & 3.77 \\
\hline \multicolumn{2}{|c|}{ R53 - Malaise and fatigue } & 1.419 & 3.37 \\
\hline \multicolumn{2}{|c|}{ W84 - Unspecified threat to breathing } & 1.310 & 3.11 \\
\hline \multicolumn{2}{|c|}{ J02 - Acute pharyngitis } & 1.193 & 2.84 \\
\hline \multicolumn{2}{|c|}{ J03-Acute tonsillitis } & 1.072 & 2.55 \\
\hline \multicolumn{2}{|c|}{ R42 - Dizziness and giddiness } & 920 & 2.19 \\
\hline \multicolumn{2}{|c|}{ R51 - Headache } & 839 & 1.99 \\
\hline \multicolumn{2}{|c|}{ M79.1 - Myalgia } & 785 & 1.87 \\
\hline \multicolumn{2}{|c|}{ R10-Abdominal and pelvic pain } & 720 & 1.71 \\
\hline \multicolumn{2}{|c|}{ R06.0-Dispne } & 705 & 1.68 \\
\hline \multicolumn{2}{|c|}{ R05-Cough } & 617 & 1.47 \\
\hline \multicolumn{2}{|c|}{ R07.3-Other chest pain } & 603 & 1.43 \\
\hline \multicolumn{2}{|c|}{$\begin{array}{l}\text { W01 - Fall on same level from slipping. } \\
\text { tripping and stumbling }\end{array}$} & 586 & 1.39 \\
\hline \multicolumn{2}{|c|}{ W19-Unspecified fall } & 579 & 1.38 \\
\hline \multicolumn{2}{|c|}{ W83 - Other specified threats to breathing } & 563 & 1.34 \\
\hline \multicolumn{2}{|c|}{ Other diagnoses } & 18.888 & 44.91 \\
\hline \multicolumn{2}{|c|}{ 75+ Years / Female } & 45.669 & 100.00 \\
\hline \multicolumn{2}{|c|}{ I10 - Essential (primary) hypertension } & 2.675 & 5.86 \\
\hline \multicolumn{2}{|c|}{ R07.4- Pain in chest. unspecified } & 2.531 & 5.54 \\
\hline $\mathrm{R} 11-$ & ea and vomiting & 2.298 & 5.03 \\
\hline R52- & unspecified & 2.162 & 4.73 \\
\hline $\begin{array}{l}\mathrm{R} 10.4 \\
\text { pain }\end{array}$ & er and unspecified abdominal & .142 & 4.69 \\
\hline $\begin{array}{l}\text { J06.9 } \\
\text { unsp }\end{array}$ & e upper respiratory infection. & 1.463 & 3.20 \\
\hline W84 & ecified threat to breathing & 1.414 & 3.10 \\
\hline R53 - & se and fatigue & 1.366 & 2.99 \\
\hline W19 & ecified fall & 1.250 & 2.74 \\
\hline R42- & ess and giddiness & 1.150 & 2.52 \\
\hline $\begin{array}{l}\text { W01 } \\
\text { tripp }\end{array}$ & $\begin{array}{l}\text { in same level from slipping. } \\
\text { d stumbling }\end{array}$ & 1.110 & 2.43 \\
\hline R51 - & ache & 969 & 2.12 \\
\hline J02- & pharyngitis & 939 & 2.06 \\
\hline M79. & algia & 778 & 1.70 \\
\hline
\end{tabular}

Table 39. Number and Distribution of 20 Leading Diagnosis for Emergency Department Visits by Age and Gender (\%), BKHB 2014 (continued)

\begin{tabular}{|c|c|c|c|}
\hline Age / Gender & ICD-10 Diagnosis Code & $\begin{array}{c}\text { Number of } \\
\text { Diagnosis }\end{array}$ & $\%$ \\
\hline \multicolumn{2}{|c|}{ J03 - Acute tonsillitis } & 737 & 1.61 \\
\hline \multicolumn{2}{|c|}{ R10 - Abdominal and pelvic pain } & 678 & 1.48 \\
\hline \multicolumn{2}{|c|}{ R05 - Cough } & 669 & 1.46 \\
\hline \multicolumn{2}{|c|}{$\begin{array}{l}\text { Z00.0-Encounter for general adult medical } \\
\text { examination }\end{array}$} & 602 & 1.32 \\
\hline \multicolumn{2}{|c|}{ R07.3 - Other chest pain } & 576 & 1.26 \\
\hline \multicolumn{2}{|c|}{ W83 - Other specified threats to breathing } & 531 & 1.16 \\
\hline \multicolumn{2}{|c|}{ Other diagnoses } & 19.629 & 42.98 \\
\hline \multicolumn{2}{|c|}{ 75+ Years / Male } & 33.154 & 100.00 \\
\hline \multicolumn{2}{|c|}{ R52 - Pain. unspecified } & 1.836 & 5.54 \\
\hline \multicolumn{2}{|c|}{ R07.4-Pain in chest. unspecified } & 1.755 & 5.29 \\
\hline \multicolumn{2}{|c|}{$\begin{array}{l}\text { R10.4- Other and unspecified abdominal } \\
\text { pain }\end{array}$} & 1.431 & 4.32 \\
\hline \multicolumn{2}{|c|}{ I10-Essential (primary) hypertension } & 1.326 & 4.00 \\
\hline \multicolumn{2}{|c|}{ R11 - Nausea and vomiting } & 1.274 & 3.84 \\
\hline \multicolumn{2}{|c|}{ W84-Unspecified threat to breathing } & 1.183 & 3.57 \\
\hline \multicolumn{2}{|c|}{ R53 - Malaise and fatigue } & 1.072 & 3.23 \\
\hline \multicolumn{2}{|c|}{$\begin{array}{l}\text { J06.9-Acute upper respiratory infection. } \\
\text { unspecified }\end{array}$} & 1.039 & 3.13 \\
\hline \multicolumn{2}{|c|}{ R42 - Dizziness and giddiness } & 750 & 2.26 \\
\hline \multicolumn{2}{|c|}{ W19-Unspecified fall } & 665 & 2.01 \\
\hline \multicolumn{2}{|c|}{$\begin{array}{l}\text { W01 - Fall on same level from slipping. } \\
\text { tripping and stumbling }\end{array}$} & 588 & 1.77 \\
\hline \multicolumn{2}{|c|}{ R06.0 - Dispne } & 561 & 1.69 \\
\hline \multicolumn{2}{|c|}{ J02 - Acute pharyngitis } & 548 & 1.65 \\
\hline \multicolumn{2}{|c|}{$\begin{array}{l}\text { N39.0 - Urinary tract infection. site not } \\
\text { specified }\end{array}$} & 544 & 1.64 \\
\hline \multicolumn{2}{|c|}{ J03 - Acute tonsillitis } & 537 & 1.62 \\
\hline \multicolumn{2}{|c|}{$\begin{array}{l}\text { Z00.0-Encounter for general adult medical } \\
\text { examination }\end{array}$} & 525 & 1.58 \\
\hline \multicolumn{2}{|c|}{ R07.3 - Other chest pain } & 521 & 1.57 \\
\hline \multicolumn{2}{|c|}{ R10 - Abdominal and pelvic pain } & 488 & 1.47 \\
\hline \multicolumn{2}{|c|}{ M79.1 - Myalgia } & 466 & 1.41 \\
\hline \multicolumn{2}{|c|}{ R06 - Abnormalities of breathing } & 465 & 1.40 \\
\hline \multicolumn{2}{|c|}{ Other diagnoses } & 15.580 & 46.99 \\
\hline
\end{tabular}


Table 40. Number and Distribution of Emergency Department Visits Related to External causes of morbidity and mortality (\%). BKHB 2014

\begin{tabular}{|l|c|c|c|}
\hline & $\begin{array}{c}\text { Number } \\
\text { of Visits }\end{array}$ & $\%$ & $\%$ \\
\hline All Hospitals & 190.306 & 100.00 & \\
\hline Teaching Hospitals & 153.378 & 80.60 & 100.00 \\
\hline Okmeydanı & 77.728 & 40.84 & 50.68 \\
\hline Şişli Hamidiye Etfal & 39.714 & 20.87 & 25.89 \\
\hline GOP Taksim & 35.936 & 18.88 & 23.43 \\
\hline Secondary Care Hospitals & 36.928 & 19.40 & 100.00 \\
\hline Eyüp & 12.115 & 6.37 & 32.81 \\
\hline İstinye & 14.000 & 7.36 & 37.91 \\
\hline Kâğıthane & 5.925 & 3.11 & 16.04 \\
\hline Sarıyer İsmail Akgün & 4.888 & 2.57 & 13.24 \\
\hline
\end{tabular}

Table 41. Number and Distribution of Specific Diagnosis Related to External causes of morbidity and mortality Visits (\%). BKHB 2014

\begin{tabular}{|c|c|c|}
\hline ICD 10 Code & $\begin{array}{l}\text { Number of } \\
\text { Diagnosis }\end{array}$ & $\%$ \\
\hline $\begin{array}{l}\text { W01 - Fall on same level from slipping. tripping } \\
\text { and stumbling }\end{array}$ & 51.533 & 26.90 \\
\hline W19- Unspecified fall & 42.475 & 22.17 \\
\hline $\begin{array}{l}\text { W51 - Accidental striking against or bumped } \\
\text { into by another person }\end{array}$ & 15.350 & 8.01 \\
\hline W84 - Unspecified threat to breathing & 14.230 & 7.43 \\
\hline Y35 - Legal intervention & 12.686 & 6.62 \\
\hline $\begin{array}{l}\text { W22 - Striking against or struck by other } \\
\text { objects }\end{array}$ & 7.641 & 3.99 \\
\hline W83 - Other specified threats to breathing & 5.329 & 2.78 \\
\hline W25 - Contact with sharp glass & 5.181 & 2.70 \\
\hline $\begin{array}{l}\text { W45 - Foreign body or object entering through } \\
\text { skin }\end{array}$ & 3.920 & 2.05 \\
\hline W54 - Contact with dog & 3.635 & 1.90 \\
\hline $\begin{array}{l}\text { W57 - Bitten or stung by nonvenomous insect } \\
\text { and other nonvenomous arthropods }\end{array}$ & 3.464 & 1.81 \\
\hline $\begin{array}{l}\text { W18-Other slipping. tripping and stumbling } \\
\text { and falls }\end{array}$ & 3.313 & 1.73 \\
\hline $\begin{array}{l}\text { X44 - Accidental poisoning by and exposure } \\
\text { to other and unspecified drugs. medicaments } \\
\text { and biological substances }\end{array}$ & 3.074 & 1.60 \\
\hline $\begin{array}{l}\text { Y28-Contact with sharp object. undetermined } \\
\text { intent }\end{array}$ & 3.053 & 1.59 \\
\hline $\begin{array}{l}\text { V09.3 - Pedestrian injured in unspecified traffic } \\
\text { accident }\end{array}$ & 2.070 & 1.08 \\
\hline W26 - Contact with knife. sword or dagger & 1.553 & 0.81 \\
\hline $\begin{array}{l}\text { V49.5 - Passenger injured in collision with other } \\
\text { and unspecified motor vehicles in traffic accident }\end{array}$ & 1.022 & 0.53 \\
\hline $\begin{array}{l}\text { W50 - Accidental hit. strike. kick. twist. bite or } \\
\text { scratch by another person }\end{array}$ & 975 & 0.51 \\
\hline $\begin{array}{l}\text { W23 - Caught. crushed. jammed or pinched } \\
\text { in or between objects }\end{array}$ & 890 & 0.46 \\
\hline W55 - Contact with other mammals & 591 & 0.31 \\
\hline Other diagnoses & 9.589 & 5.01 \\
\hline
\end{tabular}


Table 42. Number and Distribution of Emergency Department Visits Related to External causes of morbidity and mortality by Age and Gender (\%). BKHB 2014

\begin{tabular}{|c|c|c|c|}
\hline & Number of Visits & \multicolumn{2}{|c|}{$\%$} \\
\hline Total & 190.306 & & 100.00 \\
\hline Female & & 73.298 & 38.52 \\
\hline Male & & 117.008 & 61.48 \\
\hline Under 15 Years & 41.736 & 21.93 & 100.00 \\
\hline Under 1 Year & 816 & 0.43 & 1.96 \\
\hline 1-4 Years & 13.425 & 7.05 & 32.17 \\
\hline 5-14 Years & 27.495 & 14.45 & 65.88 \\
\hline 15-24 Years & 40.590 & & 21.33 \\
\hline 25-44 Years & 63.182 & & 33.20 \\
\hline 45-64 Years & 29.152 & & 15.32 \\
\hline 65 Years and Over & 15.646 & 8.22 & 100.00 \\
\hline $65-74$ Years & 7.725 & 4.06 & 49.37 \\
\hline 75 Years and Over & 7.921 & 4.16 & 50.63 \\
\hline \multicolumn{4}{|l|}{ Gender and Age } \\
\hline Female & 73.298 & & 100.00 \\
\hline Under 15 Years & 15.698 & 21.42 & 100.00 \\
\hline Under 1 Year & 378 & 0.52 & 2.41 \\
\hline 1-4 Years & 5.710 & 7.79 & 36.37 \\
\hline 5-14 Years & 9.610 & 13.11 & 61.22 \\
\hline 15-24 Years & 12.226 & & 16.68 \\
\hline 25-44 Years & 22.682 & & 30.94 \\
\hline 45-64 Years & 13.955 & & 19.04 \\
\hline 65 Years and Over & 8.737 & 11.92 & 100.00 \\
\hline 65-74 Years & 4.051 & 5.53 & 46.37 \\
\hline 75 Years and Over & 4.686 & 6.39 & 53.63 \\
\hline Male & 117.008 & & 100.00 \\
\hline Under 15 Years & 26.038 & 22.25 & 100.00 \\
\hline Under 1 Year & 438 & 0.37 & 1.68 \\
\hline 1-4 Years & 7.715 & 6.59 & 29.63 \\
\hline 5-14 Years & 17.885 & 15.29 & 68.69 \\
\hline $15-24$ Years & 28.364 & \multicolumn{2}{|l|}{24.24} \\
\hline 25-44 Years & 40.500 & \multicolumn{2}{|l|}{34.61} \\
\hline 45-64 Years & 15.197 & \multicolumn{2}{|l|}{12.99} \\
\hline 65 Years and Over & 6.909 & 5.90 & 100.00 \\
\hline 65-74 Years & 3.674 & 3.14 & 53.18 \\
\hline 75 Years and Over & 3.235 & 2.76 & 46.82 \\
\hline
\end{tabular}

Table 43. 10 Leading Diagnosis Related to External causes of morbidity and mortality by Age (\%). BKHB 2014

\begin{tabular}{|c|c|c|c|}
\hline Age & ICD-10 Diagnosis Code & $\begin{array}{l}\text { Number of } \\
\text { Diagnosis }\end{array}$ & $\%$ \\
\hline \multicolumn{2}{|c|}{ 0-14 Years } & 42.007 & 100.00 \\
\hline & $\begin{array}{l}\text { W01 - Fall on same level from slipping. } \\
\text { tripping and stumbling }\end{array}$ & 16.545 & 39.39 \\
\hline & W19- Unspecified fall & 13.908 & 33.11 \\
\hline & $\begin{array}{l}\text { W22 - Striking against or struck by other } \\
\text { objects }\end{array}$ & 2.246 & 5.35 \\
\hline & $\begin{array}{l}\text { W18-Other slipping. tripping and stumbling } \\
\text { and falls }\end{array}$ & 1.197 & 2.85 \\
\hline & $\begin{array}{l}\text { W57 - Bitten or stung by nonvenomous } \\
\text { insect and other nonvenomous arthropods }\end{array}$ & 1.042 & 2.48 \\
\hline & W25 - Contact with sharp glass & 952 & 2.27 \\
\hline & $\begin{array}{l}\text { W45 - Foreign body or object entering } \\
\text { through skin }\end{array}$ & 817 & 1.94 \\
\hline & $\begin{array}{l}\text { X44 - Accidental poisoning by and exposure } \\
\text { to other and unspecified drugs. medicaments } \\
\text { and biological substances }\end{array}$ & 602 & 1.43 \\
\hline & $\begin{array}{l}\text { W51 - Accidental striking against or bumped } \\
\text { into by another person }\end{array}$ & 566 & 1.35 \\
\hline & W54-Contact with dog & 560 & 1.33 \\
\hline & Other diagnoses & 3.572 & 8.50 \\
\hline \multicolumn{2}{|c|}{ 15-64 Years } & 133842 & 100.00 \\
\hline & $\begin{array}{l}\text { W01 - Fall on same level from slipping. } \\
\text { tripping and stumbling }\end{array}$ & 31.640 & 23.64 \\
\hline & W19- Unspecified fall & 25.047 & 18.71 \\
\hline & $\begin{array}{l}\text { W51 - Accidental striking against or bumped } \\
\text { into by another person }\end{array}$ & 14.606 & 10.91 \\
\hline & Y35 - Legal intervention & 12.464 & 9.31 \\
\hline & W84 - Unspecified threat to breathing & 8.693 & 6.49 \\
\hline & $\begin{array}{l}\text { W22 - Striking against or struck by other } \\
\text { objects }\end{array}$ & 5.167 & 3.86 \\
\hline & W25 - Contact with sharp glass & 4.124 & 3.08 \\
\hline & W83 - Other specified threats to breathing & 3.137 & 2.34 \\
\hline & $\begin{array}{l}\text { W45 - Foreign body or object entering } \\
\text { through skin }\end{array}$ & 2.980 & 2.23 \\
\hline & W54 - Contact with dog & 2.894 & 2.16 \\
\hline & Other diagnoses & 23.090 & 17.25 \\
\hline \multicolumn{2}{|c|}{$65+$ Years } & 15.725 & 100.00 \\
\hline & W84 - Unspecified threat to breathing & 4.983 & 31.69 \\
\hline & W19-Unspecified fall & 3.520 & 22.38 \\
\hline & $\begin{array}{l}\text { W01 - Fall on same level from slipping. } \\
\text { tripping and stumbling }\end{array}$ & 3.348 & 21.29 \\
\hline & W83 - Other specified threats to breathing & 1.924 & 12.24 \\
\hline & $\begin{array}{l}\text { W22 - Striking against or struck by other } \\
\text { objects }\end{array}$ & 228 & 1.45 \\
\hline
\end{tabular}


Table 43. 10 Leading Diagnosis Related to External causes of morbidity and mortality by Age (\%). BKHB 2014 (continued)

\begin{tabular}{|c|c|c|c|}
\hline Age & ICD-10 Diagnosis Code & $\begin{array}{l}\text { Number of } \\
\text { Diagnosis }\end{array}$ & $\%$ \\
\hline \multicolumn{2}{|c|}{$\begin{array}{l}\text { W51 - Accidental striking against or } \\
\text { bumped into by another person }\end{array}$} & 178 & 1.13 \\
\hline \multicolumn{2}{|c|}{$\begin{array}{l}\text { X44-Accidental poisoning by and exposure } \\
\text { to other and unspecified drugs. medicaments } \\
\text { and biological substances }\end{array}$} & 156 & 0.99 \\
\hline \multicolumn{2}{|c|}{$\begin{array}{l}\text { V09.3 - Pedestrian injured in unspecified } \\
\text { traffic accident }\end{array}$} & 134 & 0.85 \\
\hline \multicolumn{2}{|c|}{$\begin{array}{l}\text { W45 - Foreign body or object entering } \\
\text { through skin }\end{array}$} & 123 & 0.78 \\
\hline \multicolumn{2}{|c|}{ Other diagnoses } & 950 & 6.04 \\
\hline
\end{tabular}

Table 44. Number and Distribution of Tests Ordered in Emergency Department Visits, BKHB 2014

\begin{tabular}{|c|c|c|}
\hline Type of Test & Number of Tests & $\%$ \\
\hline All Tests & $4,607,834$ & 100.00 \\
\hline Complete Blood Count & 330,212 & 7.17 \\
\hline Creatinine & 243,289 & 5.28 \\
\hline Blood Urea Nitrogen & 242,259 & 5.26 \\
\hline $\mathrm{Na}$ & 238,507 & 5.18 \\
\hline Potassium K & 238,320 & 5.17 \\
\hline Glucose & 237,623 & 5.16 \\
\hline AST & 235,127 & 5.10 \\
\hline $\mathrm{Ca}$ & 227,775 & 4.94 \\
\hline ALT & 225,015 & 4.88 \\
\hline $\mathrm{Cl}$ & 201,862 & 4.38 \\
\hline Total direct bilirubin & 199,247 & 4.32 \\
\hline Amylase & 166,022 & 3.60 \\
\hline LDH & 151,047 & 3.28 \\
\hline Urinalaysis & 147,038 & 3.19 \\
\hline CK & 118,812 & 2.58 \\
\hline CK-MB Mass & 102,547 & 2.23 \\
\hline CRP. turbidimetric & 100,416 & 2.18 \\
\hline CRP. nephelometric & 98,006 & 2.13 \\
\hline GGT & 96,840 & 2.10 \\
\hline Troponin I & 91,483 & 1.99 \\
\hline Acid hemolysin test (Ham test) & 88,626 & 1.92 \\
\hline Albumin & 86,632 & 1.88 \\
\hline Alkaline Phosphatase & 84,026 & 1.82 \\
\hline Prothrombin Time (Coagulometric) & 79,914 & 1.73 \\
\hline APTT & 77,208 & 1.68 \\
\hline Lipase & 62,084 & 1.35 \\
\hline Troponin T & 47,050 & 1.02 \\
\hline Magnesium & 46,799 & 1.02 \\
\hline Arterial Blood Gases & 45,613 & 0.99 \\
\hline CK-MB & 44,626 & 0.97 \\
\hline Other & 253,809 & 5.51 \\
\hline
\end{tabular}


Table 45. Number and Distribution of Tests Ordered in Emergency Department Visits, BKHB Teaching Hospitals 2014

\begin{tabular}{|c|c|c|}
\hline Type of Test & Number of Tests & $\%$ \\
\hline All Tests & $4,235,045$ & 100.00 \\
\hline Complete Blood Count & 272,057 & 6.42 \\
\hline Creatinine & 224,159 & 5.29 \\
\hline Blood Urea Nitrogen & 224,081 & 5.29 \\
\hline $\mathrm{Na}$ & 220,053 & 5.20 \\
\hline K & 219,791 & 5.19 \\
\hline Glucose & 218,741 & 5.17 \\
\hline AST & 215,187 & 5.08 \\
\hline $\mathrm{Ca}$ & 213,837 & 5.05 \\
\hline ALT & 205,131 & 4.84 \\
\hline Total direct bilirubin & 190,472 & 4.50 \\
\hline $\mathrm{Cl}$ & 188,663 & 4.45 \\
\hline Amylase & 162,946 & 3.85 \\
\hline $\mathrm{LDH}$ & 147,394 & 3.48 \\
\hline Urinalaysis & 130,866 & 3.09 \\
\hline CK & 111,164 & 2.62 \\
\hline GGT & 95,897 & 2.26 \\
\hline CRP, nephelometric & 94,949 & 2.24 \\
\hline Acid hemolysin test (Ham test) & 88,626 & 2.09 \\
\hline CRP, turbidimetric & 88,210 & 2.08 \\
\hline Albumin & 85,596 & 2.02 \\
\hline CK-MB Mass & 84,529 & 2.00 \\
\hline Alcaline Phosphatase & 81,742 & 1.93 \\
\hline Prothrombin Time (Coagulometric) & 78,139 & 1.85 \\
\hline APTT & 76,238 & 1.80 \\
\hline Troponin I & 69,349 & 1.64 \\
\hline Lipase & 61,785 & 1.46 \\
\hline Troponin T & 47,050 & 1.11 \\
\hline Magnesium & 46,581 & 1.10 \\
\hline Arterial Blood Gases & 45,464 & 1.07 \\
\hline CK-MB & 36,914 & 0.87 \\
\hline Other & 209,434 & 4.95 \\
\hline
\end{tabular}

Table 46. Number and Distribution of Tests Ordered in Emergency Department Visits, BKHB Secondary Care Hospitals 2014

\begin{tabular}{|l|c|c|}
\hline Type of Test & Number of Tests & $\%$ \\
\hline All Tests & 372,789 & 100.00 \\
\hline Complete Blood Count & 58,155 & 15.60 \\
\hline Troponin I & 22,134 & 5.94 \\
\hline AST & 19,940 & 5.35 \\
\hline ALT & 19,884 & 5.33 \\
\hline Creatinine & 19,130 & 5.13 \\
\hline Glucose & 18,882 & 5.07 \\
\hline Potassium & 18,529 & 4.97 \\
\hline Na & 18,454 & 4.95 \\
\hline Blood Urea Nitrogen & 18,178 & 4.88 \\
\hline CK-MB Mass & 18,018 & 4.83 \\
\hline Urine Dipstick Analysis & 17,105 & 4.59 \\
\hline Microscopic urinalysis & 16,172 & 4.34 \\
\hline Ca & 13,938 & 3.74 \\
\hline Cl & 13,199 & 3.54 \\
\hline CRP, nephelometric & 12,206 & 3.27 \\
\hline Total direct bilirubin & 8,775 & 2.35 \\
\hline CK-MB & 7,712 & 2.07 \\
\hline CK & 7,648 & 2.05 \\
\hline Miyoglobin & 5,453 & 1.46 \\
\hline LDH & 3,653 & 0.98 \\
\hline Amylase & 3,076 & 0.83 \\
\hline CRP, turbidimetric & 3,057 & 0.82 \\
\hline Beta-hCG (Total hCG) & 2,893 & 0.78 \\
\hline Alkaline Phosphatase & $1,287,747$ & 0.61 \\
\hline Prothrombin Time (Coagulometric) & 1,775 & 0.48 \\
\hline Cholesterol & 1,629 & 0.44 \\
\hline Trigliserid & 1,609 & 0.43 \\
\hline HDL cholesterol & 1,600 & 0.43 \\
\hline LDL cholesterol & & \\
\hline ASO (Nephelometric) & 3.97 \\
\hline Other & 1,36 \\
\hline
\end{tabular}


Table 47. Number and Distribution of Imaging Tests Ordered in Emergency Department Visits, BKHB 2014

\begin{tabular}{|l|c|c|}
\hline Type of Imaging & $\begin{array}{c}\text { Number of } \\
\text { Imaging }\end{array}$ & $\%$ \\
\hline Any Imaging & 897,520 & 100.00 \\
\hline X-ray & 584,576 & 65.13 \\
\hline Computed Tomography Scan & 178,773 & 19.92 \\
\hline Ultrasound & 92,966 & 10.36 \\
\hline Magnetic Resonance Imaging Scan & 24,816 & 2.76 \\
\hline Color Doppler & 15,972 & 1.78 \\
\hline Other Imaging & 417 & 0.05 \\
\hline
\end{tabular}

Table 48. Number and Distribution of Imaging Tests Ordered in Emergency Department Visits, BKHB Teaching Hospitals 2014

\begin{tabular}{|l|c|c|}
\hline Type of Imaging & $\begin{array}{c}\text { Number of } \\
\text { Imaging }\end{array}$ & $\%$ \\
\hline Any Imaging & 784,398 & 100.00 \\
\hline X-ray & 484,033 & 61.71 \\
\hline Computed Tomography Scan & 173,798 & 22.16 \\
\hline Ultrasound & 88,074 & 11.23 \\
\hline Magnetic Resonance Imaging Scan & 23,206 & 2.96 \\
\hline Color Doppler & 14,971 & 1.91 \\
\hline Other Imaging & 316 & 0.04 \\
\hline
\end{tabular}

Table 49. Number and Distribution of Imaging Tests Ordered in Emergency Department Visits, BKHB Secondary Care Hospitals 2014

\begin{tabular}{|l|c|c|}
\hline Type of Imaging & $\begin{array}{c}\text { Number of } \\
\text { Imaging }\end{array}$ & $\%$ \\
\hline Any Imaging & 113,122 & 100.00 \\
\hline X-ray & 100,543 & 88.88 \\
\hline Computed Tomography Scan & 4,975 & 4.40 \\
\hline Ultrasound & 4,892 & 4.32 \\
\hline Magnetic Resonance Imaging Scan & 1,610 & 1.42 \\
\hline Color Doppler & 1,001 & 0.88 \\
\hline Other Imaging & 101 & 0.09 \\
\hline
\end{tabular}

Table 50. Number and Distribution of the Imaging Tests by body part, BKHB 2014

\begin{tabular}{|c|c|c|}
\hline Type of Imaging & $\begin{array}{l}\text { Number of } \\
\text { Imaging }\end{array}$ & $\%$ \\
\hline X-ray & 584,576 & 100.00 \\
\hline Joint X-ray (double site ) single joint & 207,661 & 35.52 \\
\hline Chest X-ray P.A. (single site) & 148,925 & 25.48 \\
\hline Abdominal X-ray & 98,802 & 16.90 \\
\hline Chest X-ray (double site) & 29,259 & 5.01 \\
\hline Joint X-ray (double site ) with comparison & 18,946 & 3.24 \\
\hline All Other X-ray & 80,983 & 13.85 \\
\hline Computed Tomography Scan (CT) & 178,773 & 100.00 \\
\hline CT. Cranial & 70,401 & 39.38 \\
\hline CT. Thorax & 22,391 & 12.52 \\
\hline CT. Extremity $(20-50 \mathrm{~cm})$ & 20,197 & 11.30 \\
\hline CT. Cranial (Axial+Coronal) & 16,308 & 9.12 \\
\hline CT. Abdomen. Lower quadrant & 10,037 & 5.61 \\
\hline All Other CT & 39,439 & 22.06 \\
\hline Ultrasound (USG) & 92,966 & 100.00 \\
\hline Abdominal USG & 41,367 & 44.50 \\
\hline Ultrasound. Other & 34,135 & 36.72 \\
\hline Ultrasound. General & 4,611 & 4.96 \\
\hline Renal USG & 4,389 & 4.72 \\
\hline Scrotal USG & 1,530 & 1.65 \\
\hline All Other USG & 6,934 & 7.46 \\
\hline Magnetic Resonance Imaging Scan (MRI) & 24,816 & 100.00 \\
\hline MRI. Diffusion & 13,079 & 52.70 \\
\hline MRI. Cranial & 2,690 & 10.84 \\
\hline MRI. Single joint & 2,437 & 9.82 \\
\hline MRI of the Lumbar Spine & 2,293 & 9.24 \\
\hline MRI of the Cervical Spine & 964 & 3.88 \\
\hline All Other MRI & 3,353 & 13.51 \\
\hline Color Doppler & 15,971 & 100.00 \\
\hline $\begin{array}{l}\text { Lower extremity venous doppler. single } \\
\text { site }\end{array}$ & 4,431 & 27.74 \\
\hline Fetal biometry and biophysical profile & 3,081 & 19.29 \\
\hline $\begin{array}{l}\text { Lower extremity arterial doppler. single } \\
\text { site }\end{array}$ & 2,870 & 17.97 \\
\hline Pelvic Color Doppler US & 1,246 & 7.80 \\
\hline Obstetric Color Doppler US & 1,241 & 7.77 \\
\hline All Other Color Doppler & 3,102 & 19.42 \\
\hline
\end{tabular}


Table 51. Number and Distribution of 20 Leading Procedures Ordered in Emergency Department Visits, BKHB 2014

\begin{tabular}{|l|c|c|}
\hline Type of Procedure & $\begin{array}{c}\text { Number of } \\
\text { Procedures }\end{array}$ & $\%$ \\
\hline All Procesures & $1,548,308$ & 100.00 \\
\hline Intramuscular injection & 791,342 & 51.11 \\
\hline Intravenous catheter insertion & 187,596 & 12.12 \\
\hline Electrocardiogram & 131,666 & 8.50 \\
\hline Intravenous injection & 109,347 & 7.06 \\
\hline Intravenous drug therapy & 66,357 & 4.29 \\
\hline Wound dressing & 64,408 & 4.16 \\
\hline Nebulizer therapy & 49,143 & 3.17 \\
\hline Oxygen inhalation therapy & 36,040 & 2.33 \\
\hline Moniterization & 24,196 & 1.56 \\
\hline Subcutaneous injection & 19,288 & 1.25 \\
\hline Suturing and staples & 16,509 & 1.07 \\
\hline Enema administration & 12,854 & 0.83 \\
\hline Follow up of blood gases & 11,056 & 0.71 \\
\hline Bladder catheter & 6,341 & 0.41 \\
\hline Local anesthesia & 5,294 & 0.34 \\
\hline Wound debridement & 3,692 & 0.24 \\
\hline Transfusion of blood or blood products & 1,684 & 0.24 \\
\hline Removal of sutures & 4,041 & 0.26 \\
\hline Burn care & & 0.13 \\
\hline Nasogastric intubation & 0.12 \\
\hline Other & 2,086 & 0.09 \\
\hline
\end{tabular}

Table 52. Number and Distribution of 20 Leading Procedures Ordered in Emergency Department Visits, BKHB Teaching Hospitals 2014

\begin{tabular}{|l|c|c|}
\hline Type of Procedure & $\begin{array}{c}\text { Number of } \\
\text { Procedures }\end{array}$ & $\%$ \\
\hline All Procedures & 938,987 & 100.00 \\
\hline Intramuscular injection & 375,955 & 40.04 \\
\hline Intravenous catheter insertion & 143,999 & 15.34 \\
\hline Electrocardiogram & 102,025 & 10.87 \\
\hline Intravenous injection & 100,382 & 10.69 \\
\hline Intravenous drug therapy & 48,974 & 5.22 \\
\hline Nebulizer therapy & 39,261 & 4.18 \\
\hline Moniterization & 22,414 & 2.39 \\
\hline Oxygen inhalation therapy & 19,488 & 2.08 \\
\hline Wound dressing & 17,769 & 1.89 \\
\hline Subcutaneous injection & 17,532 & 1.87 \\
\hline Enema administration & 12,811 & 1.36 \\
\hline Follow up of blood gases & 11,007 & 1.17 \\
\hline Suturing and staples & 9,619 & 1.02 \\
\hline Bladder catheter & 5,384 & 0.57 \\
\hline Transfusion of blood or blood products & 3,679 & 0.39 \\
\hline Local anesthesia & 2,903 & 0.31 \\
\hline Nasogastric intubation & 1,138 & 0.12 \\
\hline Removal of sutures & 1,134 & 0.12 \\
\hline Burn care & & 0.12 \\
\hline Wound debridement & 090 \\
\hline Other & 0.08 \\
\hline
\end{tabular}


Table 53. Number and Distribution of 20 Leading Procedures Ordered in Emergency Department Visits, BKHB Secondary Care Hospitals 2014

\begin{tabular}{|l|c|c|}
\hline Type of Procedure & $\begin{array}{c}\text { Number of } \\
\text { Procedures }\end{array}$ & $\%$ \\
\hline All Procedures & 609,321 & 100.00 \\
\hline Intramuscular injection & 415,387 & 68.17 \\
\hline Wound dressing & 46,639 & 7.65 \\
\hline Intravenous catheter insertion & 43,597 & 7.16 \\
\hline Electrocardiogram & 29,641 & 4.86 \\
\hline Intravenous drug therapy & 17,383 & 2.85 \\
\hline Oxygen inhalation therapy & 16,552 & 2.72 \\
\hline Nebulizer therapy & 9,882 & 1.62 \\
\hline Intravenous injection & 8,965 & 1.47 \\
\hline Suturing and staples & 6,890 & 1.13 \\
\hline Incision and drainage & 2,966 & 0.49 \\
\hline Local anesthesia & 2,391 & 0.39 \\
\hline Moniterization & 1,782 & 0.29 \\
\hline Subcutaneous injection & 1,756 & 0.29 \\
\hline Bladder catheter & 957 & 0.16 \\
\hline Removal of sutures & 952 & 0.16 \\
\hline Burn care & 3323 & 0.14 \\
\hline Abscess or hematoma drainage. superficial & 741 & 0.12 \\
\hline Burn debridement. mid size & 0.05 \\
\hline Burn debridement. small size & 317 & 0.05 \\
\hline Nasogastric intubation & 0.17 \\
\hline Other & 385 \\
\hline
\end{tabular}

Table 54. Number and Distribution of 20 Most Frequently Administered Drugs in Emergency Department Visits, BKHB 2014

\begin{tabular}{|c|c|c|c|}
\hline Active Ingredient & Drug Category & $\begin{array}{c}\text { Number } \\
\text { Administered }\end{array}$ & $\%$ \\
\hline Total & & $1,467,000$ & 100.00 \\
\hline Diclofenac Sodium & $\begin{array}{l}\text { Antiinflammatory And } \\
\text { Antirheumatic Products. } \\
\text { Non-Steroids }\end{array}$ & 299,105 & 20.39 \\
\hline Ranitidine & $\begin{array}{l}\text { Drugs For Peptic Ulcer And } \\
\text { Gastro-Oesophageal Reflux } \\
\text { Disease (Gord) }\end{array}$ & 144,262 & 9.83 \\
\hline Metoclopramide Hcl & Propulsives & 132,986 & 9.07 \\
\hline Salbutamol & Adrenergics. Inhalants & 123,194 & 8.40 \\
\hline $\mathrm{NaCl}$ & $\begin{array}{l}\text { Blood Substitutes And } \\
\text { Perfusion Solutions }\end{array}$ & 106,622 & 7.27 \\
\hline Paracetamol & $\begin{array}{l}\text { Other Analgesics And } \\
\text { Antipyretics }\end{array}$ & 48,389 & 3.30 \\
\hline Furosemide & High-Ceiling Diuretics & 45,833 & 3.12 \\
\hline Pheniramine & $\begin{array}{l}\text { Antihistamines For } \\
\text { Systemic Use }\end{array}$ & 43,735 & 2.98 \\
\hline $\begin{array}{l}\text { Hyoscine } \\
\text { Butylbromide }\end{array}$ & $\begin{array}{l}\text { Belladonna And } \\
\text { Derivatives. Plain }\end{array}$ & 43,039 & 2.93 \\
\hline Captopril & Ace Inhibitors. Plain & 42,115 & 2.87 \\
\hline $\begin{array}{l}\text { Methylprednisolone } \\
\text { Sodium Succinate }\end{array}$ & $\begin{array}{l}\text { Corticosteroids For Systemic } \\
\text { Use. Plain }\end{array}$ & 35,578 & 2.43 \\
\hline Omeprazole & $\begin{array}{l}\text { Drugs For Peptic Ulcer And } \\
\text { Gastro-Oesophageal } \\
\text { Reflux Disease (Gord) }\end{array}$ & 29,333 & 2.00 \\
\hline Metamizole Sodium & $\begin{array}{l}\text { Other Analgesics And } \\
\text { Antipyretics }\end{array}$ & 27,987 & 1.91 \\
\hline Thiocolchicoside & $\begin{array}{l}\text { Muscle Relaxants. } \\
\text { Centrally Acting Agents }\end{array}$ & 21,403 & 1.46 \\
\hline $\begin{array}{l}\text { Fluticasone } \\
\text { Propionate }\end{array}$ & $\begin{array}{l}\text { Other Drugs For Obstructive } \\
\text { Airway Diseases. Inhalants }\end{array}$ & 20,172 & 1.38 \\
\hline $\begin{array}{l}\text { Dexketoprofen } \\
\text { Trometamol }\end{array}$ & $\begin{array}{l}\text { Antiinflammatory And } \\
\text { Antirheumatic Products. } \\
\text { Non-Steroids }\end{array}$ & 19,213 & 1.31 \\
\hline \begin{tabular}{|l|} 
Ipratropium Bromide \\
Monohydrate + \\
Salbutamol Sulfate
\end{tabular} & Adrenergics. Inhalants & 18,864 & 1.29 \\
\hline Adrenaline & $\begin{array}{l}\text { Cardiac Stimulants } \\
\text { Excluding Cardiac } \\
\text { Glycosides }\end{array}$ & 16,797 & 1.14 \\
\hline Dexamethasone & $\begin{array}{l}\text { Corticosteroids For } \\
\text { Systemic Use. Plain }\end{array}$ & 13,328 & 0.91 \\
\hline Acetylcysteine & $\begin{array}{l}\text { Expectorants. Excl. } \\
\text { Combinations With Cough } \\
\text { Suppressants }\end{array}$ & 12,615 & 0.86 \\
\hline Other & - & 222,431 & 15.16 \\
\hline
\end{tabular}


Table 55. Number and Distribution of 20 Most Frequently Electronically Prescribed Drugs in Emergency Department Visits, BKHB 2014

\begin{tabular}{|c|c|c|c|}
\hline Active Ingredient & Drug Category & $\begin{array}{c}\text { Number } \\
\text { Administered }\end{array}$ & $\%$ \\
\hline Total & - & 709,681 & 100.00 \\
\hline Paracetamol & $\begin{array}{l}\text { Other Analgesics And } \\
\text { Antipyretics }\end{array}$ & 50,130 & 7.06 \\
\hline $\begin{array}{l}\text { Amoxicillin + } \\
\text { Clavulanic Acid }\end{array}$ & $\begin{array}{l}\text { Beta-Lactam } \\
\text { Antibacterials. Penicillins }\end{array}$ & 43,715 & 6.16 \\
\hline $\begin{array}{l}\text { Benzydamine } \mathrm{Hcl}+ \\
\text { Chlorhexidine } \\
\text { Glukonat }\end{array}$ & $\begin{array}{l}\text { Stomatological } \\
\text { Preparations }\end{array}$ & 26,007 & 3.66 \\
\hline Ibuprofen & $\begin{array}{l}\text { Antiinflammatory And } \\
\text { Antirheumatic Products. } \\
\text { Non-Steroids }\end{array}$ & 21,384 & 3.01 \\
\hline $\begin{array}{l}\text { Ibuprofen }+ \\
\text { Pseudoephedrine } \\
\text { Hcl }\end{array}$ & $\begin{array}{l}\text { Antiinflammatory And } \\
\text { Antirheumatic Products. } \\
\text { Non-Steroids }\end{array}$ & 21,124 & 2.98 \\
\hline Cefprozil & $\begin{array}{l}\text { Other Beta-Lactam } \\
\text { Antibacterials }\end{array}$ & 19,954 & 2.81 \\
\hline $\begin{array}{l}\text { Dexketoprofen } \\
\text { Trometamol }\end{array}$ & $\begin{array}{l}\text { Antiinflammatory And } \\
\text { Antirheumatic Products. } \\
\text { Non-Steroids }\end{array}$ & 19,282 & 2.72 \\
\hline Etodolac & $\begin{array}{l}\text { Antiinflammatory And } \\
\text { Antirheumatic Products. } \\
\text { Non-Steroids }\end{array}$ & 18,405 & 2.59 \\
\hline Thiocolchicoside & $\begin{array}{l}\text { Muscle Relaxants. } \\
\text { Centrally Acting Agents }\end{array}$ & 13,930 & 1.96 \\
\hline Metoclopramide $\mathrm{Hcl}$ & Propulsives & 13,837 & 1.95 \\
\hline Benzydamine $\mathrm{Hcl}$ & Stomatological Preparations & 13,627 & 1.92 \\
\hline $\begin{array}{l}\text { Cephalexin } \\
\text { Monohydrate }\end{array}$ & $\begin{array}{l}\text { Other Beta-Lactam } \\
\text { Antibacterials }\end{array}$ & 12,553 & 1.77 \\
\hline Butamirate Citrate & $\begin{array}{l}\text { Cough Suppressants. Excl. } \\
\text { Combinations With } \\
\text { Expectorants }\end{array}$ & 11,308 & 1.59 \\
\hline Flurbiprofen & $\begin{array}{l}\text { Antiinflammatory And } \\
\text { Antirheumatic Products. } \\
\text { Non-Steroids }\end{array}$ & 11,189 & 1.58 \\
\hline Cefuroxime Axetil & $\begin{array}{l}\text { Other Beta-Lactam } \\
\text { Antibacterials }\end{array}$ & 11,185 & 1.58 \\
\hline Ciprofloxacin & Quinolone Antibacterials & 10,757 & 1.52 \\
\hline $\begin{array}{l}\text { Chlorpheniramine } \\
\text { Maleate + Oxolamine } \\
\text { Citrate + Parasetamol } \\
+ \text { Pseudoephedrine } \\
\text { Hcl }\end{array}$ & $\begin{array}{l}\text { Cough And Cold } \\
\text { Preparations }\end{array}$ & 9,899 & 1.39 \\
\hline Ketoprofen & $\begin{array}{l}\text { Antiinflammatory And } \\
\text { Antirheumatic Products. } \\
\text { Non-Steroids }\end{array}$ & 9,882 & 1.39 \\
\hline $\begin{array}{l}\text { Acetylcysteine + } \\
\text { Paracetamol }\end{array}$ & $\begin{array}{l}\text { Cough And Cold } \\
\text { Preparations }\end{array}$ & 9,628 & 1.36 \\
\hline Oxymetazoline $\mathrm{Hcl}$ & $\begin{array}{l}\text { Decongestants And Other } \\
\text { Nasal Preparations For } \\
\text { Topical Use }\end{array}$ & 9,286 & 1.31 \\
\hline Other Diagnoses & - & 352,599 & 49.68 \\
\hline
\end{tabular}

Table 56. Disposition of Emergency Department Visits (\%) BKHB 2014

\begin{tabular}{|l|c|c|c|c|c|}
\hline & Died & Admitted & Transferred* & Discharged & Total \\
\hline All Hospitals & 0.02 & 2.53 & 0.32 & 97.13 & 100.00 \\
\hline Teaching Hospitals & 0.02 & 3.43 & 0.35 & 96.20 & 100.00 \\
\hline Okmeydanı & 0.03 & 3.27 & 0.30 & 96.40 & 100.00 \\
\hline Şişli Hamidiye Etfal & 0.02 & 4.02 & 0.52 & 95.44 & 100.00 \\
\hline GOP Taksim & 0.01 & 2.83 & 0.20 & 96.97 & 100.00 \\
\hline $\begin{array}{l}\text { Secondary Care } \\
\text { Hospitals }\end{array}$ & 0.01 & 0.43 & 0.25 & 99.32 & 100.00 \\
\hline Eyüp & 0.001 & 0.50 & 0.19 & 99.31 & 100.00 \\
\hline İstinye & 0.00 & 0.99 & 0.38 & 98.63 & 100.00 \\
\hline Kâğıthane & 0.01 & 0.02 & 0.21 & 99.76 & 100.00 \\
\hline $\begin{array}{l}\text { Sarıyer İsmail } \\
\text { Akgün }\end{array}$ & 0.02 & 0.00 & 0.27 & 99.71 & 100.00 \\
\hline *Transfer to other hospital & & & & \\
\hline
\end{tabular}




\section{CONCLUSION}

It is one of the vital duties of healthcare workers and executives to provide access to high quality, timely and safe healthcare without financial burden for those whose health suddenly deteriorates and who needs immediate care. Therefore, it is one of our priorities to enhance and improve the emergency healthcare in our hospitals.

As the data in our survey demonstrate, most of the patients visiting the Emergency Departments do not actually need emergency care. Considering the limitations on human resources, technical and physical infrastructure, it will become more and more difficult for our emergency departments to provide safe and quality healthcare to increasing number of patients. The cautions taken by the Public Hospitals Unions and the hospital managements solve the problems to a certain extent. Policy makers should take steps for permanent and efficient solutions.

Family medicine and family physician centered system which is founded as part of Health Transformation Program has not initiated a referral mechanism yet, so usually the patients who want to see a doctor immediately can apply to any hospital. When the number of visits, the variety of diagnosis and the treatments are surveyed, it is seen that our people tend to present to the Emergency Departments for their basic healthcare needs.

In order to reduce the patient volume, to prevent inappropriate visits and to provide quality service in our Emergency Departments, the quality of primary health services must be enhanced, the patients and relatives should be educated and the number and the capacity of the healthcare staff should be improved. One of the most important reasons why the people prefer an emergency department is that they are able to get the laboratory and imaging services easier. Unfortunately the patients who apply to family physicians can't get to basic diagnostic tests such as $\mathrm{x}$-ray at the point of care. In order to solve this problem, district outpatient clinics should be widespread and family physicians should be employed in these clinics. This way, family physicians would become more trusted by the patients and the cooperation between the primary and secondary care would improve.

Another way of reducing the high patient volume will be to support the research on frequent emergency department visits which was initiated for the first time by Beyoglu Public Hospitals Union in our country. This way, we can develop national policies about the issue. Considering these types of patients can visit different hospitals for the same health problem, it is obvious that an integrated system is needed to track number of visits in different locations. When the number of visits reaches a certain point, these patients should be followed up and taken care of using case management method which should be carried out by a multidisciplinary team consisting of family physicians, nurses, psychologists and social workers.

Another major problem stated in our survey is that the patient medical records are not kept properly in our hospital information sys- tems because of the lack of qualified personnel and the deficiencies in system design. To better determine the quality and adequacy of the healthcare provided by our hospitals we need proper medical record keeping. This way, we can analyze the data and share it with the clinicians and management for better decision making.

Manual patient file recording and follow-up on paper files is not preferred because it is both inconvenient and unreliable for timely data analysis. Therefore, it is very important for the Hospital Information systems to be designed in a way that make record keeping easy and fast especially for Emergency Departments. Setting up a strong Information technology infrastructure is going to make a significant contribution on quality of healthcare and help us plan for the future.

\section{References}

1. Available at: http://www.cdc.gov/nchs/fastats/emergency-department. htm) (http://www.hscic.gov.uk/catalogue/PUB13464)

2. National Ambulatory Medical Care Survey: 2011 Emergency Department Summary Tablos.

3. Australian Hospital Statistics 2011-12 Emergency Department Care. National Ambulatory Medical Care Survey: 2011 Emergency Department Summary Tablos

4. Byrne M, Murphy AW, Plunkett PK, et al. Frequent attenders to an emergency department: a study of primary health care use, medical profile, and psychosocial characteristics. Ann Emerg Med 2003; 41: 309-18. [CrossRef]

5. Hunt KA, Weber EJ, Showstack JA, Colby DC, Callaham ML. Characteristics of frequent users of emergency departments. Ann Emerg Med 2006; 7: 1-8. [CrossRef]

6. Van der Linden $M C$, van den Brand $C L$, van der Linden $N$, Rambach $A H$ Brumsen C. Rate, characteristics, and factors associated with high emergency department utilization. Int J Emerg Med 2014; 7: 9. [CrossRef]

7. Dent A, Hunter G, Webster AP. The impact of frequent attenders on a UK emergency department. Eur J Emerg Med 2010; 17: 332-6. [CrossRef]

8. Althaus F, Stucki S, Guyot S, Trueb L, Moschetti K, Daeppen JB, Bodenmann P. Characteristics of highly frequent users of a Swiss academic emergency department: a retrospective consecutive case series. Eur J Emerg Med 2013; 20: 413-9. [CrossRef]

9. Huang JA, Tsai WC, Chen YC, Hu WH, Yang DY. Factors associated with frequent use of emergency services in a medical center. J Formos Med Assoc 2003; 102: 222-8.

10. Jelinek GA, Jiwa M, Gibson NP, Lynch AM. Frequent attenders at emergency departments: a linked-data population study of adult patients. Med J Aust 2008; 189: 552-69.

11. Doupe MB, Palatnick W, Day S, Chateau D, Soodeen RA, Burchill C, Derksen S. Frequent users of emergency departments: developing standard definitions and defining prominent risk factors. Ann Emerg Med 2012; 60: 24-32. [CrossRef]

12. Fuda KK, Immekus R. Frequent users of Massachusetts emergency departments: a statewide analysis. Ann Emerg Med 2006; 48: 9-16. [CrossRef]

13. Nunez $\mathrm{S}$, Hexdall A, Aguirre-Jaime A. Unscheduled returns to the emergency department: an outcome of medical errors, Qual Saf Health Care 2006; 15: 102-8. [CrossRef]

14. Hospital Episode Statistics: Accident and Emergency Attendances in England - 2012-13. 